\title{
13. LATE PALEOGENE (EOCENE TO OLIGOCENE) BENTHIC FORAMINIFERAL OCEANOGRAPHY OF THE GOBAN SPUR REGION, DEEP SEA DRILLING PROJECT LEG 80 ${ }^{1}$
}

\author{
Kenneth G. Miller, Woods Hole Oceanographic Institution/Massachusetts Institute of Technology, \\ Joint Program in Oceanography, Woods Hole \\ and \\ William B. Curry and D. R. Ostermann, Department of Geology and Geophysics, \\ Woods Hole Oceanographic Institution ${ }^{2}$
}

\begin{abstract}
Major benthic foraminiferal changes occurred in the late Eocene at Site 549. A Nuttallides truempyi-dominated assemblage was replaced by a buliminid assemblage ( $\sim 40-38.5 \mathrm{~m} . \mathrm{y}$. ago); this change in faunal abundance was apparently a circum-Atlantic event. The buliminid assemblage was replaced, in turn, by an assemblage dominated by stratigraphically long-ranging and bathymetrically wide-ranging taxa just below the Eocene/Oligocene boundary ( $\sim 37.5 \mathrm{~m} . \mathrm{y}$. ago). A series of late Eocene to earliest Oligocene first and last appearances of taxa accompanied these abundance changes. Similar changes in faunal abundance occurred at Site 548, but the incomplete record recovered at Site 548 prevents a firm dating of the changes. No major benthic foraminiferal changes (denoted by the extinction of Hantkenina, Cribrohantkenina, and Globorotalia cerroazulensis) were associated with the Eocene/Oligocene boundary at these sites; instead, benthic foraminiferal abundance changes, last appearances (both extinctions and local disappearances), and first appearances occurred throughout the late Eocene to earliest Oligocene interval ( $~ 40-36 \mathrm{~m} . \mathrm{y}$. ago).

Benthic foraminiferal $\delta^{18} \mathrm{O}$ increased $\sim 1.0 \%$ in the late Eocene to earliest Oligocene $(\sim 38-36.5 \mathrm{~m} . \mathrm{y}$. ago $)$ at Site 549. Most $\left(\sim 0.7 \%\right.$ ) of this increase occurred simultaneously with a $0.6 \%$ increase in benthic foraminiferal $\delta^{13} \mathrm{C}$ as a geologically rapid event in the earliest Oligocene $(\sim 36.5 \mathrm{~m} . \mathrm{y} . \mathrm{ago})$. The major benthic foraminiferal abundance change ( 40-38 m.y. ago) predates the major isotopic enrichments. A prominent seismic horizon, Reflector R4, has been noted in the Labrador Sea, Rockall, and Biscay regions, and has been dated as latest Eocene to early Oligocene. This horizon marks the onset of increased intensity of abyssal circulation associated with the initial entry of bottom water from the Norwegian-Greenland Sea and/or Arctic Ocean into the North Atlantic. The interval during which Reflector R4 was formed may encompass both the faunal and isotopic changes; the best estimate for the age of this horizon and the associated circulation change suggests that it correlates with the $\delta^{18} \mathrm{O}$ increase. Our interpretation of these data suggests that a temperature drop, decrease in age (increased $\mathrm{O}_{2}$, lowered $\mathrm{CO}_{2}$, increased $\mathrm{pH}$, hence decreased corrosiveness) of bottom water, and an increase in intensity of abyssal circulation occurred in the late Eocene to earliest Oligocene of the North Atlantic.
\end{abstract}

\section{INTRODUCTION}

The recovery of numerous Tertiary deep-sea sections by the Deep Sea Drilling Project (DSDP) has led to a rapidly expanding data base for the study of Tertiary deep-sea benthic foraminiferal assemblages which, in turn, has led to renewed interest in this group (Berggren, 1972a; Douglas, 1973; Berggren and Aubert, 1976; Resig, 1976; Boersma, 1977; Proto-Decima and Bolli, 1978; Schnitker, 1979; Boltovskoy,1980; Corliss, 1979a, 1981; Tjalsma and Lohmann, 1983; Douglas and Woodruff, 1982; Miller, 1983; Berggren and Schnitker, 1983). Comparison among these studies has been difficult owing to disagreements in taxonomy (Boltovskoy, 1980) and differences in size-fraction studies. Tjalsma and Lohmann (1983) have, however, made a detailed taxonomic revision of late Paleogene deep-sea benthic foraminifers, which now allows placement of these taxa into a standardized framework.

\footnotetext{
${ }^{1}$ Graciansky, P. C. de, Poag, C. W., et al., Init. Repts. DSDP, 80: Washington (U.S. Govt, Printing Office)

2 Addresses: (Miller, present address) Lamont-Doherty Geological Observatory of Columbia University, Palisades, NY 10964; (Curry and Ostermann) Dept. of Geology and Geophysics, Woods Hole Oceanographic Institution, Woods Hole, MA 02543.
}

Distributions of modern deep-sea benthic foraminifers correlate with water masses and properties that vary with water masses (Streeter, 1973; Schnitker, 1974; Lohmann, 1978; Corliss, 1979b; Bremer and Lohmann, 1982). Interpretations of water-mass/foraminiferal relationships have been extended to the Tertiary fossil record to determine changes in paleocirculation (Schnitker, 1979; Tjalsma and Lohmann, 1983; Douglas and Woodruff, 1982). Paleoceanographic interpretations of changes in deepsea benthic foraminiferal assemblage or isotopic composition often conflict, however. This is illustrated by disputes as to the nature, timing, and causes of late Paleogene benthic foraminiferal changes. Douglas (1973), Benson (1975), Boersma (1977), and Schnitker (1979) suggested that a major benthic turnover occurred near the Eocene/Oligocene boundary, whereas Corliss (1979b, 1981), Tjalsma (1982), and Tjalsma and Lohmann (1983) suggested more gradual or sequential changes. Benthic foraminiferal isotopic and assemblage data for both the early to middle Miocene (Blanc et al., 1980; Schnitker, 1979, 1980a,b) and the late Paleogene (Miller and Curry, 1982; Miller, 1983) have been cited as evidence for the first significant influx of bottom water into the North Atlantic from northern sources (Arctic Ocean and/or Norwegian-Greenland Sea). 
The seismic stratigraphic record provides a different type of evidence for changes in abyssal circulation. Miller and Tucholke (1983) presented a model for the development of abyssal circulation in the North Atlantic derived from seismic stratigraphic studies of the Rockall region and the southern Labrador Sea (Jones et al., 1970; Ruddiman, 1972; Roberts, 1975; Miller and Tucholke, 1983). The model suggests that an erosional episode, representing the most vigorous bottom-water flow, occurred in the latest Eocene through early Oligocene, and that subsequent depositional sequences, resulting from generally decreasing bottom-water flow (occasionally punctuated by erosional events), occurred in the late Oligocene through Neogene.

Miller (1983) used the taxonomic base of Tjalsma and Lohmann (1983) to identify late Paleogene bathyal to abyssal assemblages in the Bay of Biscay (DSDP Legs 12 and 48), and interpreted changes in assemblages, taking the abyssal circulation model into account. Miller and Curry (1982) attempted to date major benthic foraminiferal ${ }^{18} \mathrm{O}$ and ${ }^{13} \mathrm{C}$ enrichments in the Bay of Biscay and to relate them to changes in abyssal circulation and assemblages. Unfortunately, the stratigraphic record recovered in the Bay of Biscay before Leg 80 was not complete enough to resolve firmly the timing of major benthic foraminiferal isotopic and assemblage changes and their relation to the circulation model.

This study analyzes changes in benthic foraminiferal assemblages from the Eocene through Oligocene of Site
548 (1256 m present depth), Site 549 (2533 m present depth), and Site 550 (4432 m present depth), and presents benthic foraminiferal $\delta^{18} \mathrm{O}$ and $\delta^{13} \mathrm{C}$ analyses from Site 549. The Eocene to Oligocene chronostratigraphic record recovered in the North Atlantic before Leg 80 is punctuated by numerous hiatuses (Moore et al., 1978; Miller and Tucholke, 1983), which prevented delineation of isotopic and faunal changes in this part of the ocean. The relatively complete record recovered at Site 549 allows a determination of the faunal and isotopic changes across the Eocene/Oligocene boundary. Here, a major faunal change associated with a ${ }^{13} \mathrm{C}$ enrichment occurred in the early late Eocene; subsequent isotopic and faunal changes occurred in the late Eocene, culminating in a sharp increase in $\delta^{18} \mathrm{O}$ and $\delta^{13} \mathrm{C}$ near the Eocene/Oligocene boundary.

\section{PREVIOUS WORK}

Schnitker (1979) described Paleocene to Oligocene benthic foraminiferal assemblages recovered from Sites 400 $(4399 \mathrm{~m})$ and $401(2495 \mathrm{~m})$ on the Armorican Margin in the Bay of Biscay (Fig. 1). He suggested that a "peak in faunal turnover" occurred at the Eocene/Oligocene boundary, agreeing with Kennett and Shackleton (1976), who suggested that a crisis in deep-sea benthic foraminifers occurred at this time. Benson (1975) and Ducasse and Peypouquet (1979) noted that a major change in deep-sea ostracodes occurred between the middle Eocene and the early Oligocene, and suggested that this

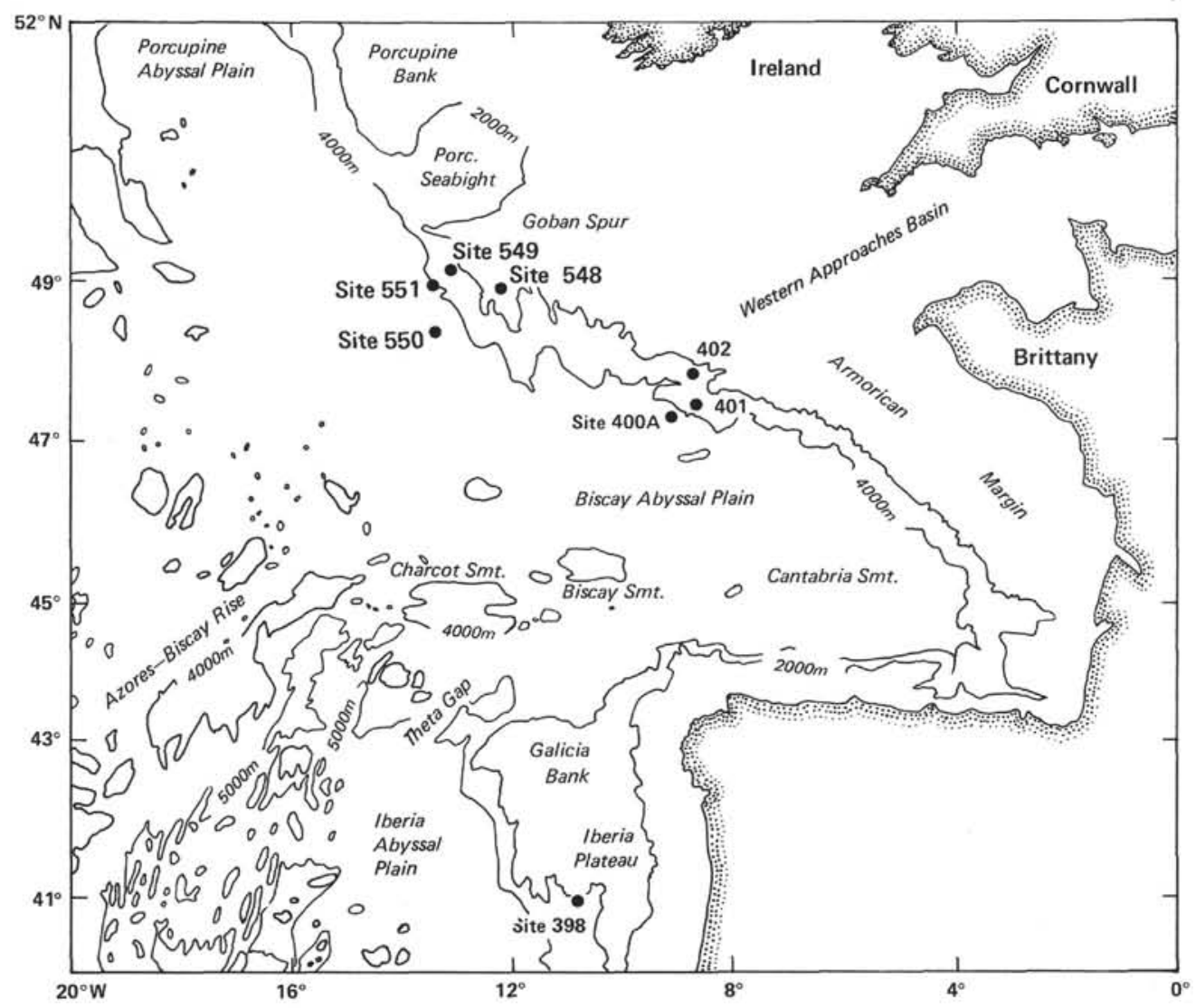

Figure 1. Site location map, Bay of Biscay (modified after Miller, 1983). 
change also occurred near the Eocene/Oligocene boundary. Subsequent workers disputed these conclusions. The upper Eocene section is missing at Site 400, and the Oligocene is missing at Site 401 (Montadert, Roberts, et al., 1979; Krasheninnikov, 1979; Müller, 1979); Schnitker's conclusions are therefore based upon a comparison of different time intervals from different depositional depths, and do not clearly document the timing of the taxonomic changes (Miller, 1983). Corliss (1979a; 1981), Tjalsma (1982), and Tjalsma and Lohmann (1983) hypothesized that no catastrophic changes occurred in response to the late Eocene to early Oligocene oceanographic changes, but that benthic foraminifers gradually or sequentially changed from the middle Eocene to the early Oligocene. As a means of testing this model, Corliss (1981) evaluated Schnitker's (1979) Site 400 data and concluded that in the Bay of Biscay there were two periods with an increased number of first and last appearances of taxa (Zones P12 and P18/19). Hiatuses and drilling disturbance encountered at Site $\mathbf{4 0 0}$ make it likely, however, that these periods of first and last appearances are artifacts of sampling. A more complete, undisturbed section is needed to determine late Paleogene faunal changes in the Bay of Biscay.

A major faunal change occurred between the early middle Eocene and the earliest Oligocene at two deep abyssal (both $>3 \mathrm{~km}$ ) sites in the Bay of Biscay (Sites 119 and 400); this faunal change resulted from the extinction of an assemblage dominated by Cretaceous and early Paleogene relict species. Nuttallides truempyi, Clinapertina spp., and Abyssamina spp., which dominated the Eocene abyssal benthic assemblage, were replaced by increasingly abundant, bathymetrically wide-ranging and stratigraphically long-ranging taxa: Oridorsalis spp., Globocassidulina subglobosa, Gyroidinoides spp., and the Cibicidoides ungerianus plexus. Most of the extinctions occurred before the early Oligocene, although upper Eocene hiatuses encountered at Sites 119 and 400 prevented dating the timing of these extinctions (Miller, 1983).

Eocene to Oligocene deep-sea benthic foraminiferal changes are better defined in the South Atlantic and Caribbean because of the more complete record recovered there. Here, Tjalsma and Lohmann (1983) showed that a sequence of faunal changes occurred during the middle Eocene to Oligocene: (1) a change from an early and middle Eocene Nuttallides truempyi assemblage to a late Eocene assemblage characterized by Globocassidulina subglobosa, Gyroidinoides spp., Cibicidoides ungerianus, and Oridorsalis umbonatus; (2) the extinction of $N$. truempyi in the latest Eocene; and (3) the appearance of Nuttallides umbonifera in the late Eocene. In addition, Tjalsma (1982 and pers. comm., 1982) noted that (4) N. umbonifera, G. subglobosa, Gyroidinoides spp., C. ungerianus, and $O$. umbonatus dominated in the Oligocene; and (5) no major changes in deep-sea benthic foraminiferal assemblages occurred across the Eocene/Oligocene boundary. The most dramatic of the middle Eocene to early Oligocene changes was the replacement of the $N$. truempyi assemblage by the $G$. subglobosa-Gyroidinoides-C. ungerianus-O. umbonatus as- semblage. On the basis of the replacement of $N$. truempyi at Site 357 (Rio Grande Rise) near the early/middle Eocene boundary, Tjalsma and Lohmann (1983) suggested that this replacement was diachronous, occurring in the early middle Eocene at shallow sites and near the middle/late Eocene boundary in deeper sites.

Conflicting paleoceanographic interpretations have been deduced from late Paleogene benthic foraminiferal changes. Schnitker $(1979,1980 a, b)$ ascribed the Eocene/ Oligocene benthic foraminiferal changes in the Bay of Biscay to the initial formation of cold bottom water derived from the Southern Ocean. Miller and Tucholke (1983) noted that the influence of any southern bottom water on the deep Bay of Biscay probably was minimal because of its inhibition by topographic barriers: the Azores-Biscay Rise (Fig. 1), the Azores-Gibraltar Rise, and the Madeira-Tore Rise. On the basis of this and the abyssal circulation model presented by Miller and Tucholke (1983), Eocene to Oligocene faunal (Miller, 1983) and isotopic (Miller and Curry, 1982) changes in the Bay of Biscay were attributed to initial input of northern (viz. the Norwegian-Greenland Sea and/or Arctic Ocean) sources of cold bottom water.

During the Oligocene, Nuttallides umbonifera replaced the Eocene species $N$. truempyi as the predominant abyssal benthic foraminifer in the Bay of Biscay, reaching peak abundance in the middle Oligocene at Sites 119 and 400. In the modern oceans, the abundance of $N$. umbonifera is positively correlated with increased corrosiveness of bottom water (Bremer and Lohmann, 1982); at Site 119 the greatest abundances of Nuttallides spp. are associated with the lowest $\delta^{13} \mathrm{C}$ values in benthic foraminifers (Miller and Curry, 1982). Lower $\delta^{13} \mathrm{C}$ values are often associated with water masses which are, in turn, more corrosive to carbonate (Kroopnick et al., 1972; Kroopnick, 1974, 1980; Lohmann and Carlson, 1981). Thus, the early to middle Eocene and middle Oligocene of Site 119 were interpreted as reflecting older (low $\mathrm{O}_{2}$, high nutrients, high $\mathrm{CO}_{2}$, low $\mathrm{pH}$, hence more corrosive) bottom water (Miller and Curry, 1982; Miller, 1983).

Miller and Curry (1982) reported on oxygen and carbon isotopic compositions of benthic foraminifers from Sites 119 and 401 . They found that $\delta^{18} \mathrm{O}$ values increased $\sim 1.9 \%$ and $\delta^{13} \mathrm{C}$ values increased $\sim 0.8 \%$ between the early middle Eocene (Zones NP13-NP15) and the earliest Oligocene (Zone NP21) of Site 119. They combined isotopic records for Sites 119 and 401 and concluded that $\sim 1.4 \% 0$ of the $\delta^{18} \mathrm{O}$ increase occurred in the late Eocene to earliest Oligocene. On the basis of biostratigraphic zonations, they could not resolve firmly the exact timing of the enrichment, which may have occurred within an interval of less than 1 m.y. (within Zone NP21) or an interval as long as $4 \mathrm{~m}$.y. (between Zones P15 and NP21).

The isotopic results of Vergnaud Grazzini et al. (1978, 1979) for Site 400 (Bay of Biscay) and of Vergnaud Grazzini (1979) for Site 398 (off Portugal) (Fig. 1) contrast with those of Miller and Curry (1982) in both magnitude and timing. Miller and Curry (1982) suggested, however, that the low Eocene benthic foraminiferal $\delta^{18} \mathrm{O}$ values noted at Sites 400 and 398 (as much as $2 \% 0$ lower 
than at Sites 119 and 401) resulted from the diagenetic alteration of foraminiferal tests in these more deeply buried sites.

\section{METHODS}

Benthic foraminifers were examined from the Eocene through Oligocene sections recovered at Site 549 (25 samples), Site 548 (13 samples), and Site 550 (14 samples). The samples were washed through a $63-\mu \mathrm{m}$ sieve with hydrogen peroxide (3\%) and sodium carbonate or a sodium hexametaphosphate solution. Aliquots from the $>149-\mu \mathrm{m}$ sizefraction (the size-fraction used by Tjalsma and Lohmann, 1983, and Miller, 1983) were picked and mounted on a reference slide. Approximately 300 to 500 specimens were picked whenever possible (Tables 1 and 2).

The benthic foraminifers were identified using the taxonomy outlined by Tjalsma and Lohmann (1983) and Miller (1983). The census data are presented as percent of total benthic foraminifers counted (Tables 1 and 2). Using computer programs provided by Lohmann (1980 and pers. comm., 1982), we made principal-component analyses and compared census values for Sites 548 (1256 m present depth) and 549 (2533 m present depth) with previous results from Sites 119 (4447 m present depth) and 401 ( $2495 \mathrm{~m}$ present depth) (both Bay of Biscay) and with the species distribution (percent) data of Tjalsma and Lohmann (1983).

We computed $Q$-mode principal components for Site 549 and Site 548 samples with more than 100 specimens, and computed loadings of the Bay of Biscay/Goban Spur samples onto Tjalsma's and Lohmann's (1983) Eocene $Q$-mode principal components. Tjalsma and Lohmann (1983) presented census data for 48 Eocene taxa that were used in all these computations. Although they did not record some taxa that were abundant in this study (mainly Astrononion pusillum), their $\mathbf{4 8}$ taxa account for approximately $70 \%$ of the total benthic foraminifers counted for Sites 549 and 548 (except Sample 549A-7-6, $118-123 \mathrm{~cm}$; Tables 1 and 2). Tjalsma's and Lohmann's (1983) 48 taxa also accounted for $\sim 70 \%$ of the total fauna counted within their data set (table 6 in Tjalsma and Lohmann, 1982).

Isotopic analyses were performed on samples of the benthic foraminiferal taxon Cibicidoides. Samples for isotopic studies were ultrasonically cleaned in distilled water, lightly crushed in methyl alcohol, and heated at $370^{\circ} \mathrm{C}$ in a vacuum to remove organic matter. The $\mathrm{CaCO}_{3}$ was reacted with $\mathrm{H}_{3} \mathrm{PO}_{4}$ at $50^{\circ} \mathrm{C}$. Evolved gas was frozen in a liquid nitrogen cold finger as it was produced. $\mathrm{CO}_{2}$ and water were separated by a series of distillations, and the purified $\mathrm{CO}_{2}$ was analyzed in an on-line VG Micromass 602E mass spectrometer at Woods Hole Oceanographic Institution. Results are presented as per mil differences from PDB. Analytical precision, based upon replicate analyses of NBS-20, is $\sim \pm 0.1 \%$ for both $\delta^{18} \mathrm{O}$ and $\delta^{13} \mathrm{C}$. Duplication of three benthic foraminiferal samples yielded results which differed by $0.16,0.3$, and $0.04 \%$ for $\delta^{18} \mathrm{O}$ and $0.03,0.04$, and $0.11 \%_{0}$ for $\delta^{13} \mathrm{C}$.

\section{RESULTS AND DISCUSSION}

\section{Water Depth vs. Time}

Sites 548 and 549 were drilled on continental crust, and therefore cannot be "backtracked" in the standard manner (Berger and Winterer, 1974; Sclater et al., 1977). Site 550 was drilled on ocean crust, however, and empirical age-vs.-subsidence curves for ocean crust (Sclater et al., 1971; Parsons and Sclater, 1977) can be used to "backtrack" this site; its subsidence can be used to estimate the subsidence of Sites 548 and 549. Backtracking Site 550 (4432 m present depth) along an empirical agesubsidence curve for the North Atlantic (Tucholke and Vogt, 1979), assuming that the crust is upper Albian ( $\sim 100$ m.y. old) and correcting for isostatic loading of sediments, suggests Eocene through Oligocene water depths of $\sim 4000$ to $4300 \mathrm{~m}$ (Montadert et al., this vol.). These estimates agree with faunal estimates of depositional depth $>3 \mathrm{~km}$. The benthic foraminifers at Site
550 are similar to assemblages noted at Site 119 and Site 440 (Miller, 1983) and to deep abyssal sites of Tjalsma and Lohmann (1983).

Assuming that the elevation difference of basement between Sites 550 and 549 remained constant $(\sim 1929 \mathrm{~m}$; de Graciansky, Poag, et al., this vol.), seafloor at Site 549 ( $2538 \mathrm{~m}$ present depth) was at $\sim 2000$ to $2300 \mathrm{~m}$ in the Eocene through Oligocene (Montadert et al., this vol.). Similarly, assuming a constant elevation difference between the basement at Sites 548 and 550, Eocene through Oligocene water depths were $\sim 1100$ to $1400 \mathrm{~m}$ (Montadert et al., this vol.).

Faunal evidence as to depositional depths supports these estimates. Tjalsma and Lohmann (1983) and Tjalsma (pers. comm., 1982) compiled benthic foraminiferal census data for DSDP sites on ocean crust that had been backtracked. Benthic foraminifers at Site 549 are typical for intermediate-depth sites when compared with the Eocene data of Tjalsma and Lohmann (1983). The absence of Abyssamina spp. and Clinapertina spp., low abundance of Aragonia spp. and Cibicidoides grimsdalei, and greater abundance of C. tuxpamensis, Hanzawaia cushmani, and Osangularia spp. are typical for sites between 2000 and $2500 \mathrm{~m}$. Similarly, comparison with Oligocene data (Tjalsma, pers. comm., 1982) shows that the low abundance of Lenticulina spp., Bulimina alazanensis, Siphonina, Nuttallides umbonifera, and high abundance of Astrononion pusillum also are typical for these depositional depths.

The Site 548 assemblages compare well with those from Site 516 (Rio Grande Rise, South Atlantic). Owing to uplift of Site 516 in the Eocene, it also cannot be backtracked in the usual manner; however, crude subsidence estimates place it near $1 \mathrm{~km}$ depth in the late Paleogene (Tjalsma, pers. comm., 1982). These assemblages are characterized by the very high abundance of Lenticulina spp. and B. alazanensis, high abundance of Planulina spp. and Siphonina spp., and lower abundance of pleurostomellids.

\section{Biostratigraphy, Site 549}

Two holes were cored at Site 549. Hole 549A was cored using a hydraulic piston from Cores 549A-1 through 549A-42 (Pleistocene to upper Eocene). Hole 549 (middle Eocene and older) was cored with a rotary drill. The samples we obtained for quantitative benthic foraminiferal studies were also examined qualitatively for planktonic foraminiferal content; in addition, nannofossil zonations for the samples were provided by M.-P. Aubry (pers. comm., 1982) (Table 3) to confirm the ages of the intervals that we sampled. The zonations presented here (and those for Sites 548 and 550) agree well with the zonations presented in the site chapters and elsewhere (Müller, this vol.; Snyder and Waters, this vol.); although some discrepancies occur between planktonic foraminiferal zonations in the middle Oligocene, the major stage and epoch boundaries coincide.

The placement of the Eocene/Oligocene boundary at Site 549 warrants further discussion. The boundary was placed at the level of the extinction of Globorotalia cerroazulensis cunialensis, G. cerroazulensis cocoaensis, 
Table 1. Benthic foraminiferal census data, Site 549.

\begin{tabular}{lcccccccccccccccccccccccccc}
\hline Sample number $^{\mathrm{a}}$ & 1 & 2 & 3 & 4 & 5 & 6 & 7 & 8 & 9 & 10 & 11 & 12 & 13 & 14 & 15 & 16 & 17 & 18 & 19 & 20 & 21 & 22 & 23 & 24 & 25 \\
& 25.5 & 26.5 & 27.4 & 28.4 & 29.5 & 35.5 & 36.0 & 36.4 & 36.7 & 36.7 & 36.8 & 36.9 & 37.0 & 37.1 & 37.5 & 37.8 & 38.3 & 38.7 & 38.5 & 40.0 & 42.0 & 44.0 & 45.9 & 47.5 & 49.5
\end{tabular}

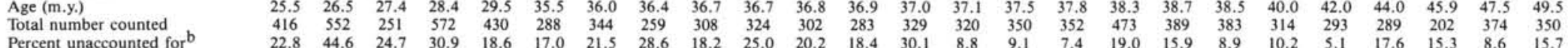

Species included in census of Tjalsma and Lohmann (1982)

Simple agglutinants

Spiroplectammina spp. Gaudryina pyramidata

Gaudryina cf. pyramidata

Karreriella subglabra

Stilostomella aculeate

S. gracillima

S. subspinosa
Aragonia spp.

Bulimina alazanensis

B. tuxpamensis

Buliminella gra

Bulimina jarvisi

B. callahani

B. semicostata

B. glomarchallengeri

B. trinitatensis/impendens

Turrilina spp.

Uvigerina rippinensis

Quadrimorphina sp.

Clinapertina spp.

Nonion havanense

Pullenia eocenica

Pullenia quinqueloba

Gyroidinoides spp.

Anomalina spissiformis

Gavelinells capitata/semicribrata

Gavelinella micra

Oridorsalis umbonatus

Osangularia spp.

Alabamina dissonata

Globocassidulina subglobosa

Cibicidoides grimsdalei

C. haitiensis

Cibicicoides ungerianus

C. tuxpamensis

C. cf. pseudoperlucidus

C. subspiratus

Cibicidoides laurisae

Astrononion pusillum

Cibicidoides sp. 1

Nuttallides umbonifera

Epistominella exigua

Cassidulina havanensis

Nonionella spp.

b Percent of total number counted not accounted for by the first 48 taxa in the table (i.e., the 48 species used by Tjalsma and Lohmann, 1982)

Species not included in census of Tjalsma and Lohmann

$\begin{array}{lllllllllllllllllllllllll}0.0 & 0.0 & 0.0 & 0.0 & 0.0 & 0.0 & 0.0 & 0.0 & 0.0 & 1.2 & 0.0 & 0.0 & 0.0 & 0.0 & 0.0 & 0.0 & 0.0 & 0.0 & 0.0 & 0.0 & 0.0 & 0.0 & 0.0 & 0.0 & 0.0\end{array}$

$\begin{array}{lllllllllllllllllllllllll}0.0 & 0.0 & 0.0 & 0.0 & 0.0 & 0.0 & 0.0 & 0.0 & 0.0 & 0.0 & 0.0 & 0.0 & 0.0 & 0.0 & 0.5 & 0.0 & 0.0 & 0.5 & 0.0 & 0.0 & 0.3 & 0.3 & 0.0 & 0.0 & 0.0\end{array}$

$\begin{array}{lllllllllllllllllllllllll}0.0 & 0.0 & 0.0 & 0.0 & 0.0 & 0.0 & 0.0 & 0.0 & 0.0 & 0.0 & 0.0 & 0.0 & 0.0 & 1.3 & 0.0 & 0.0 & 0.0 & 0.0 & 0.0 & 0.0 & 0.0 & 0.0 & 0.0 & 0.0 & 0.3 \\ 0.0 & 0.0 & 0.0 & 0.0 & 0.0 & 0.0 & 0.0 & 0.0 & 0.0 & 0.0 & 0.0 & 0.0 & 0.0 & 0.3 & 0.3 & 0.0 & 0.0 & 0.0 & 0.5 & 0.0 & 0.0 & 0.0 & 0.0 & 0.0 & 0.0\end{array}$

$\begin{array}{lllllllllllllllllllllllll}0.5 & 0.5 & 0.0 & 1.2 & 0.2 & 0.7 & 0.0 & 0.0 & 0.0 & 0.0 & 0.0 & 0.0 & 0.0 & 0.3 & 0.3 & 0.0 & 0.0 & 0.0 & 0.0 & 0.0 & 0.0 & 0.0 & 0.0 & 0.0 & 0.0 \\ 0.5 & 0.0 & 0.0 & 0.5 & 0.2 & 0.0 & 0.3 & 0.0 & 0.6 & 0.3 & 0.3 & 0.0 & 1.8 & 0.0 & 1.1 & 4.0 & 4.0 & 0.5 & 0.5 & 0.3 & 1.4 & 0.7 & 1.0 & 1.3 & 1.1\end{array}$

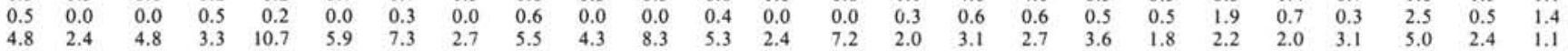

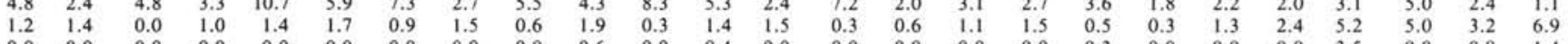

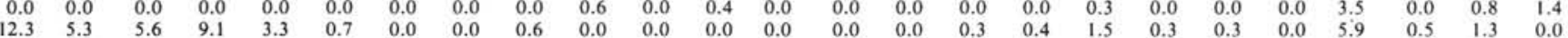

$\begin{array}{lllllllllllllllllllllllll}4.3 & 0.0 & 6.4 & 2.4 & 0.9 & 4.9 & 0.9 & 2.7 & 0.6 & 1.2 & 3.0 & 1.8 & 4.6 & 0.6 & 0.6 & 4.0 & 2.3 & 4.1 & 3.1 & 1.9 & 1.7 & 0.0 & 2.0 & 0.0 & 0.0\end{array}$

$\begin{array}{lllllllllllllllllllllllll}0.0 & 0.0 & 0.0 & 0.0 & 0.0 & 0.0 & 0.0 & 0.0 & 0.0 & 0.0 & 0.0 & 0.0 & 0.0 & 0.0 & 0.0 & 0.0 & 0.0 & 0.0 & 0.0 & 0.0 & 0.0 & 0.0 & 0.0 & 0.8 & 0.0 \\ 0.0 & 0.0 & 0.0 & 0.0 & 0.0 & 0.3 & 0.0 & 0.0 & 0.0 & 0.6 & 0.3 & 0.7 & 0.3 & 0.6 & 0.0 & 0.0 & 0.0 & 0.0 & 0.0 & 2.5 & 0.0 & 0.0 & 0.5 & 0.0 & 0.0\end{array}$

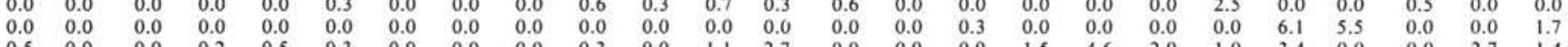

$\begin{array}{lllllllllllllllllllllllll}0.5 & 0.0 & 0.0 & 0.2 & 0.5 & 0.3 & 0.0 & 0.0 & 0.0 & 0.3 & 0.0 & 1.1 & 2.7 & 0.0 & 0.9 & 0.9 & 1.5 & 4.6 & 2.9 & 1.0 & 3.4 & 0.0 & 0.0 & 2.7 & 1.4\end{array}$

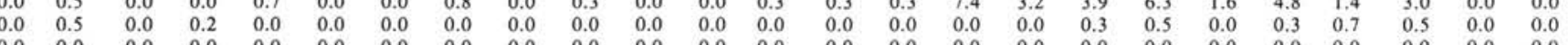

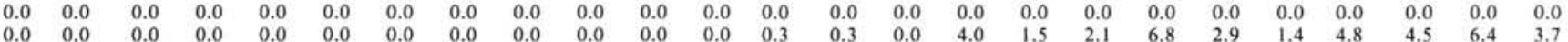

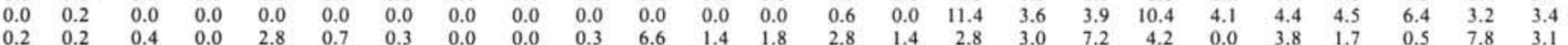

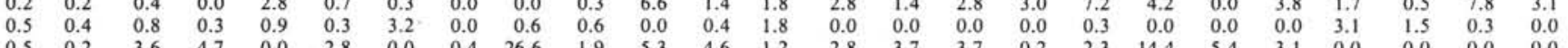

$\begin{array}{lllllllllllllllllllllllll}0.5 & 0.2 & 3.6 & 4.7 & 0.0 & 2.8 & 0.0 & 0.4 & 26.6 & 1.9 & 5.3 & 4.6 & 1.2 & 2.8 & 3.7 & 3.7 & 0.2 & 2.3 & 14.4 & 5.4 & 3.1 & 0.0 & 0.0 & 0.0 & 0.0\end{array}$

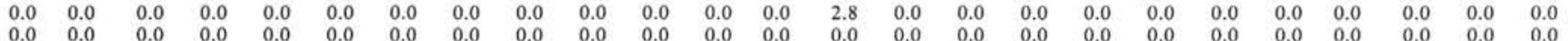

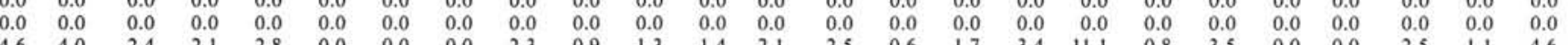

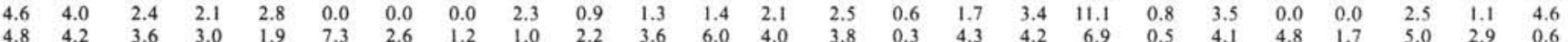

$\begin{array}{lllllllllllllllllllllllll}2.2 & 2.0 & 1.6 & 3.3 & 3.3 & 4.9 & 2.0 & 6.2 & 2.3 & 3.1 & 2.3 & 4.9 & 1.5 & 2.5 & 1.1 & 1.7 & 1.1 & 1.5 & 0.8 & 4.1 & 0.0 & 0.3 & 0.5 & 0.8 & 0.9\end{array}$

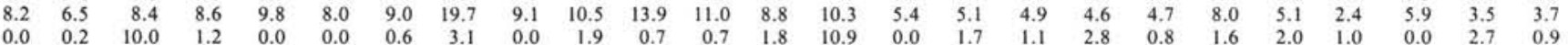
$\begin{array}{lllllllllllllllllllllllll}0.0 & 0.2 & 10.0 & 1.2 & 0.0 & 0.0 & 0.6 & 3.1 & 0.0 & 1.9 & 0.7 & 0.7 & 1.8 & 10.9 & 0.0 & 1.7 & 1.1 & 2.8 & 0.8 & 1.6 & 2.0 & 1.0 & 0.0 & 2.7 & 0.9 \\ 0.7 & 0.9 & 2.4 & 0.9 & 0.5 & 0.3 & 0.3 & 1.2 & 0.0 & 0.0 & 0.3 & 0.7 & 0.6 & 0.0 & 0.0 & 1.1 & 1.7 & 1.0 & 0.5 & 1.0 & 1.7 & 1.7 & 0.0 & 0.0 & 0.6\end{array}$ $\begin{array}{rrrrrrrrrrrrrrrrrrrrrrrrr}0.0 & 0.0 & 0.0 & 0.0 & 0.9 & 0.7 & 2.9 & 1.9 & 0.3 & 1.2 & 0.7 & 0.4 & 1.2 & 0.6 & 0.9 & 0.6 & 0.4 & 0.8 & 0.8 & 0.0 & 0.0 & 1.7 & 0.0 & 0.0 & 0.0 \\ 0.0 & 0.0 & 0.0 & 0.0 & 0.0 & 0.0 & 0.0 & 0.0 & 0.0 & 0.0 & 0.0 & 0.0 & 0.0 & 0.0 & 0.0 & 0.0 & 0.0 & 0.5 & 9.9 & 22.3 & 16.4 & 2.8 & 14.4 & 26.7 & 10.3\end{array}$

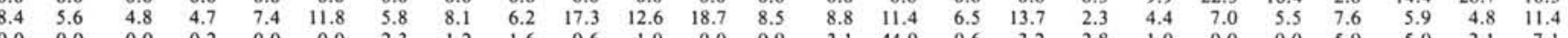

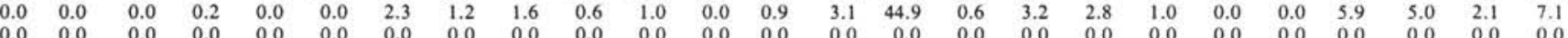

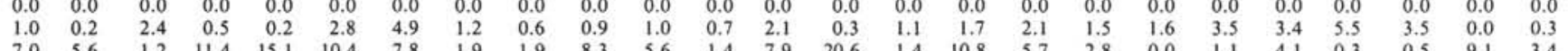

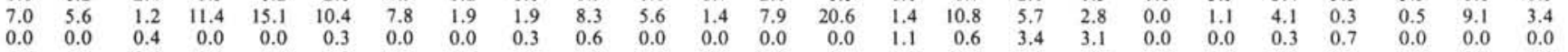

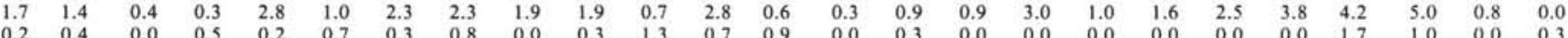

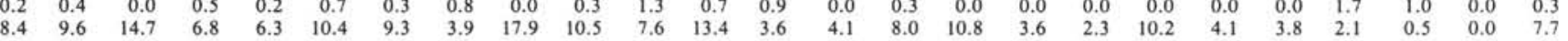
$\begin{array}{llllllllllllllllllllllllll}3.4 & 0.9 & 0.4 & 1.7 & 0.2 & 0.0 & 0.6 & 0.4 & 0.3 & 2.5 & 2.6 & 1.1 & 4.0 & 1.9 & 1.4 & 0.6 & 3.4 & 2.1 & 0.0 & 0.6 & 6.8 & 0.0 & 0.0 & 2.1 & 1.1\end{array}$

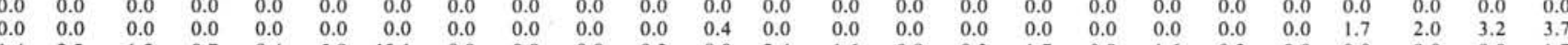

$\begin{array}{lllllllllllllllllllllllll}1.2 & 7.8 & 0.3 & 14.0 & 0.2 & 0.3 & 0.9 & 14.7 & 1.0 & 0.0 & 1.0 & 0.0 & 0.6 & 0.6 & 0.3 & 0.0 & 0.0 & 0.5 & \text { sp. } & \text { sp. } & 0.0 & 0.0 & 0.0 & 0.0 & 0.0\end{array}$ $\begin{array}{lllllllllllllllllllllllll}0.0 & 0.7 & 0.0 & 0.0 & 0.0 & 0.0 & 0.0 & 0.0 & 0.0 & 0.0 & 0.0 & 0.0 & 0.0 & 0.0 & 0.0 & 0.0 & 0.0 & 0.0 & 0.0 & 0.0 & 0.0 & 6.9 & 6.4 & 0.0 & 7.1 \\ 1.0 & 0.7 & 0.0 & 0.7 & 0.0 & 0.3 & 0.0 & 0.0 & 0.0 & 0.0 & 0.7 & 0.0 & 0.0 & 0.0 & 0.0 & 0.0 & 0.8 & \text { cf. } & 0.0 & 0.0 & 0.0 & 0.0 & 0.0 & 0.0 & 0.0\end{array}$

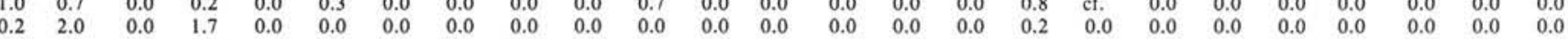

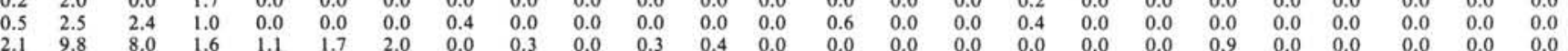

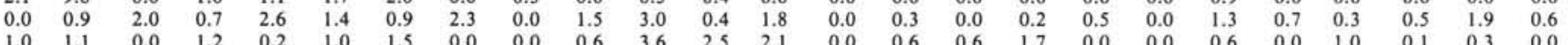


Table 2. Benthic foraminiferal census data, Site 548.

\begin{tabular}{|c|c|c|c|c|c|c|c|c|c|c|c|c|c|}
\hline Sample number ${ }^{\mathrm{a}}$ & 1 & 2 & 3 & 4 & 5 & 6 & 7 & 8 & 9 & 10 & 11 & 12 & 13 \\
\hline Age (m.y.) & 25.0 & 27.0 & 30.0 & 33.8 & 35.0 & 37.2 & 38.1 & 39.0 & 45.0 & 45.8 & 47.0 & 50.0 & 51.0 \\
\hline Total number counted & $? 83$ & 337 & 393 & 429 & 331 & 360 & 411 & 350 & 344 & 312 & 437 & 263 & 405 \\
\hline Percent unaccounted for ${ }^{b}$ & 20.8 & 23.4 & 26.7 & 31.2 & 20.5 & 29.4 & 22.6 & 17.1 & 12.2 & 13.8 & 2.7 & 24.3 & 16.5 \\
\hline \multicolumn{14}{|c|}{ Species included in census of Tjalsma and Lohmann (1982) } \\
\hline Simple agglutinates & 0.0 & 0.0 & 0.0 & 0.0 & 0.0 & 0.0 & 0.0 & 0.0 & 0.0 & 0.0 & 0.0 & 1.1 & 0.0 \\
\hline Spiroplectammina spp. & 0.3 & 0.3 & 1.0 & 0.0 & 0.0 & 0.0 & 0.0 & 0.0 & 0.3 & 1.3 & 1.1 & 0.0 & 0.2 \\
\hline Gaudryina cf. laevigata & 0.0 & 0.0 & 0.0 & 0.0 & 0.0 & 0.0 & 0.0 & 0.0 & 9.3 & 0.0 & 4.6 & 0.0 & 0.2 \\
\hline Gaudryina pyramidata & 0.0 & 0.0 & 0.0 & 0.0 & 0.0 & 0.0 & 0.0 & 0.0 & 0.0 & 0.0 & 1.4 & 1.1 & 0.0 \\
\hline Gaudryina cf. pyramidata & 0.0 & 0.0 & 0.0 & 0.0 & 0.0 & 0.0 & 0.0 & 0.0 & 0.0 & 0.0 & 1.6 & 0.0 & 0.0 \\
\hline Vulvalina spp. & 1.9 & 1.2 & 3.3 & 2.3 & 4.5 & 1.9 & 3.4 & 0.9 & 0.9 & 3.5 & 3.0 & 0.4 & 2.5 \\
\hline Karreriella subglabra & 0.7 & 0.9 & 0.0 & 0.0 & 0.9 & 0.0 & 0.0 & 0.6 & 0.3 & 0.6 & 1.6 & 0.4 & 0.0 \\
\hline Pleurostomella spp. & 0.1 & 0.6 & 1.0 & 1.4 & 2.4 & 0.0 & 0.2 & 0.9 & 2.0 & 2.6 & 0.0 & 0.4 & 2.2 \\
\hline Lemticulina spp. & 4.8 & 3.3 & 3.6 & 3.7 & 6.3 & 5.8 & 7.8 & 4.3 & 11.3 & 8.0 & 11.0 & 23.6 & 11.1 \\
\hline Stilostomella aculeata & 0.7 & 0.3 & 2.0 & 0.7 & 0.3 & 1.7 & 0.0 & 0.0 & 0.0 & 0.0 & 0.0 & 0.0 & 0.2 \\
\hline S. gracillima & 3.5 & 3.3 & 3.1 & 1.4 & 2.4 & 2.2 & 0.5 & 3.1 & 0.0 & 0.3 & 3.9 & 2.3 & 4.7 \\
\hline S. subspinosa & 0.6 & 0.6 & 0.0 & 0.5 & 0.3 & 0.8 & 1.2 & & 2.6 & 8.3 & 0.9 & 0.0 & 0.0 \\
\hline Aragonia spp. & 0.0 & 0.0 & 0.0 & 0.0 & 0.6 & 0.8 & 0.0 & 0.3 & 0.0 & 0.6 & 0.5 & 0.0 & 0.0 \\
\hline Bulimina alazanensis & 5.0 & 1.5 & 12.5 & 4.4 & 11.5 & 9.7 & 0.2 & 0.3 & 0.3 & 0.0 & 0.2 & 0.4 & 0.0 \\
\hline B. tuxpamensis & 0.0 & 0.0 & 0.0 & 0.0 & 0.0 & 0.0 & 1.0 & 0.0 & 4.4 & 6.1 & 0.7 & 0.4 & 0.0 \\
\hline Buliminella grata & 0.0 & 0.0 & 0.0 & 0.0 & 0.0 & 0.0 & 0.0 & 0.0 & 0.0 & 5.8 & 0.9 & 0.4 & 0.0 \\
\hline Bulimina jarvisi & 0.0 & 0.0 & 0.0 & 0.5 & 0.0 & 0.8 & 0.0 & 0.0 & 0.0 & 0.0 & 0.0 & 0.0 & 0.0 \\
\hline B. macilenta & 2.5 & 0.6 & 0.5 & 0.9 & 0.3 & 0.0 & 0.2 & 0.0 & 0.6 & 0.3 & 1.1 & 0.4 & 0.0 \\
\hline B. callahani & 0.0 & 0.0 & 0.0 & 0.0 & 0.0 & 0.0 & 0.0 & 0.0 & 0.0 & 0.0 & 0.0 & 0.0 & 0.0 \\
\hline B. semicostata & 0.0 & 0.0 & 0.0 & 0.0 & 3.6 & 5.0 & 0.0 & & 0.0 & 0.0 & 0.0 & 0.0 & 0.0 \\
\hline B. $g l$ & 0.0 & 0.0 & 0.0 & 0.0 & 0.0 & 0.0 & 0.0 & 0.0 & 0.0 & 0.3 & 0.2 & 16.3 & 6.4 \\
\hline B. trinitatensis/impendens & 4.8 & 4.7 & 5.3 & 4.7 & 0.0 & 2.8 & 3.9 & 11.7 & 2.0 & 5.1 & 4.8 & 1.5 & 2.0 \\
\hline Turrilin & 0.0 & 0.9 & 0.0 & 0.0 & & 0.8 & & & & & & & 6.2 \\
\hline Uvigerina rippinensis & 0.7 & 0.0 & 0.0 & 1.2 & 0.9 & 1.7 & 1.2 & 3.4 & 0.0 & 0.3 & 0.2 & 0.0 & 0.0 \\
\hline rphina s! & 0.0 & 0.0 & 0.0 & 0.0 & 0.0 & 0.0 & 0.0 & 0.0 & 0.0 & 0.0 & 0.0 & .0 & 0.0 \\
\hline & & 0.0 & 0. & 0.0 & & & & & & & & & 0.0 \\
\hline Clinaper & 0.0 & 0.0 & 0.0 & 0.0 & 0.0 & 0.0 & 0.0 & 0. & 0.0 & 0.0 & 0.0 & 0.0 & 0.0 \\
\hline Nanion havanen & 0.4 & 2.4 & 1.5 & 4.0 & 1.2. & 0.6 & 1.0 & I. & 0. & 2.9 & 2.7 & .4 & 5.2 \\
\hline & 4.1 & 4.5 & 5.1 & 1.2 & & 7. & 11.2 & & & & & & 0.0 \\
\hline Pullen: & 1.2 & 0.9 & 0.3 & 0.2 & 1.5 & 1.7 & 0.7 & 0.6 & 3.2 & 2.6 & 1.4 & 1.5 & 2.0 \\
\hline Gyroid & 9.1 & 9.8 & 5.1 & 6.1 & 6.6 & 5.6 & & 5. & 2.9 & 1.0 & 1.4 & 8 & 1.7 \\
\hline & 1.2 & 1.2 & 0. & 0.7 & 2. & 0. & & 1. & & & 4. & 2 & 4.7 \\
\hline Gavel: & 1.2 & 2.7 & 0.5 & 2.3 & 0.3 & 0.3 & 1.5 & 2. & 3.5 & 3.5 & 3.4 & 0.8 & 0.7 \\
\hline Gaveh & 0.0 & 0.6 & 0. & & & & & 1. & & 0. & 2.7 & 0.0 & 1.7 \\
\hline & 0.0 & 0. & 0. & 0. & & & & 0. & 10.2 & 5. & 12.8 & 10.3 & 18.0 \\
\hline & 5.1 & 9.8 & 2. & 3. & 2. & 6. & 4.4 & & 9.0 & 4.8 & 10.3 & 1.1 & 2.7 \\
\hline & 0.0 & 0.6 & 0. & & & 0. & & & & 0.0 & 0. & 1 & 0.7 \\
\hline & 0.0 & 0.0 & 0. & 0. & 0.0 & 0.3 & & 0. & 0.0 & & 0.0 & 0.0 & 0.0 \\
\hline Hanz & 0.0 & 0.0 & 0. & 0. & 0. & 0.0 & 0.2 & 2. & 0. & 1.5 & 6.9 & 0.0 & 0.0 \\
\hline & & 5.6 & 14.8 & & & 4.2 & 10.2 & & & 0. & 0.0 & 0.8 & 0.0 \\
\hline Cibicidoindes grimsdalei & 0.0 & 0.0 & 0.0 & 0.0 & 0.0 & 0.3 & 0.7 & 0.0 & 0.3 & 0. & 1.6 & 0.0 & 0.0 \\
\hline C. haitiensis & 2.3 & 1.8 & 1.5 & 2. & 3.6 & 1.9 & 1.0 & 1.7 & 4.1 & 1. & 0.0 & 0.0 & 3.2 \\
\hline & 0.0 & 0.0 & 0.0 & 0.2 & 0.0 & 0.3 & 0.5 & 0.0 & & 0.3 & 1.4 & 0.8 & 0.0 \\
\hline & 20.8 & 11.0 & 1.8 & 11.0 & 2.7 & 3.6 & 11.2 & 18,0 & 12.5 & 4. & 9.2 & 1.5 & 3,0 \\
\hline & 0.6 & 2.4 & 6.1 & 6. & 7.3 & 2.2 & 5.1 & 1.1 & 0.0 & & & & 0.0 \\
\hline C. $\mathrm{c}$ & & 0.0 & 0.0 & 0.0 & 0.0 & 0.0 & 0.0 & 0.0 & 0.0 & 0.0 & 0.0 & 0.0 & 0.0 \\
\hline C. subspiratus & 0.0 & 0.0 & 0.0 & 0.0 & 0.0 & 0.6 & 0.2 & 0.0 & 0.0 & 0.0 & 0.0 & 0.0 & 0.2 \\
\hline C. laurisae & 1.3 & 5.3 & 1.5 & 2.8 & 4.5 & 1.7 & 1.9 & 7.1 & 0.9 & 1.6 & 0.2 & 0.0 & 3.7 \\
\hline
\end{tabular}

Hantkenina alabamensis, and Cribrohantkenina (Plate 6). This occurs within the $22-\mathrm{m}$ interval assigned to Zone NP21 (Müller, this vol.; Table 3), which is defined by the presence of Ericsonia formosa, Discoaster tani nodifer, Isthmolithus recurvus, and Chiasmolithus oamaruensis after the extinction of $D$. saipanensis and $D$. barbadiensis (Müller, this vol.; M.-P. Aubry, pers. comm., 1982). This agrees with the relationships noted by Van Couvering et al. (1981), who pointed out that the extinction of planktonic foraminifers used to identify the top of the Eocene occurred before the extinction of the taxa used to define the top of Zone NP21. Thus, Zone NP21 straddles the Eocene/Oligocene boundary (see also Hardenbol and Berggren, 1978). Average sediment accumulation rate for the upper Eocene to lower Oligocene section was $\sim 20 \mathrm{~m} / \mathrm{m}$.y.; there is no evidence for a hiatus at the Eocene/Oligocene boundary, although core recovery was incomplete (Fig. 2). Although the uppermost lower Eocene through lower Oligocene section is probably continuous, a hiatus ( $\sim 6 \mathrm{~m}$.y.) or condensed interval probably occurs in the middle Oligocene of Hole 549A (between Samples 549A-11-6, 143-148 cm and 549A-10-6, 143-148 cm) (Fig. 2). This is suggested by the very low $(<4 \mathrm{~m} / \mathrm{m} . \mathrm{y}$.) middle Oligocene sediment accumulation rates, although every nannofossil zone and possibly every planktonic foraminiferal zone may be present (Müller, this vol.; Snyder and Waters, this vol.) and there is little physical evidence for an unconformity (site chapter). Still, the low middle Oligocene sediment accumulation rates are well established. That Sections 549A17-1 through 549A-11-6 belong to the lower Oligocene (upper Zone NP21 to Zone NP22) is well documented (Table 3). The overlying sample (from Section 549A-10-6) is assigned to Zone NP23 (M.-P. Aubry, pers. comm., 1982; Table 3); unfortunately, the planktonic foraminiferal zonal assignment is equivocal (Zone P21A or possibly Zone P20, Table 3; Zone P19/20, Snyder and Waters, this vol.). Sample 549A-9-6, 70-75 cm is upper Oligocene (Zone P21A; Zone NP24/NP25, M.-P. Aubry, pers. comm., 1982). Zone NP23 ( $\sim 5.5$ m.y. in duration; Hardenbol and Berggren, 1978) is therefore constrained to an interval less than $20 \mathrm{~m}$ thick (average accumulation rate $<4 \mathrm{~m} / \mathrm{m}$.y.), suggesting that a disconformity or at least a condensed interval may exist. The hiatus, if present, would correlate with a similar gap at Site 548.

The middle Oligocene hiatus delineated in Figure 2 may be revised in light of future biostratigraphic studies. Berggren (pers. comm., 1982) notes that the last appearance of Pseudohastigerina occurred not at the top 
Table 3. Zonal age assignments, Site 549.

\begin{tabular}{|c|c|c|c|c|}
\hline $\begin{array}{l}\text { Sample } \\
\text { no. }\end{array}$ & $\begin{array}{l}\text { Core-Section, } \\
\text { interval in } \mathrm{cm}\end{array}$ & NP zone $e^{a}$ & Foraminiferal zone $e^{b, c}$ & $\begin{array}{l}\text { Estimated age } \\
(\text { m.y.) }\end{array}$ \\
\hline \multicolumn{5}{|c|}{ Hole 549A } \\
\hline 1 & $6-6,100-105$ & NP24/NP25 & $\begin{array}{l}\text { G. ciperoensis (refs. } 1-3) \\
(=\mathrm{P} 22 / \mathrm{N} 4 \text {, refs. } 4-6 \text { ) }\end{array}$ & $\underline{25.5}$ \\
\hline 2 & $7-6,118-123$ & NP24/NP25 & P21B (refs. 4-6) & 26.5 \\
\hline 3 & $8-6,60-65$ & NP24/NP25 & P21B (refs, 4-6) & 27.4 \\
\hline 4 & $9-6,70-75$ & NP24/NP25 & P21A (refs, 4-6) & 28.4 \\
\hline 5 & $10-6,143-148$ & NP23 & P21A (refs. 4-6) (possibly P20) & 29.5 \\
\hline \multicolumn{5}{|c|}{ Hiatus } \\
\hline 6 & $11-6,143-148$ & NP22 & C. chipolensis/P. micra (refs. 1-3) & 35.25 \\
\hline 7 & $13-1,143-148$ & NP22 & C. chipolensis/P micra (refs. 1-3) & 35.6 \\
\hline 8 & $14-1,116-121$ & NP21 & C. chipolensis/P. micra (refs. 1-3) & 36.0 \\
\hline 9 & $15-1,116-121$ & NP21 & C. chipolensis/P. micra (refs. 1-3) & 36.4 \\
\hline 10 & $16-1,138-141$ & NP21 & C. chipolensis/P. micra (refs. 1-3) & 36.7 \\
\hline 11 & $16-2,24-27$ & NP21 & C. chipolensis/P. micra (refs. 1-3) & 36.7 \\
\hline 12 & $17-1,24-27$ & NP21 & C, chipolensis/P. micra (refs. 1-3) & 36.9 \\
\hline \multicolumn{5}{|c|}{ Eocene/Oligocene boundary } \\
\hline \multicolumn{5}{|c|}{ Hole 549A } \\
\hline 13 & $17-2,43-45$ & NP21 & G. cerroazulensis cunialensis (ref. 7) & 37.0 \\
\hline 14 & $18-1,103-106$ & NP21 & G. cerroazulensis cunialensis (ref. 7) & 37.1 \\
\hline 15 & $24-2,126-130$ & NP21 & G. cerroazulensis cunialensis (ref. 7) & 37.5 \\
\hline 16 & $28-1,143-146$ & NP19/NP20 & G. cerroazulensis cunialensis (ref. 7) & 37.8 \\
\hline 17 & $33-1,143-146$ & NP19/NP20 & $\begin{array}{l}\text { G. cerroazulensis cocoaensis (ref. } 7 \text { ) } \\
\text { ( - upper P15-P16, refs. 4-6) }\end{array}$ & 38.3 \\
\hline 18 & $35-1,26-28$ & $\mathrm{NP} 18^{\mathrm{d}}$ & $\begin{array}{l}\text { G. cerroazulensis cocoaensis (ref. 7) } \\
\text { ( } \text { upper P15-P16, refs. 4-6) }\end{array}$ & 38.7 \\
\hline 19 & $38-1,49-53$ & NP18 & $\begin{array}{l}\text { G. cerroazulensis cerroazulensis (ref. 7) } \\
(-\mathrm{P} 15, \text { refs. 4-6) }\end{array}$ & 39.5 \\
\hline 20 & $40-1,94-97$ & NP17/NP18 & $\begin{array}{l}\text { G. cerroazulensis cerroazulensis (ref. 7) } \\
(-\mathrm{P} 15 \text {, refs. 4-6) }\end{array}$ & $\underline{40.0}$ \\
\hline \multicolumn{5}{|c|}{ Hole 549} \\
\hline 21 & $2-5,126-129$ & - & P14 (refs. 4-6) (possibly earliest P15) & 42.0 \\
\hline 22 & $4-6,145-148$ & NP15/16 & $\mathrm{P} 12$ (P12-P13) (refs. 4-6) & 44.0 \\
\hline 23 & $6-6,148-150$ & NP15/16 & $\begin{array}{l}\text { upper P11-lower P12 (P11-P12) } \\
\text { (refs. 4-6) }\end{array}$ & 45.9 \\
\hline 24 & $8-4,145-147$ & NP15/16 & P11 (refs. 4-6) & $47.5^{\mathrm{e}}$ \\
\hline 25 & $10-5,57-61$ & NP13 & P9 (refs. 4-6) & 49.5 \\
\hline
\end{tabular}

a NP zonation data provided by M.-P. Aubry, pers. comm. (1982).

Planktonic foraminiferal zonation of references: (1) Bolli (1957a, b), (2) Bolli (1966), (3) Stainforth et al. (1975), (4) Blow (1969), (5) Hardenbol and Berggren (1978), (6) Blow (1979), (7) zonation of Toumarkine and Bolli (1970), (8) Cordey et al. (1970), (9) Toumarkine and Bolli (1975).

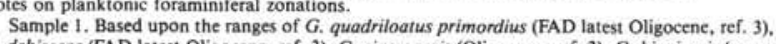
G. dehiscens (FAD latest Oligocene, ref. 3), G. ciperoensis (Oligocene, ref. 3), G. binaiensis (range G. ciperoensis Zone, ref. 3; P22-N5, ref. 6), G. opima nana, G. selli (LAD P22, ref. 6), G. angulof. ficinalis (LAD P22, ref. 6), C. chipolensis, G. suteri, D. galavisi (LAD P21, ref. 6), G. mendacis Samp, ref. 6), and C. unicavus.

Sample 2. Based upon G. opima opima (range P21, possibly P20, ref. 3), G. angulisuturalis (FAD base P21, ref. 3), G. opima nana, G. anguliofficinalis, G. ciperoensis, G. pseudobesa, C. un. icavus, C. dissimilis, $G$. praebulloides, and $D$. galavisi. Above the LAD of Chiloguembelina spp.
(LAD P21A). A pparently anomalous occurrence of $S$, cf, angiporoides, for although Blow (ref. notes its range into Zone P21, Stainforth et al. (ref. 3) note its extinction at the base of the G. am. pliapertura Zone.

Sample 3. As in Sample 2, with G. ouachitaensis (LAD P21, ref. 6) and G. tripartita. Sample 4. As in Sample 3, but with Chiloguembelina cubensis. The overlap of this species and

G. opima opima indicates Zone P21A (refs, 4-6)

Sample 5. G. opima opima (range P21, possibly P20, ref. 3), Chiloguembelina cubensis, G. permicra (LAD P21, possibly base P22, ref. 6), G. postcretacea (LAD in P21, ref, 3), G. euaperta, G. gortanii, G. munda, G. cf. pseudovenezuelana (LAD PI9/20, ref, 6), and $S$. ef, angiporoides (LAD lower $\mathrm{P} 20$, ref. 3). The absence of $G$. angulisuturalis suggests that this may be Zone P20, and therefore that $G$. opima opima, which is found in abundance, has its FAD in that zone. Sample 6. Based upon the occurrence of Pseudohastigerina barbadoensis (LAD top C. chipo. lensis/P. micra Zone, ref. 3), G. ampliapertura (LAD top P20, ref. 3), S. angiporoides, G. opima nana, $G$. increbescens (LAD P19/20, ref. 6; late Eocene to early Oligocene, ref. 3), G. euaperto (FAD P19/20, ref. 6), C. unicavus, and D. galavisi.

Sample 7. As in Sample 6, with G. pseudovenezuelana, G. increbescens, G. postcretacea, G. tripartita, and G. senilis.

Sample 8. G. tapuriensis (range P18-P19/20, ref. 6), G. opima nana, C. unicavus, D. galavisi, $G$. euaperta, and $G$. permicra. The occurrence of $G$. euaperta in this sample, together with nannofossils indicative of Zone NP21 after the extinction of characteristic Eocene planktonic foraminiers ( $=$ Zone P18), disagrees with the range given by Blow (FAD P19/20, ref. 6).

Interval from Sample 6 to Sample 12. These samples contain low-diversity, predominantly simple globigeriniform planktonic foraminifers which are not age-diagnostic. This interval is assigned to the $C$. chipolensis/P. micra Zone on the basis the presence of Preudohatigering after the extinction of the $G$. cerroazulensis group and Hantkenina spp.

Sample 13. Based upon the presence of $G$. cerroazulensis cunialensis (FAD base of $G$. cunalensis Zone, ref. 7: - upper P16-lower P17), G. cerroazulensis cocoaensis, G. cerroazulensis cocoaensis transitional to $G$. cerroazulensis cunialensis and $G$. cerroazulensis cerroazulensis, Cribrohanikenina, Hantkenina alabamensis, G. opima nana, G. ampliapertura, S. angiporoides, and $P$.
micr. Sample

ample 14. As in Sample 13.

Sample 15. As in Sample 13, with G. mexicana, G. tropicalis, and G. pastcretacea (FAD G. cerazulensis s.l. Zone, ref. 3)

Sample 16. Toumarkine and Bolli (ref. 9) noted that in the Possagno section, Italy, G. ampliapertura had its first appearance just above the FAD of $G$. cerroazulensis cunialensis. The absence of $G$. ampliapertura, together with the presence of the nominate $G$. cerroazulensis cunialensis in Sample 16, suggests that this sample may be assigned to the lower portion of the zone. Samples 17 and 18. These are assigned to the $G$. cerroazulensis cocoaensis Zone on the basis of the first appearance of the nominate taxa in Sample 18 (ref. 7; - upper G. seminnvolufa to lower $G$. Eocene $G$. cerroazulensis cerroazulensis Zone (ref. 7).

Sample 19. Based upon the presence of $G$. cerroazulensis cerroazulensis, G. cerroazulensis pomeroli, $G$. opima nana, $S$. angiporoides, and $G$. increbescens below the first occurrence of $G$. cerroazulensis cocoaensis.

Sample 20. As in Sample 19, with A. spinuloinflata (ranges into Zone P15, ref. 6).
Table 3. (Continued).

Sample 21. Based upon the presence of $G$. cerroazulensis pomeroli ( $=$ centralis of Blow, refs. 4 and 6) (FAD upper P12, ref. 7), M. spinulosa (P10-P14, ref. 3), T. rohri (LAD top P14, refs. 1-4; LAD base P15, ref. 6), G. opima nana, and S. angiporoides (both FAD PI5, ref. 3). This assemblage is a very similar to that noted in Section 548A-17-5, except for the absence of $G$. semiinvolu$t a$, which is used by Blow (ref. 6) to differentiate Zone P14 from Zone P15. The overlap of G. opima nana and $S$. angiporoides with $M$. spinulosa and $T$. rohri is not considered to be the result of reworking or contamination, and therefore contradicts the ranges for the former taxa given by Stainforth (ref. 6), but agrees with Blow's ranges.

Sample 22. Based upon the presence of $G$. frontosa (LAD P12, refs. 3 and 7), M. spinulosa coronata (P10-P13, ref. 6), G. cf. cerroazulensis possagnoensis (upper P11-lower P12, ref. 7), T. topilensis (P12-lower P14, ref. 6), M. spinulosa, A. densa, D. galavisi, S. linaperta, P. micra, P. ef. wilcoxensis, and $G$. index.

Sample 23. Based upon the presence of G. frontosa (P9-P12, ref. 3; LAD P11, refs. 3 and 6). G. index (FAD late P11, ref. 3), G, higginsi (P9-P11/early P12, ref. 6), $T$. rohri, A. bullbrooki $(=A$. densa), $S$. crociaperta, D. galavisi, and $G$. linaperto.

Sample 24. Based upon the presence of $G$. broedermanii broedermanii (P6b-P11, ref. 3; to

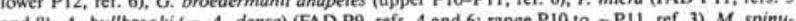
and 8), A. bullorooki ( $=$ A. densa) (FAD

Sample 25. Based upon the presence of G. caucasica (P8-P9, ref. 3), A. bullbrooki ( $=$ A. densa) (FAD P9, refs. 4 and 6; range P10- - PII, ref, 3), D. galavisi (FAD P9, refs. 4 and 6), G. renzi (P8-P14, ref. 3), G. frontose (Fily middle Eocene, ref. 8 ).

d Age discrepancies between planktonic foraminiferal and nannofossil age assignments.

e Age discrepancies between planktonic foraminiferal and nannofossil age assignments. Age discrepancies between zonal age assignment and estimated age in m.y. result from interpolaabove; Fig. 2).

of Zone P19/20 and near the Zone NP23/NP24 boundary, as he suggested previously (Berggren, 1971, 1972b; Hardenbol and Berggren, 1978), but at the NP22/NP23 boundary. Nevertheless, revisions in the Paleogene time scale and zonations (Berggren, pers. comm., 1982) apparently will not substantially alter the length of Zone NP23; therefore, it is probable that a disconformity exists between Samples 549A-9-6, 70-75 cm and 549A-11-6, $143-148 \mathrm{~cm}$.

The zonal schemes outlined in Tables 3 and 4 are dated using the time scale of Hardenbol and Berggren (1978). There is considerable debate as to the age of the Eocene/Oligocene boundary, with one school (Odin, 1978; Odin et al., 1978; Glass and Crosbie, 1982) suggesting an age of 32 m.y. and another school maintaining an age of $\sim 37$ m.y. (Berggren, 1972b; Hardenbol and Berggren, 1978; Berggren, pers. comm., 1982). We have used the latter. Revisions or differences in the time scale used could substantially alter the "absolute timing" of the benthic events dated here. Still, the events presented are correlated with planktonic zonations, and are therefore well established (both biostratigraphically and biochronologically) relative to the various stage/epoch boundaries. The chronostratigraphic relationships of these events should not change substantially.

\section{Benthic Foraminiferal Isotopic Record, Site 549}

Isotopic analyses were performed on monogeneric samples of the benthic foraminiferal taxon Cibicidoides (Plates 1 and 2). Interregional isotopic variations of this taxon in Holocene core tops reflect the distribution of temperature, $\delta^{18} \mathrm{O}$ of seawater, and $\delta^{13} \mathrm{C}$ of $\Sigma \mathrm{CO}_{2}$ of seawater in the modern oceans (Belanger et al., 1981; Graham et al., 1981). Cibicidoides species secrete their tests lower in $\delta^{18} \mathrm{O}$ than equilibrium values calculated from the Epstein et al. (1953) paleotemperature equation; this offset appears to be constant ( $\sim 0.65$ lower, Shackleton and Opdyke, 1973; Duplessy et al., 1980; Woodruff et al., 1980; Belanger et al., 1981; Graham et al., 1981). In sampling, we noted an increase in lithification in Hole 549, Cores 549-3 to 549-8. Benthic foraminiferal recovery and preservation were poor in these cores. We there- 


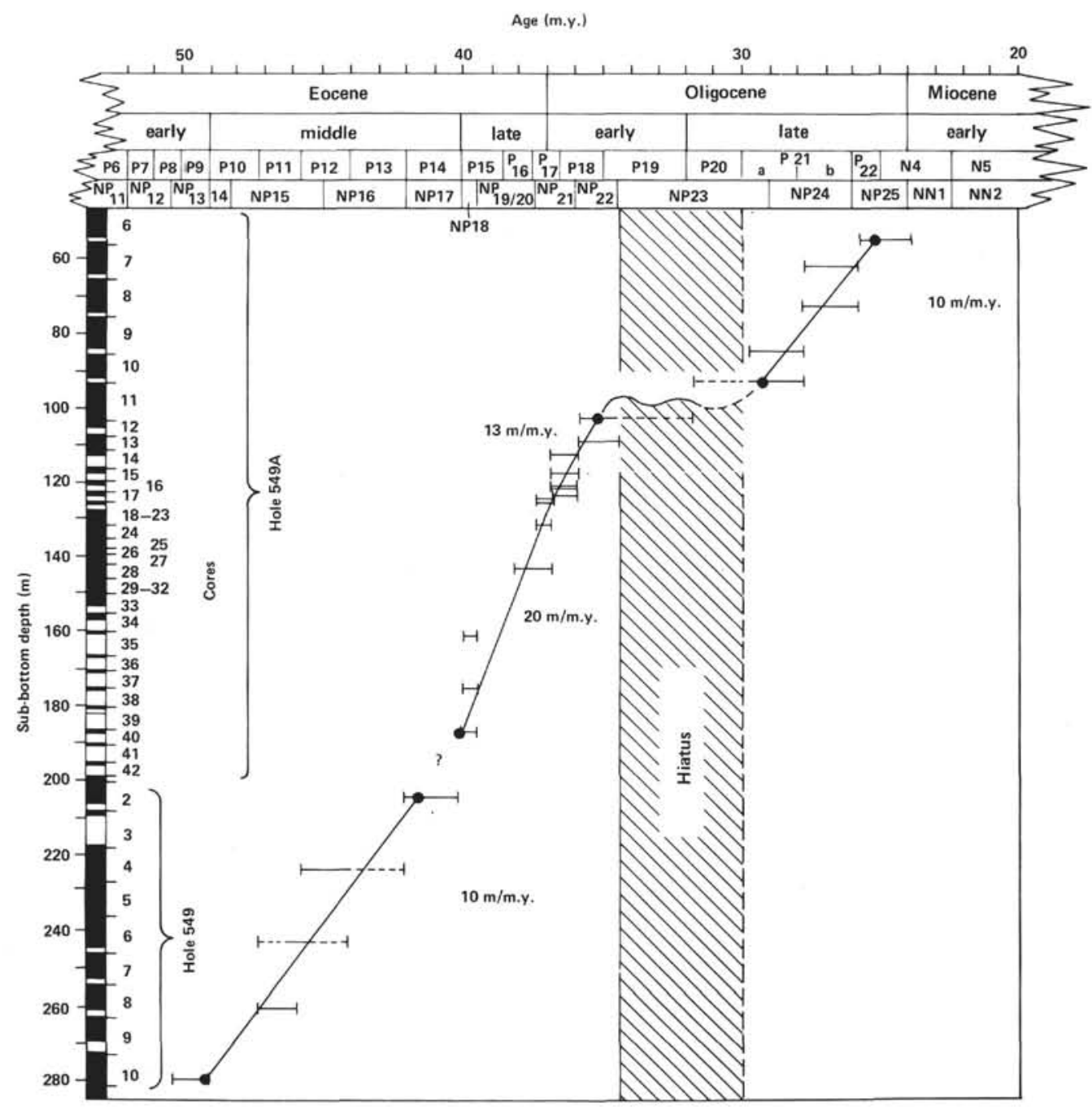

Figure 2. Zonal age assignments and estimated average sediment accumulation rates, Site 549. Error bars show the length of the biozone(s) to which the samples have been assigned (Table 3). Solid dots indicate ties for interpolating estimates of sediment accumulation rate and age.

fore suspected diagenetic alteration of the sediments recovered in Hole 549 (as was noted at Sites 400 and 398), even though the burial depths for these cores are only $\sim 220$ to $280 \mathrm{~m}$. Insufficient benthic foraminifers were available for analysis through most of this section. Oxygen isotopic values for Cores 549-8 and 549-10 are low $(\sim 0.0$ and $-1.0 \%$ PDB, respectively) (Fig. 3, Table 5) relative to other lower to lower middle Eocene values for Site 119 and to lower through middle Eocene values for Site 401 (both $\sim 0.5 \%$ PDB; Miller and Curry, 1982). These low values are similar to those noted from the diagenetically altered sections of Sites 400 and 398 (Vergnaud Grazzini et al., 1978, 1979; Vergnaud Grazzini, 1979). Miller and Curry (1982) noted that such differences within the Bay of Biscay are oceanographically unreasonable and too great to be explained by sample biases alone (selective dissolution, analyses of mixedvs.-monogeneric assemblages). We therefore interpret these values as resulting from diagenetic alteration.

Samples from Hole 549A (and Core 549-2) show less lithification and better preservation and recovery of ben- thic foraminifers, whereas oxygen and carbon isotopic values are similar (Figs. 3 and 4) to the apparently unaltered isotopic records at Sites 401 and 119 (Miller and Curry, 1982). Oxygen isotopic composition is relatively constant across the middle/upper Eocene boundary $(\sim 0.6 \%)$ (Fig. 3); values increased $\sim 0.3 \%$ in the late Eocene and $\sim 0.7 \%$ in the earliest Oligocene for a total late Eocene-to-earliest Oligocene increase of $\sim 1.0 \%$. Little $\delta^{18} \mathrm{O}$ change occurred in the Oligocene following the earliest Oligocene maximum. The value of $\delta^{13} \mathrm{C}$ increased $\sim 0.8 \%$ in the early late Eocene, decreased $\sim 0.4 \%$ in the latest Eocene, and increased $\sim 0.6 \%$ in the earliest Oligocene (Fig. 3). The magnitude of the late Eocene to earliest Oligocene ${ }^{18} \mathrm{O}$ enrichment is greater in the Site 119/401 composite than at Site $549(\sim 1.5$ and $\sim 1.0 \%$, respectively). This may reflect a greater temperature drop at the deep Site 119 relative to the shallower Site 549 (the Oligocene portion of the composite record is from Site 119). The carbon isotopic record shows greater detail for the late Eocene to earliest Oligocene at Site 549, but does not show the distinct middle 
Table 4. Zonal age assignments, Site 548 (Hole 548A).

\begin{tabular}{|c|c|c|c|c|}
\hline $\begin{array}{l}\text { Sample } \\
\text { no. }\end{array}$ & $\begin{array}{l}\text { Core-Section, } \\
\text { interval in } \mathrm{cm}\end{array}$ & NP zone ${ }^{a}$ & Foraminiferal zone ${ }^{b}$ & $\begin{array}{c}\text { Estimated age } \\
(\mathrm{m} . \mathrm{y} .)\end{array}$ \\
\hline 1 & $15-6,52-56$ & NP24/25 & G. ciperoensis (refs. 1-3) & 25.0 \\
\hline 2 & $16-1,99-102$ & NP24 & P21B (refs. 4-6) & 27.0 \\
\hline 3 & $16-3,66-69$ & $\left(\mathrm{NP}_{23}\right)^{\mathrm{C}}$ & ?P20 (refs. 4-6) & 29.0 \\
\hline \multicolumn{5}{|c|}{ Major hiatus ${ }^{d}$} \\
\hline 4 & $16-4,66-69$ & $\begin{array}{l}\text { NP22 } \\
\text { (possibly } \\
\text { NP23) }\end{array}$ & C. chipolensis/P. micra (refs. 1-3) & 35.0 \\
\hline 5 & $16-5,23-26$ & NP22 & C. chipolensis/P. micra (refs. 1-3) & 35.4 \\
\hline \multicolumn{5}{|c|}{ Possible minor hiatus } \\
\hline 6 & $17-1,99-102$ & NP21 & G. cerroazulensis s.1. (refs. 1-3) & 37.2 \\
\hline 7 & $17-3,102-105$ & NP19/20 & G. cerroazulensis s.l. (refs, 1-3) & 38.4 \\
\hline 8 & $17-5,121-124$ & NP18 & earliest P15 (ref. 6) & 39.8 \\
\hline \multicolumn{5}{|c|}{ Major hiatus } \\
\hline 9 & $18-3,98-101$ & NP15/16 & P12 (refs. 4-6) & 45.0 \\
\hline 10 & $19-5,88-91$ & NP15/16 & P11 (refs. 4-6) & 45.8 \\
\hline 11 & $21-4,55-58$ & $\mathrm{NP} 15 / 16$ & P10-11 (refs. 4-6) & 47.0 \\
\hline \multicolumn{5}{|c|}{ Major hiatus } \\
\hline 12 & $22-6,94-97$ & NP12 & P8-9 (refs. 4-6) & 50.0 \\
\hline 13 & $24-1,38-41$ & NP12 & P8 & 51.0 \\
\hline
\end{tabular}

a NP zonation data provided by M.-P. Aubry, pers. comm. (1982).

b Planktonic foraminiferal zonation references: (1) Bolli (1957a, b), (2) Bolli (1966), (3) Stain forth et al. (1975), (4) Blow (1969), (5) Hardenbol and Berggren (1978), (6) Blow (1979), (7) zonation of Toumarkine and Bolli (1970).

c Poag et al. (this vol.) and Müller (this vol.) report that Zone NP24 occurs just above the disconformity, whereas Zone NP23 occurs just below. The identification of Zone NP23 above the hiatus probably results from our sampling portions of reworked sediment; the identification of Zone NP22 in Sample 548A-16-4, 66-69 cm is consistent with the identification of Müller (this vol.).

d The very low sediment accumulation rates computed for the section above the hiatus (less than $\sim 1 \mathrm{~m} / \mathrm{m} . \mathrm{y}$.) suggests that it is discontinuous.

Oligocene $\delta^{13} \mathrm{C}$ minimum noted at Site 119 (Miller and Curry, 1982), probably owing to a hiatus (see the preceding).

The $\delta^{18} \mathrm{O}$ values we report for Site 549 are similar to values obtained in the Southern and Pacific oceans: Sites 277 (Campbell Plateau; 1214 m water depth; Kennett and Shackleton, 1976; Keigwin, 1980) and Site 298 (Philippine Sea; 2943 m water depth; Keigwin, 1980). Keigwin noted that ${ }^{18} \mathrm{O}$ enrichments of $\sim 1.0$ and $\sim 1.5 \%$ occurred at Sites 277 and 292, respectively, just above the level of the Eocene/Oligocene boundary (following the extinction of Eocene planktonic foraminifers; Keigwin, 1980). Comparison of Keigwin's $\delta^{18} \mathrm{O}$ records with the benthic foraminiferal $\delta^{18} \mathrm{O}$ record at Site 549 (Fig. 5) shows that the enrichments at all three locations may be considered synchronous. This conclusions assumes that the extinctions of the planktonic foraminifers used to defined the Eocene/Oligocene boundary in all three cases were synchronous (Site 549, this chapter; Site 277, Kennett, Houtz, et al., 1975; Site 277, Karig, Ingle et al., 1975). The magnitude of the ${ }^{18} \mathrm{O}$ enrichment is the same at both Site 549 and Site 277 . The magnitude of the enrichment at Site 292 is greater by $\sim 0.5 \%$, but is similar to that noted in the Site 119/401 composite (Fig. 4).

The ${ }^{18} \mathrm{O}$ enrichment in benthic foraminifers may represent a change in the isotopic composition of sea water or a drop in bottom-water temperature or both. Early studies suggested that the major buildup of continental ice in the Tertiary did not occur until the middle Miocene, and, therefore, that the enrichment noted near the Eocene/Oligocene boundary represents a major cooling (Shackleton and Kennett, 1975; Savin et al., 1975; Kennett and Shackleton, 1976; Savin, 1977). Matthews and Poore (1980) suggested, on the other hand, that the en- richment may represent the first major buildup of continental ice on Antarctica. Geological evidence of a major pre-Miocene ice cap on Antarctica is debatable, but it is possible that a major ice cap formed in the earliest Oligocene (see summary in Kerr, 1982).

The Matthews and Poore (1980) model requires that the enrichment in ${ }^{18} \mathrm{O}$ of both benthic and tropical planktonic foraminifers must have been globally synchronous, unless affected by local temperature and salinity perturbations. Presently, two exceptions to this synchronous enrichment apparently exist: at Site 292 the enrichment occurs mainly in benthic foraminifers (1.5 vs. only $0.3 \%$ enrichment in planktonic foraminifers) (Keigwin, 1980); and in the South Atlantic (Site 357), the isotopic enrichment took place between the middle and late Eocene (Boersma and Shackleton, 1977). The record recovered at Site 357 is incomplete, however, and Boersma and Shackleton (1977) reported only one value for the late Eocene to earliest Oligocene (P15-P18) at this site. Keigwin argued that the $\delta^{18} \mathrm{O}$ increase in benthic foraminifers represents mostly a temperature decrease because of the lack of covariance at tropical Site 292, although this could be attributed, in part, to a local surface-water warming or a decrease in salinity in the Philippine Sea. Assuming buildup of glacial ice from an ice-free Eocene world to a fully glaciated Oligocene world (with ice volume equal to present-day ice volume), Miller and Curry (1982) argued that the $\delta^{18} \mathrm{O}$ increase must represent at least a $2^{\circ} \mathrm{C}$ temperature drop.

The late Eocene to earliest Oligocene $\delta^{13} \mathrm{C}$ records at Sites 549 and 277 show remarkably similar patterns, although the values are offset, differing by $\sim 1.0 \%$, in part because of the different species analyzed (Cibicidoides spp., Site 549; Oridorsalis spp., Site 277, Keigwin, 1980) (Fig. 6). It might be hypothesized that the $\delta^{13} \mathrm{C}$ records are correlative, and that they are a function of global changes in carbon, reflecting changes in either sea level (hence increased terrestrial-carbon or shelf-carbon input; Shackleton, 1977; Broecker, 1982) or global circulation. We believe, however, that the offsets in time shown in the $\delta^{13} \mathrm{C}$ records (Fig. 6) are real. Assuming that the peaks in $\delta^{13} \mathrm{C}$ are correlative results in the diachronous placement of the $\delta^{18} \mathrm{O}$ changes and the diachronous extinction of the planktonic foraminifers used to identify the Eocene/Oligocene boundary. The lack of a similar $\delta^{13} \mathrm{C}$ record at Site 292 argues against global changes in the carbon budget. The coincidence of the $\delta^{18} \mathrm{O}$ increase and planktonic foraminiferal extinctions at all three sites argues that the $\delta^{18} \mathrm{O}$ increases correlate (again, assuming isochronous extinctions of planktonic foraminifers) and that the changes in $\delta^{13} \mathrm{C}$ at Sites 277 and 549 were, in fact, slightly diachronous.

\section{Benthic Foraminiferal Assemblages, Site 549}

The lower to middle Eocene assemblages are dominated by Nuttallides truempyi (Plate 3 ) and buliminids (Bulimina glomarchallengeri, B. trinitatensis/impendens, $B$. semicostata, with $B$. jarvisi [Plate 4] becoming important in the upper middle Eocene) (Figs. 7 and 8). Lenticulina spp., Cibicidoides sp. 1, and Osangularia spp. (Fig. 8) are also more abundant in the lower to mid- 


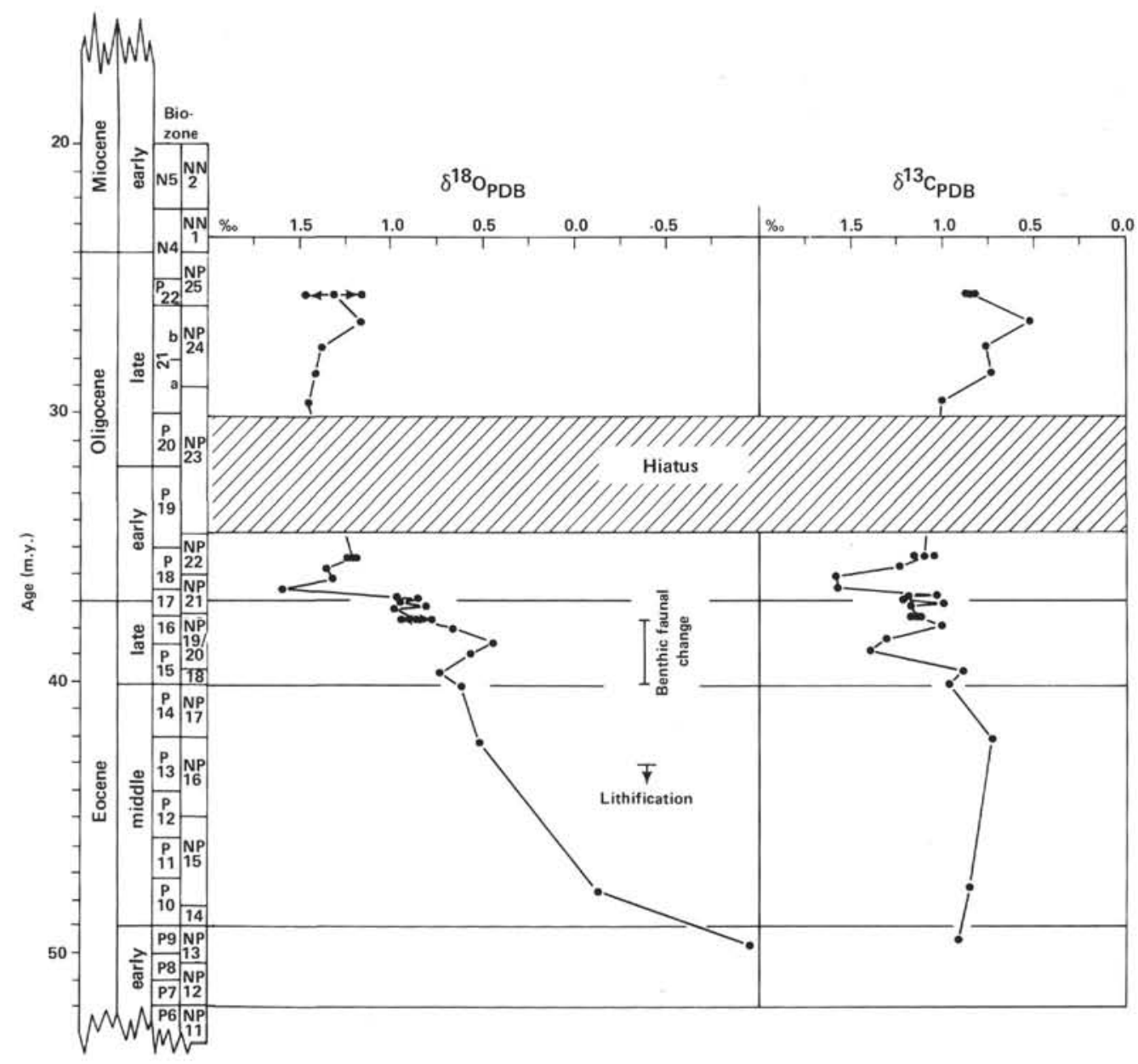

Figure 3. Age vs. benthic foraminiferal isotopic composition, Site 549. Faunal change indicated represents the change from an assemblage characterized by Nuttallides truempyi and Bulimina spp. to one dominated by stratigraphically long-ranging and bathymetrically wide-ranging forms.

dle Eocene. Oridorsalis spp. (mostly $O$. umbonatus), Gyroidinoides spp., Globocassidulina subglobosa, Cibicidoides ungerianus, Pullenia eocenica, and Stilostomella subspinosa are important, stratigraphically longranging, and bathymetrically wide-ranging taxa that are abundant throughout the Eocene and Oligocene (Fig. 9).

Nuttallides truempyi decreases in abundance in the lowermost upper Eocene (between $\sim 40$ and 38.5 m.y. old). The buliminids subsequently increase in abundance, only to decrease in abundance just below the Eocene/ Oligocene boundary ( $\sim 37.5 \mathrm{~m} . \mathrm{y})$.

The replacement of the $N$. truempyi assemblage and the increase and subsequent decrease of the buliminids represent the most important faunal variations in the Eocene to Oligocene section (Fig. 7). We made a $Q$-mode principal-component analysis of the 25 samples from Site 549. Principal component 2 explains $28.2 \%$ of the faunal variation (for the 48 taxa used by Tjalsma and Lohmann, 1983, and Miller, 1983; Table 1) in the Eocene to Oligocene section of Site 549. The N. truempyi assemblage is represented by high negative loadings on principal component 2 (Fig. 7); this assemblage also contains a higher than average abundance of buliminids, Osangularia spp., and Lenticulina spp. High positive loadings on principal component 2 represent the uppermost Eocene through Oligocene assemblage dominated by the long- and wide-ranging taxa ( $G$. subglobosa, $C$. ungerianus, Gyroidinoides spp., $P$. eocenica, and $S$. subspinosa). Low positive loadings on principal component 2 in the upper Eocene (38.5-37.5 m.y.) represent the dominance of the buliminids after the extinction of $N$. truempyi.

Our assemblages compare closely with those identified by Tjalsma and Lohmann (1983). We estimated loadings of Site 549 samples onto Tjalsma and Lohmann's (1983) principal components to determine how these samples compare with the assemblages that they defined. These loadings are components of the sample vectors projected onto the coordinate system defined by Tjalsma's and Lohmann's principal-component analyses of their Eocene samples. The lower to lowermost upper Eocene samples from Site 549 give low to moderate positive loadings on their $Q$-mode principal component 2, and negative loadings on their principal component 3 . This corresponds to the Lenticulina-Bulimina-Osangularia assemblage of Tjalsma and Lohmann. The upper Eocene through Oligocene samples from Site 549 have high positive loadings on Tjalsma's and Lohmann's prin- 
Table 5. Benthic foraminiferal oxygen and carbon isotopic data $(\% 0)$. Site 549.

\begin{tabular}{|c|c|c|c|c|c|}
\hline $\begin{array}{l}\text { Sample } \\
\text { no. }\end{array}$ & $\begin{array}{l}\text { Core-Section, } \\
\text { interval in } \mathrm{cm}\end{array}$ & ${ }_{\delta}^{18} \mathrm{O}$ & $\delta^{13} \mathrm{C}$ & $\begin{array}{l}\text { Nannofossil } \\
\text { zone }\end{array}$ & $\begin{array}{c}\text { Foraminiferal } \\
\text { zone }\end{array}$ \\
\hline \multicolumn{6}{|c|}{ Hole 549A } \\
\hline 1 & $6-6,100-105$ & $\begin{array}{l}1.17 \\
1.47\end{array}$ & $\begin{array}{l}0.83 \\
0.87\end{array}$ & NP24/NP25 & $\mathrm{P} 22$ \\
\hline 2 & $7-6,118-123$ & 1.17 & 0.52 & NP24/NP25 & P21B \\
\hline 3 & $8-6,60-65$ & 1.38 & 0.76 & NP24/NP25 & P21B \\
\hline 4 & $9-6,70-75$ & 1.41 & 0.73 & NP24/NP25 & P21A \\
\hline 5 & $10-6,143-148$ & 1.45 & 1.00 & NP23 & P21A (P20) \\
\hline \multicolumn{6}{|c|}{ Hiatus } \\
\hline 6 & $11-6,143-148$ & $\begin{array}{l}1.22 \\
1.18\end{array}$ & $\begin{array}{l}1.15 \\
1.04\end{array}$ & NP22 & C. chipolensis/P. micra \\
\hline 7 & $13-1,143-148$ & 1.34 & 1.23 & NP22 & C. chipolensis/P. micra \\
\hline 8 & $14-1,116-121$ & 1.31 & 1.58 & NP21 & C. chipolensis/P. micra \\
\hline 9 & $15-1,116-121$ & 1.58 & 1.57 & NP21 & C. chipolensis/P, micra \\
\hline 10 & $16-1,138-141$ & 0.85 & 1.03 & NP21 & C. chipolensis/P. micra \\
\hline 11 & $16-2,24-27$ & 0.96 & 1.18 & NP21 & C. chipolensis/P. micra \\
\hline 12 & $17-1,24-27$ & 0.94 & 1.21 & NP21 & C. chipolensis/P. micra \\
\hline \multicolumn{6}{|c|}{ Eocene/Oligocene boundary } \\
\hline 13 & $17-2,43-45$ & 0.80 & 0.99 & NP21 & G. cerroazulensis cunialensis \\
\hline 14 & $18-1,103-106$ & 0.97 & 1.17 & NP21 & G. cerroazulensis cunialensis \\
\hline 15 & $24-2,126-130$ & $\begin{array}{l}0.77 \\
0.93\end{array}$ & $\begin{array}{l}1.12 \\
1.15\end{array}$ & NP21 & G. cerroazulensis cunialensis \\
\hline 16 & $28-1,143-146$ & 0.65 & 1.00 & NP19/NP20 & G. cerroazulensis cunialensis \\
\hline 17 & $33-1,143-146$ & 0.43 & 1.30 & NP19/NP20 & G. cerroazulensis cocoaensis \\
\hline 18 & $35-1,26-28$ & 0.55 & 1.39 & NP18 & G. cerroazulensis cocoaensis \\
\hline 19 & $38-1,49-53$ & 0.72 & 0.88 & NP18 & $\begin{array}{l}\text { G. cerroazulensis } \\
\text { cerroazulensis }\end{array}$ \\
\hline 20 & $40-1,94-97$ & 0.60 & 0.96 & NP17 (NP18) & $\begin{array}{l}\text { G. cerroazulensis } \\
\text { cerroazulensis }\end{array}$ \\
\hline \multicolumn{6}{|c|}{ Hole 549} \\
\hline 21 & $2-5,126-129$ & 0.50 & 0.72 & & P14 \\
\hline $22^{\mathrm{a}}$ & $4-6,145-148$ & & & & \\
\hline $23^{\mathrm{a}}$ & $6-6,148-150$ & & & & \\
\hline 24 & $8-4,145-147$ & -0.16 & 0.84 & NP15 & P11 \\
\hline 25 & $10-5,57-61$ & -0.99 & 0.90 & NP13 & $\mathrm{P} 9$ \\
\hline
\end{tabular}

Note: All analyses performed on monogeneric Cibicidoides spp.

a Insufficient for analysis.

cipal component 3 and high negative loadings on principal component 2; this corresponds to their G. subglobosa-Gyroidinoides-C. ungerianus-Oridorsalis assemblage.

The replacement of the assemblage dominated by Nuttallides truempyi occurred near the middle/late Eocene boundary in deeper sites in the South Atlantic (Tjalsma and Lohmann, 1983), correlating with its replacement at Site 549. Elsewhere in the Bay of Biscay, a similar timing for the replacement is noted at Site 401 (Fig. 10) ( $\sim 2.0-2.5 \mathrm{~km}$ depositional depth). The records recovered at the shallower Site 548 and the deeper $(>3 \mathrm{~km})$ Sites 119 and 400 are less complete (Fig. 10; fig. 11 in Miller, 1983), but the timing of the faunal replacement at these sites does not contradict the timing observed in the more completely recovered records for Sites 401 and 549 .

Tjalsma and Lohmann (1983) suggested that the replacement of the Nuttallides truempyi assemblage was diachronous, occurring near the early/middle Eocene boundary in "shallow" sites $(<2 \mathrm{~km})$ such as Site 357 . Close inspection of their data shows, however, that Site 357 is the only site at which the replacement occurred at this time (Fig. 11). In both shallower ( $\sim 1.4 \mathrm{~km}$ depositional depth, Conslope borehole) and slightly deeper boreholes ( $\sim 2.0-2.5 \mathrm{~km}$ depositional depth, Sites 94, 363 , and 19), the change occurred near the middle/late Eocene boundary (Fig. 11). The diachrony of the change at Site 357 relative to other locations may have resulted from uplift of that site in the Eocene (D. A. Johnson, pers. comm., 1982), although this would have necessitated uplift above the upper depth-limit of Nuttallides truempyi (believed to be $\sim 500-600 \mathrm{~m}$; Berggren and Aubert, 1976). Within the biostratigraphic error bars assigned here and by Tjalsma and Lohmann (1983), and excluding Site 357 , the replacement of the $N$. truempyi assemblage was synchronous in the North Atlantic, Gulf of Mexico, Caribbean, and South Atlantic.

In the deeper locations ( $>2 \mathrm{~km}$ ) in the North Atlantic (Site 549 and Site 401, Barbados) there is a strong suggestion that Nuttallides truempyi displays two acmes in the Eocene. Peaks in abundance occurred in the early middle and late middle Eocene, and decreased abundances occurred in the middle Eocene and late Eocene (Figs. 10 and 11). Although the replacement of the $N$. truempyi assemblage in the earliest late Eocene may be a useful biostratigraphic event, care must be taken to differentiate this decrease in abundance from the earlier decrease.

No major change in faunal abundance takes place across the Eocene/Oligocene boundary, although the decrease in abundance of the buliminids predates this boundary by $<0.5 \mathrm{~m}$.y. This agrees with the suggestion that the Eocene/Oligocene boundary was not a "catastrophic threshold" for benthic foraminifers (Corliss, 1979a, 1981; Tjalsma and Lohmann, 1983; Tjalsma, 1982; and Miller, 1983).

It is apparent from Figure 12 that several first and last appearances occurred in the late Eocene to earliest Oligocene. Nuttallides umbonifera, Epistominella cf. exigua, and Astrononion pusillum (Plate 5) appeared in the late Eocene; these species constitute important faunal elements of the deep abyssal $(>3 \mathrm{~km}$ depositional depth) Oligocene assemblage at Sites 119, 400, and 550, and their first occurrences in the late Eocene may be useful biostratigraphic levels. Rarer taxa also appeared in the late Eocene at Site 549: Bolivina antegressa, Eggerella bradyi, and Uvigerina elongata. Cyclammina placenta, Karreriella cubensis, Dentalina spp., Fursenkoina spp., and probably Cassidulina havanensis had first occurrences just above the level of the Eocene/Oligocene boundary. Some of these early Oligocene first appearances were local; for example, Karreriella cubensis and C. havanensis both occurred elsewhere in Zone P11 (Tjalsma and Lohmann, 1983).

Several last appearances took place in the late Eocene. Nuttallides truempyi, Cibicidoides sp. 1, Bolivinopsis spectabilis, Gaudryina laevigata, G. pyramidata, G. cf. pyramidata, "Eggerella" sp., and Bulimina macilenta had their last occurrences in the late Eocene, and may therefore provide useful biostratigraphic levels. $\mathrm{Bu}$ limina tuxpamensis and $B$. semicostata had their last occurrences in the late Eocene at Site 549, but elsewhere ranged into the Oligocene (Tjalsma and Lohmann, 1983).

Other important first appearances took place in the early to middle Eocene at Site 549: (1) Gavelinella semicribrata s.s. had its first occurrence consistently in Zone P12 in the Bay of Biscay (Miller, 1983) and elsewhere (Tjalsma and Lohman, 1983) (Plate 7); (2) the first occurrence of G. micra was in Zone P12 at Sites 401 and 


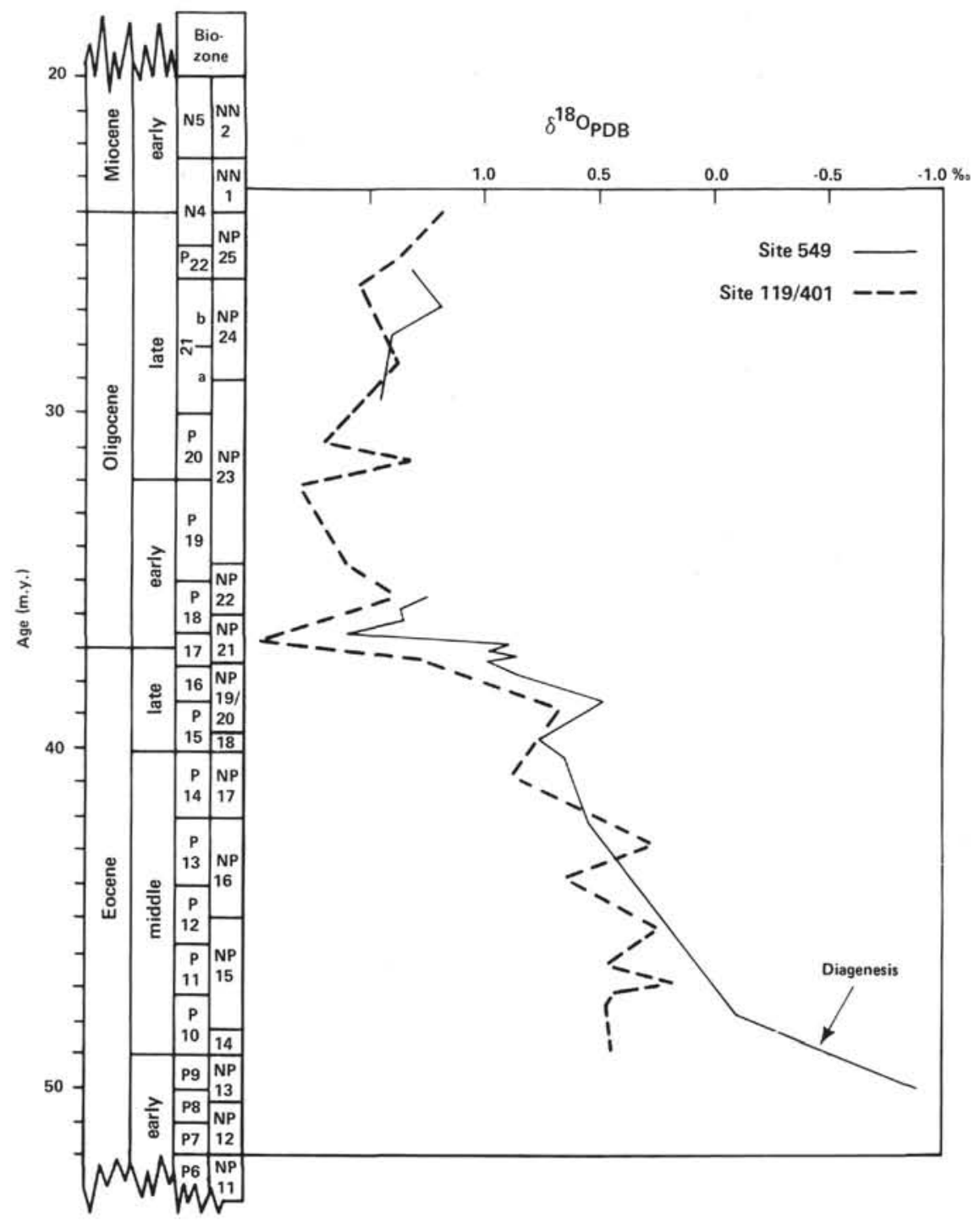

Figure 4. Comparison of Site 549 benthic foraminiferal oxygen isotopic composition with composite record from Bay of Biscay Sites 119 and 401 . (Site 119 and Site 401 data after Miller and Curry, 1982.)

549 (Miller, 1983); elsewhere in the Atlantic, however, the first occurrence predates P12 (Tjalsma and Lohmann, 1983); and (3) Bulimina jarvisi first occurred in Zone P11/P12 at Site 549, in Zone P14 at Site 401 (Miller, 1983), and in Zone P15 in the South Atlantic (Tjalsma and Lohmann, 1982). The apparent diachrony of the appearance of this latter taxon may be due in part to differing taxonomic concepts; for example, Schnitker (1979) noted the first occurrence of B. jarvisi in Zone P6 at Site 401. Upper Oligocene first occurrences (all Zone P21) included Plectofrondicularia sp. and Sphaeroidina bulloides.

\section{Biostratigraphy, Site 548}

The Eocene through Oligocene section at Site 548 was cored with a rotary drill. The biostratigraphic age assignments for both nannofossils (M.-P. Aubry, pers. comm., 1982) and planktonic foraminifers are given in Table 4 and Figure 13. These assignments agree well with those of the site chapter and of Müller (this vol.) and Snyder and Waters (this vol.). A difference in the ages of sediments immediately above the "middle" Oligocene hiatus (see subsequent discussion) (i.e., assigned to Zone NP23, this chapter and to Zone NP24, Müller, this vol.) results from reworking of lower Oligocene (Zone NP23) sediments into upper Oligocene strata (Poag, pers. comm., 1983) (Table 4). The entire middle Eocene through Oligocene section is only $\sim 60 \mathrm{~m}$ thick. Our age-depth plot (Fig. 13) indicates that major hiatuses occur between the lower Eocene and the middle Eocene (between Samples 548A-21-4, 55-58 cm and 548A-22-6, 94-97 cm), the middle Eocene and the upper Eocene (between Samples 548A-17-5, 121-124 cm and 548A-18$3,98-101 \mathrm{~cm}$ ), and the lower Oligocene and upper Oligocene (between Samples 548A-16-3, 66-69 cm and $548 \mathrm{~A}-16-4,66-69 \mathrm{~cm}$ ) (Table 4). A minor hiatus may occur just above the Eocene/Oligocene boundary, for the lower Oligocene portion of Zone NP21 may be missing, 


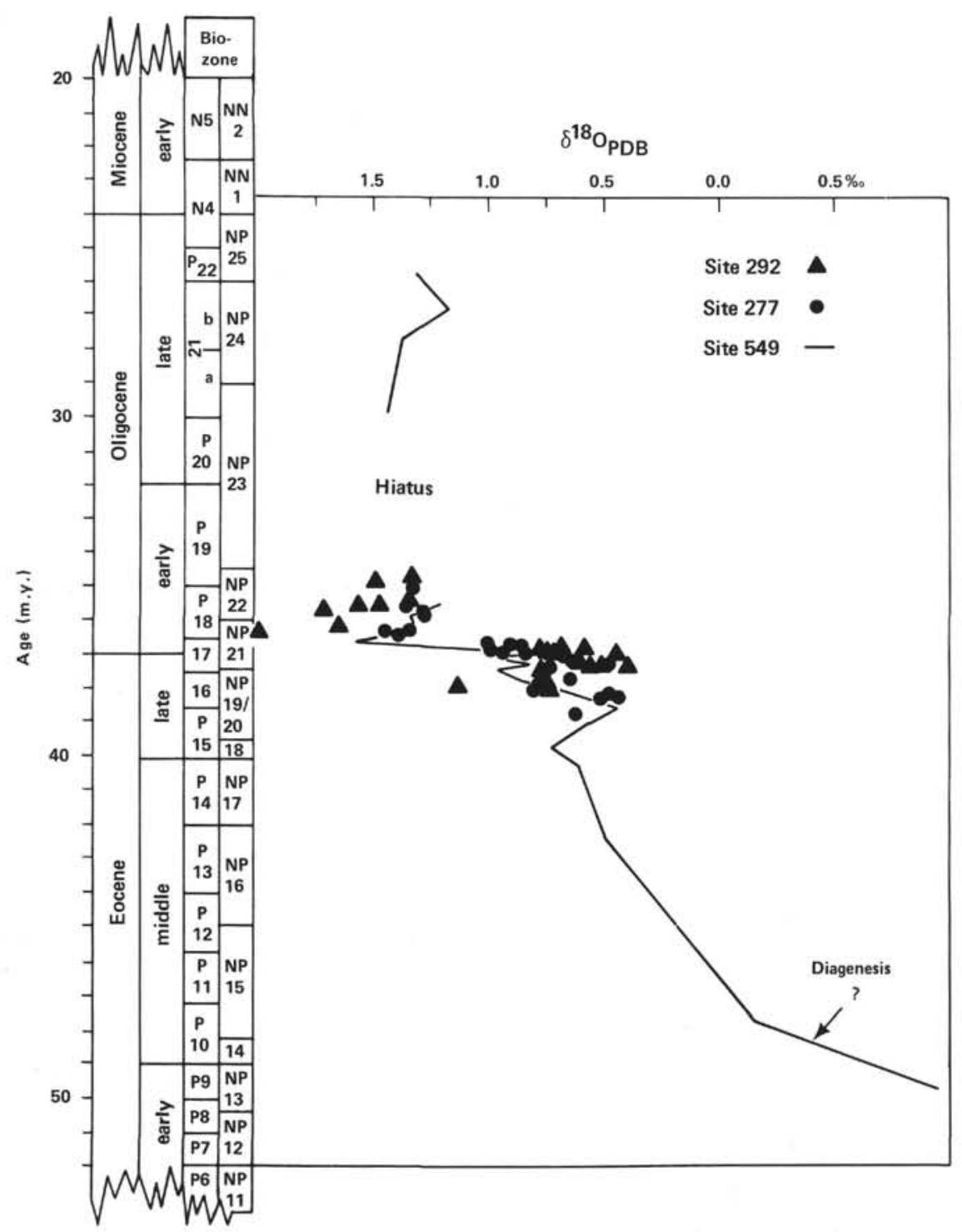

Figure 5. Comparison of Site 549 benthic foraminiferal oxygen isotopic composition with records from Site 277 (Campbell Plateau) and Site 292 (Philippine Sea). Site 277 age control taken by interpolating between tie points at $31.5 \mathrm{~m} . y$. ( $82.5 \mathrm{~m}$ sub-bottom, LAD $S$. angiporoides, Kennett, Houtz, et al., 1975), 37.0 m.y. (188.5 m, Eocene/Oligocene boundary, Keigwin, 1980), and 39.5 m.y. (240.5 m, FAD I. recurvus, Kennett, Houtz, et al., 1975), which results in a constant sediment accumulation rate of $20 \mathrm{~m} / \mathrm{m} . \mathrm{y}$. for the section laid down in the late Eocene to middle Oligocene. Site 292 age control taken by interpolating between 30.0 m.y. (225 m sub-bottom, base of Zone P21, Karig, Ingle, et al., 1975) and 37.0 m.y. (Eocene/Oligocene boundary, Keigwin, 1980) and extrapolating the sediment accumulation rate to the bottom of the section. (Site 277 and Site 292 isotopic data after Keigwin, 1980.)

and the sediment accumulation rates calculated for this section are low $(<3 \mathrm{~m} / \mathrm{m}$.y.). In addition, the sediment accumulation rates computed for the upper Oligocene section are also very low $(\sim 1.0 \mathrm{~m} / \mathrm{m} . \mathrm{y}$.), suggesting that other hiatuses may occur in this thin $(\sim 10-\mathrm{m})$ interval.

The punctuated nature of the Eocene to Oligocene stratigraphic record recovered at Site 548 makes it less desirable for benthic foraminiferal studies. In addition, reworking appears to be more of a problem at Site 548 that at Site 549, for middle Eocene acarininids are found in the overlying upper Eocene and Oligocene sections.

\section{Benthic Foraminiferal Assemblages, Site 548}

As at Site 549, the major Eocene to Oligocene faunal variation at Site 548 was the replacement of the Nuttallides truempyi assemblage. We made a $Q$-mode principalcomponent analysis of 13 samples from Site 548. Principal component 2 explains $38.2 \%$ of the faunal variation (for the 48 taxa used by Tjalsma and Lohmann, 1983, and Miller, 1983; Table 2) in the Eocene to Oligocene section of Site 548. The lower and middle Eocene is dominated by $N$. truempyi and Lenticulina spp. (Figs. 10, 


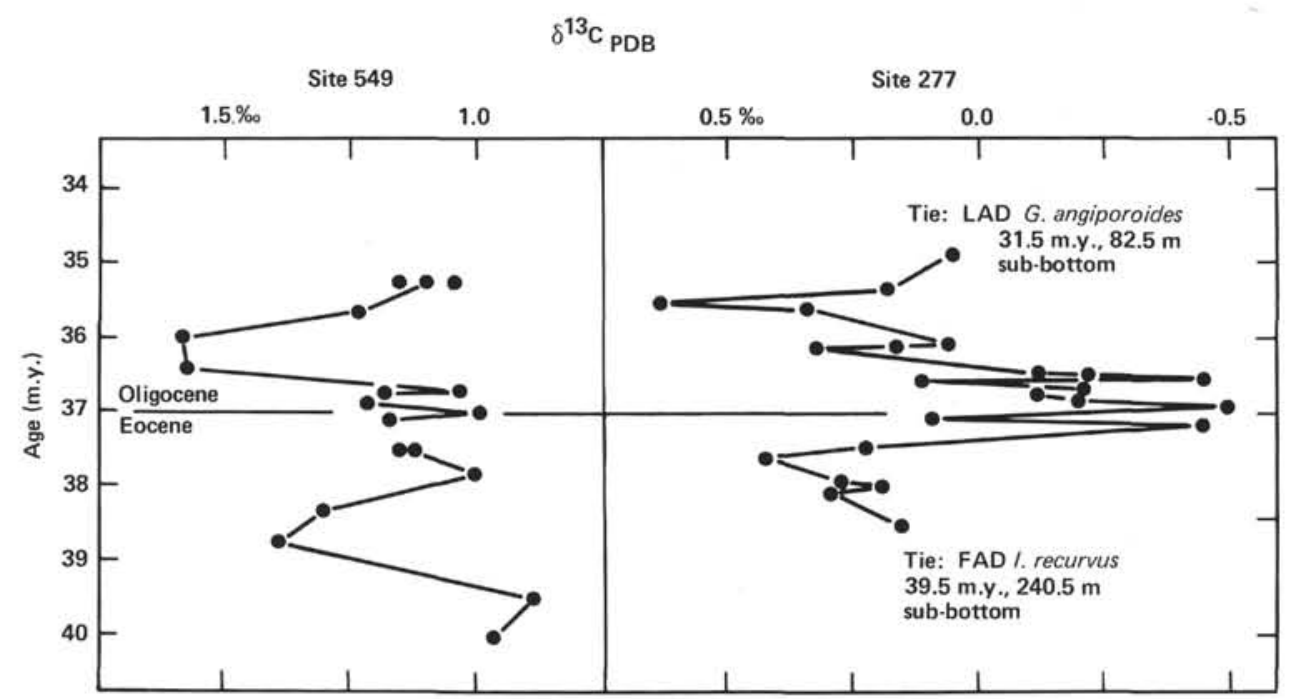

Figure 6. Comparison of Site 549 benthic foraminiferal carbon isotopic composition with record from Site 277 (Campbell Plateau). Age control for Site 277 same as Figure 5.

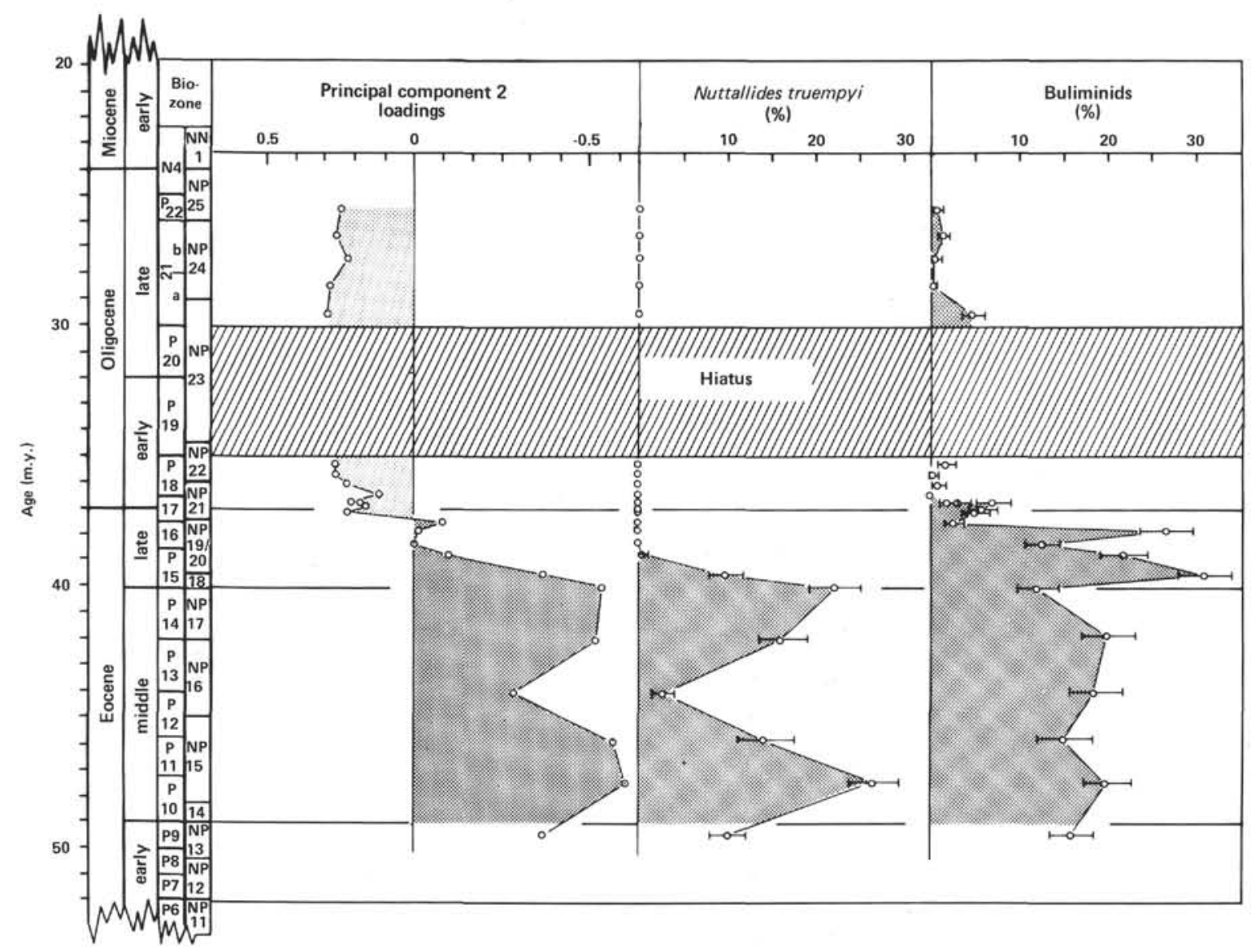

Figure 7. Benthic foraminiferal assemblage composition, Site 549. Principal-component analysis was performed on 25 samples from this site. Error bars on percentages indicate $80 \%$ confidence interval.

14). The $N$. truempyi-Lenticulina assemblage is represented by high negative loadings on principal component 2 (Fig. 14). High positive loadings on principal component 2 represent the upper Eocene through Oligocene assemblage dominated by Gyroidinoides spp., Bulimina alazanensis, and Globocassidulina subglobosa
(Fig. 14). Although the incomplete record at Site 548 prevents firmly dating the transition from the $N$. truempyi-Lenticulina assemblage to the Gyroidinoides- $B$. alazanensis-G. subglobosa assemblage, loadings on principal component 2 show an increase in the upper Eocene (Fig. 14). This suggests that the major faunal change at 


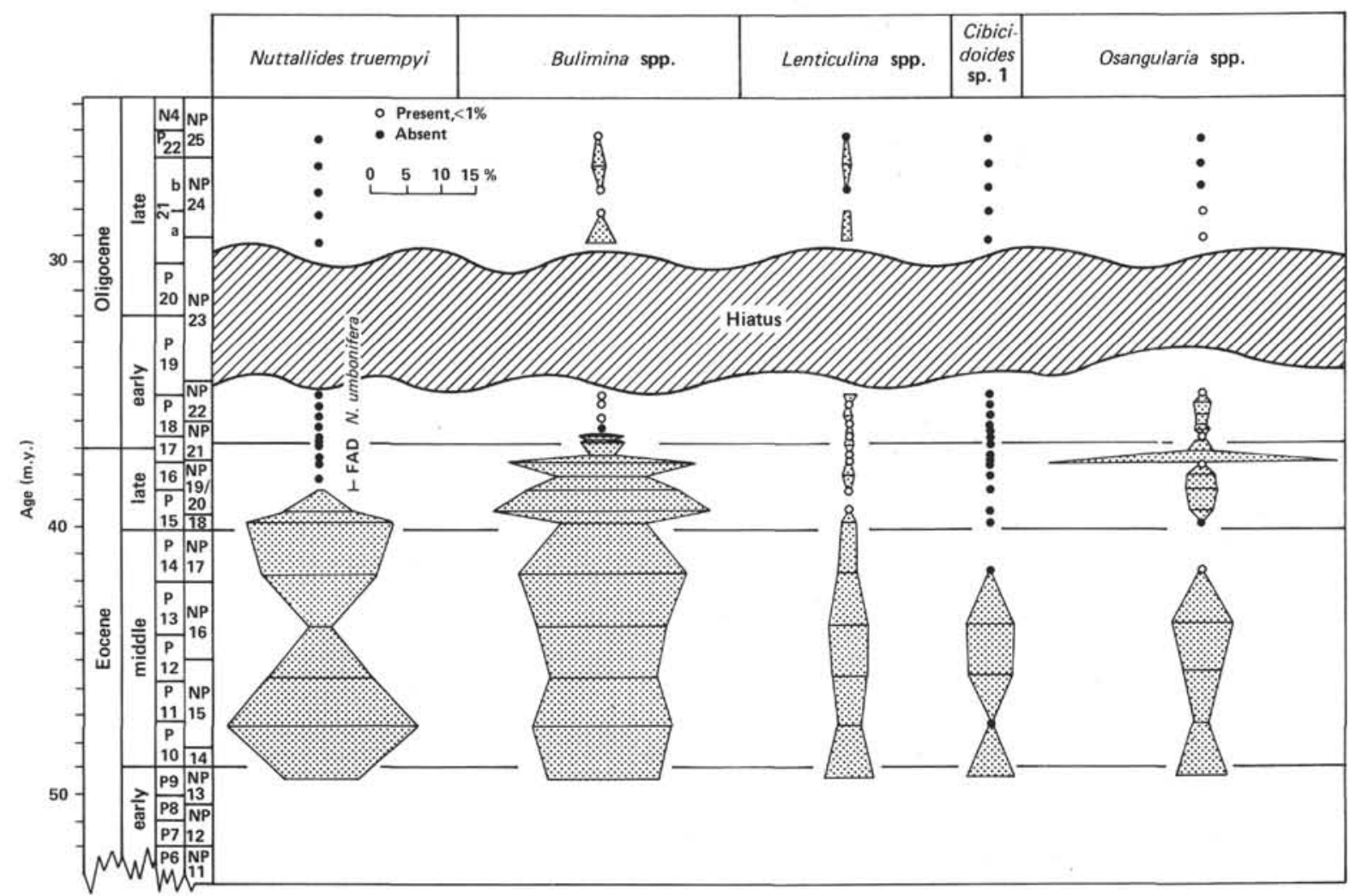

Figure 8. Distribution of dominant benthic foraminifers, Site 549, showing distribution of forms more abundant in the Eocene.

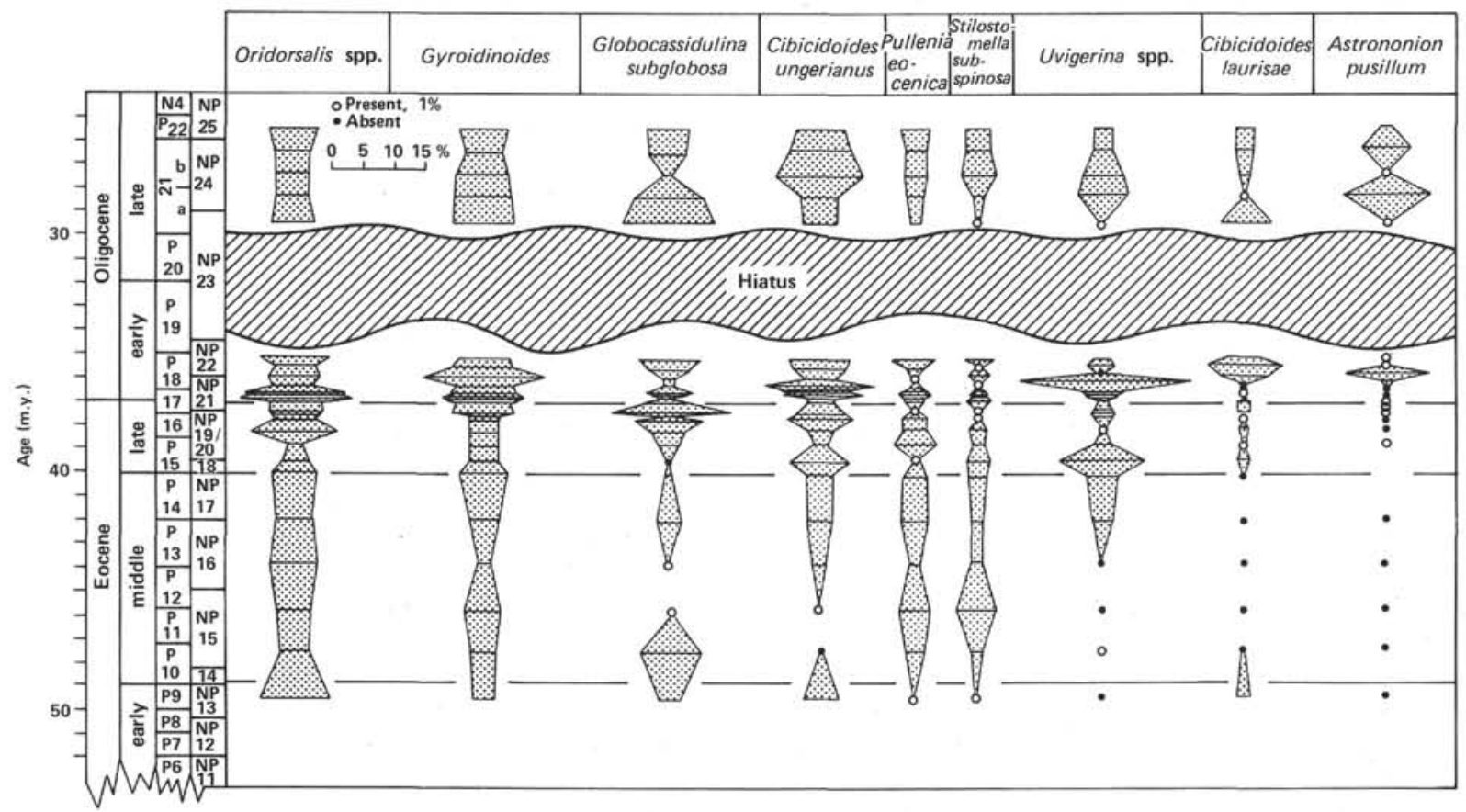

Figure 9. Distribution of dominant benthic foraminifers, Site 549. Shows distribution of stratigraphically long-ranging and bathymetrically wide-ranging taxa that are abundant throughout the Eocene and Oligocene and forms that are more abundant in the Oligocene. 


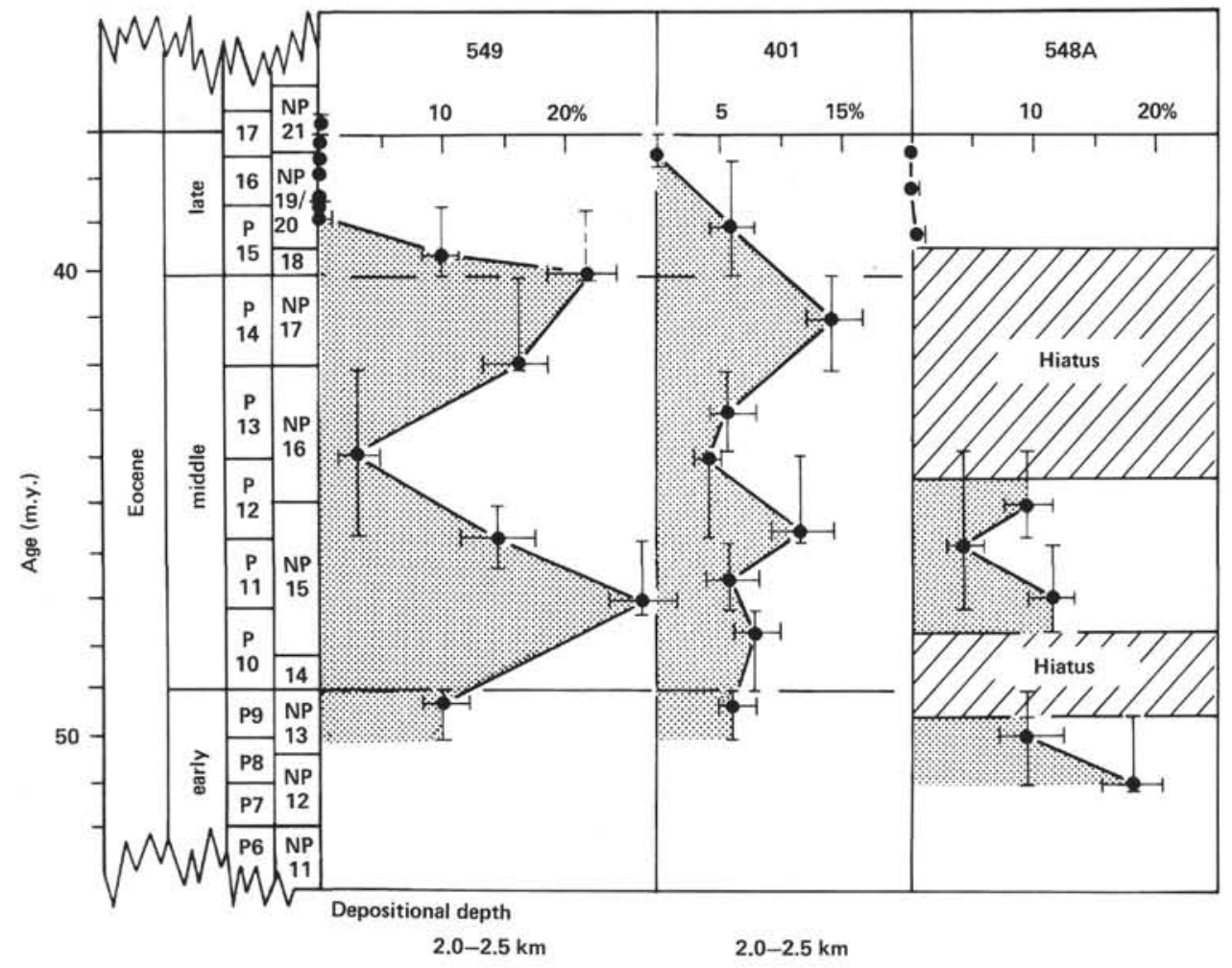

Figure 10. Distribution of Nuttallides truempyi in the Bay of Biscay, Sites 549, 401, and 548 (Hole 548A). Error bars on percentages indicate $80 \%$ confidence interval.

Site 548 began just above the middle/late Eocene boundary, and is therefore coincident with the faunal replacement of the $N$. truempyi-dominated assemblage at Site 549 (Fig. 10).

\section{Biostratigraphy and Benthic Foraminifers, Site $\mathbf{5 5 0}$}

The middle Eocene through Oligocene section (all cored with rotary drill) recovered at the deep Site 550 (4432 m water depth) occurs between $\sim 306$ and $320 \mathrm{~m}$ sub-bottom (site chapter; Fig. 15). Examination of this section reveals it to be very disturbed. Planktonic foraminiferal assemblages show evidence of contamination by Plio-Pleistocene and Cretaceous forms. In addition, planktonic foraminifers, nannofossils, and benthic foraminifers (Plate 7, figs. 6-12) all show evidence of strong dissolution.

An unconformity probably occurs at $\sim 309.5 \mathrm{~m}$ subbottom. The hiatus separates the Oligocene from the Eocene; biostratigraphic resolution of the age of sediments above and below the disconformity is lacking, although it appears to separate middle Oligocene from upper Eocene strata (see discussion following; Figs. 15 and 16). Another hiatus, separating upper Eocene from middle Eocene strata, may occur somewhere in the interval between 311 and $316 \mathrm{~m}$ sub-bottom.

Planktonic foraminiferal age assignments for the Eocene to Oligocene section at Site 550 are confused. Middle Eocene planktonic foraminifers occur in Samples $550-25-1,117 \mathrm{~cm}$ through 550-24-5, $56 \mathrm{~cm}$, whereas Sample $550-24-4,134 \mathrm{~cm}$ contains abundant Globorotalia opima nana, indicative of post-middle Eocene. However, the overlying samples $(550-24-4,101 \mathrm{~cm}$ through $550-24-1,144 \mathrm{~cm}$ ) contain middle Eocene planktonic foraminifers (Acarinina cf. aspensis, $A$. densa, A. cf. pentacamerata, $A$. cf. broedermani). On the basis of its nannofossils, the entire interval between Samples 550$25-1,117 \mathrm{~cm}$ and $550-24-2,144 \mathrm{~cm}$ is assignable to the lower middle Eocene (M.-P. Aubry, pers. comm., 1982) (Fig. 15).

Benthic foraminifers may be used in sorting out the confused stratigraphy of Site 550 (Fig. 15). Nuttallides truempyi dominates the benthic foraminiferal assemblages between 311 and $320 \mathrm{~m}$ sub-bottom; a decrease in abundance of $N$. truempyi occurs between $\sim 316 \mathrm{~m}$ and $311 \mathrm{~m}$ sub-bottom. This decrease can be interpreted in at least three ways: (1) it may represent the transition from the $N$. truempyi-dominated assemblage to the OridorsalisGyroidinoides-G. subglobosa-C. ungerianus assemblage that occurred near the middle/late Eocene boundary at Site 549; (2) it may represent the decrease in abundance of $N$. truempyi that occurred in the early middle Eocene at Site 549; or (3) it may represent a mixing interval, resulting from bioturbation or core disturbance. Several last appearances of benthic foraminiferal taxa that occurred elsewhere near the middle/late Eocene boundary (Fig. 15) are recorded in Sample 550-24-2, $144 \mathrm{~cm}$, suggesting that this decrease in abundance represents the middle/late Eocene boundary. The nannofossil evidence (M.-P. Aubry, pers. comm., 1982) suggests, however, that this decrease in abundance represents the early middle 


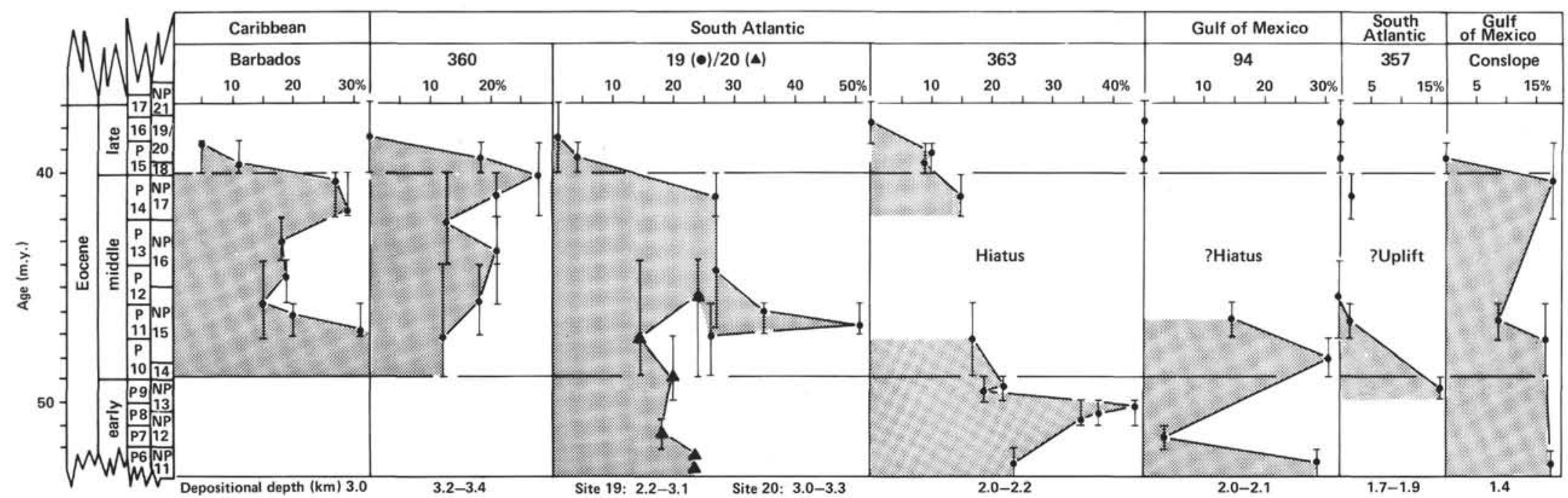

Figure 11. Distribution of Nuttallides truempyi in the South Atlantic, Gulf of Mexico, and Caribbean Sea. (Data after Tjalsma and Lohmann, 1983). Error bars on percentages indicate $80 \%$ confidence interval. 
K. G. MILLER, W. B. CURRY, D. R. OSTERMANN

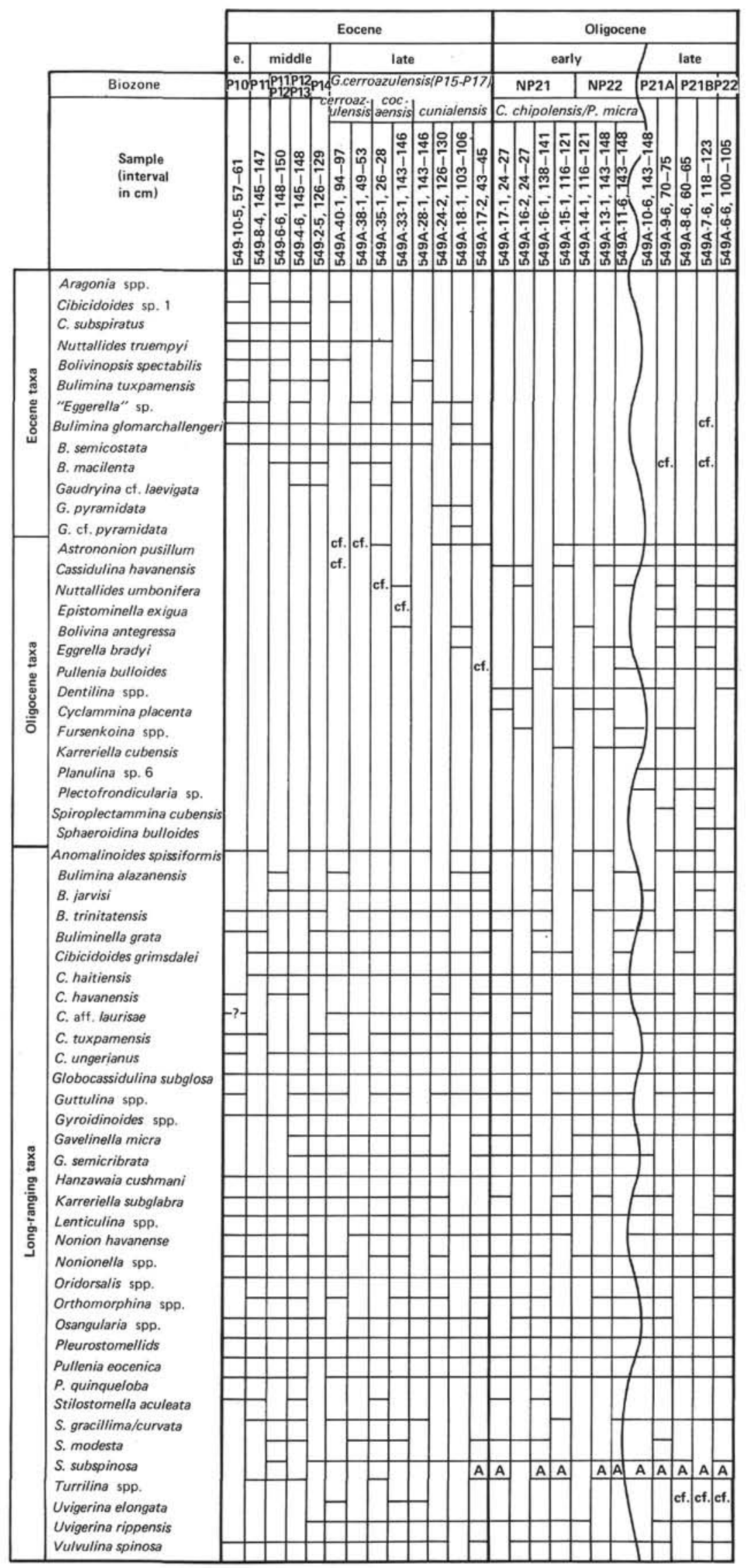

Figure 12. Range chart, Site 549. A = Turrilina alsatica . 


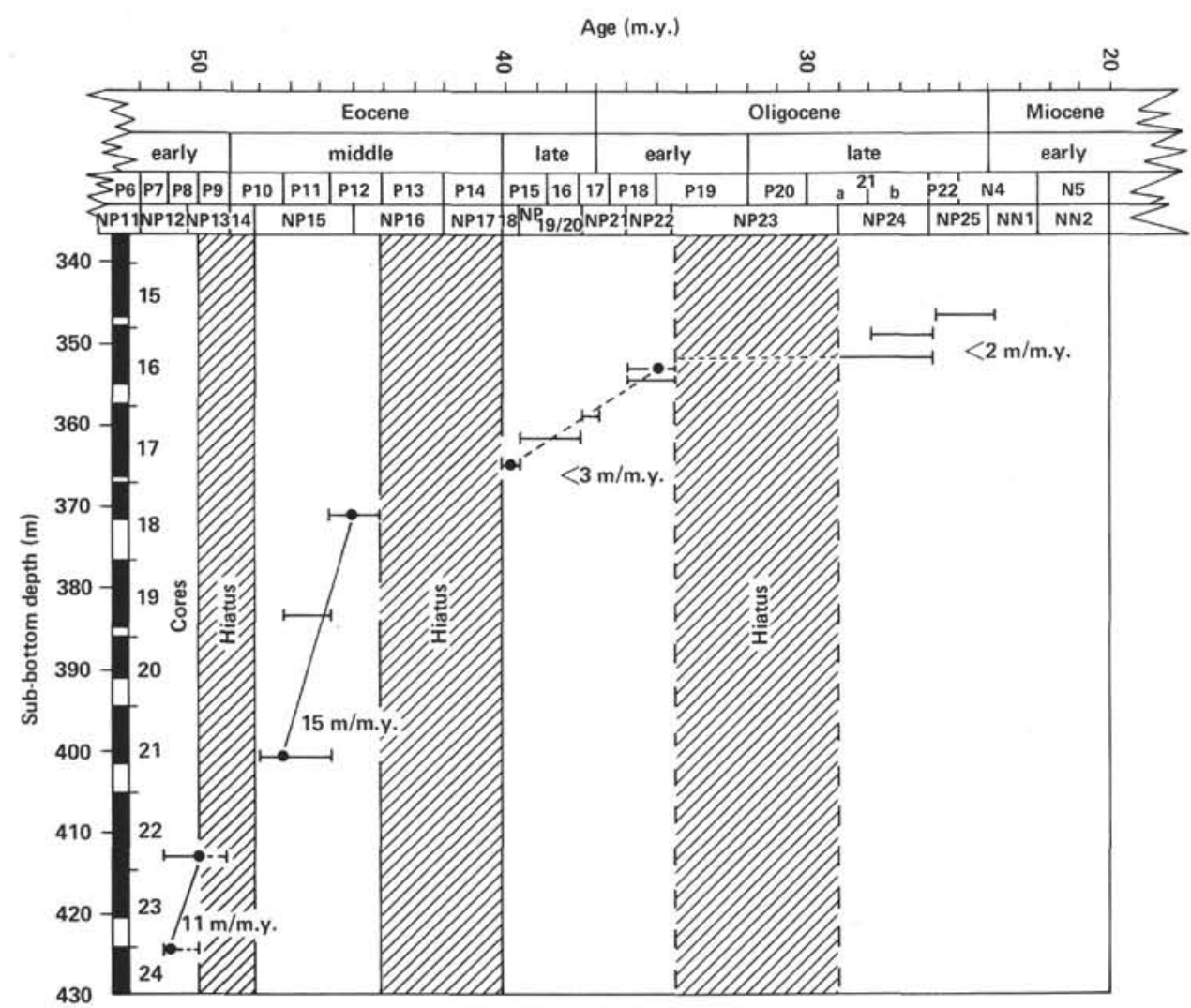

Figure 13. Zonal age assignments and estimated average sediment accumulation rates, Site 548 (Hole $548 \mathrm{~A}$ ). Error bars indicate the length of the biozone(s) to which the sample have been assigned (Table 4). Solid dots indicate ties for interpolating estimates of sediment accumulation rate and age.

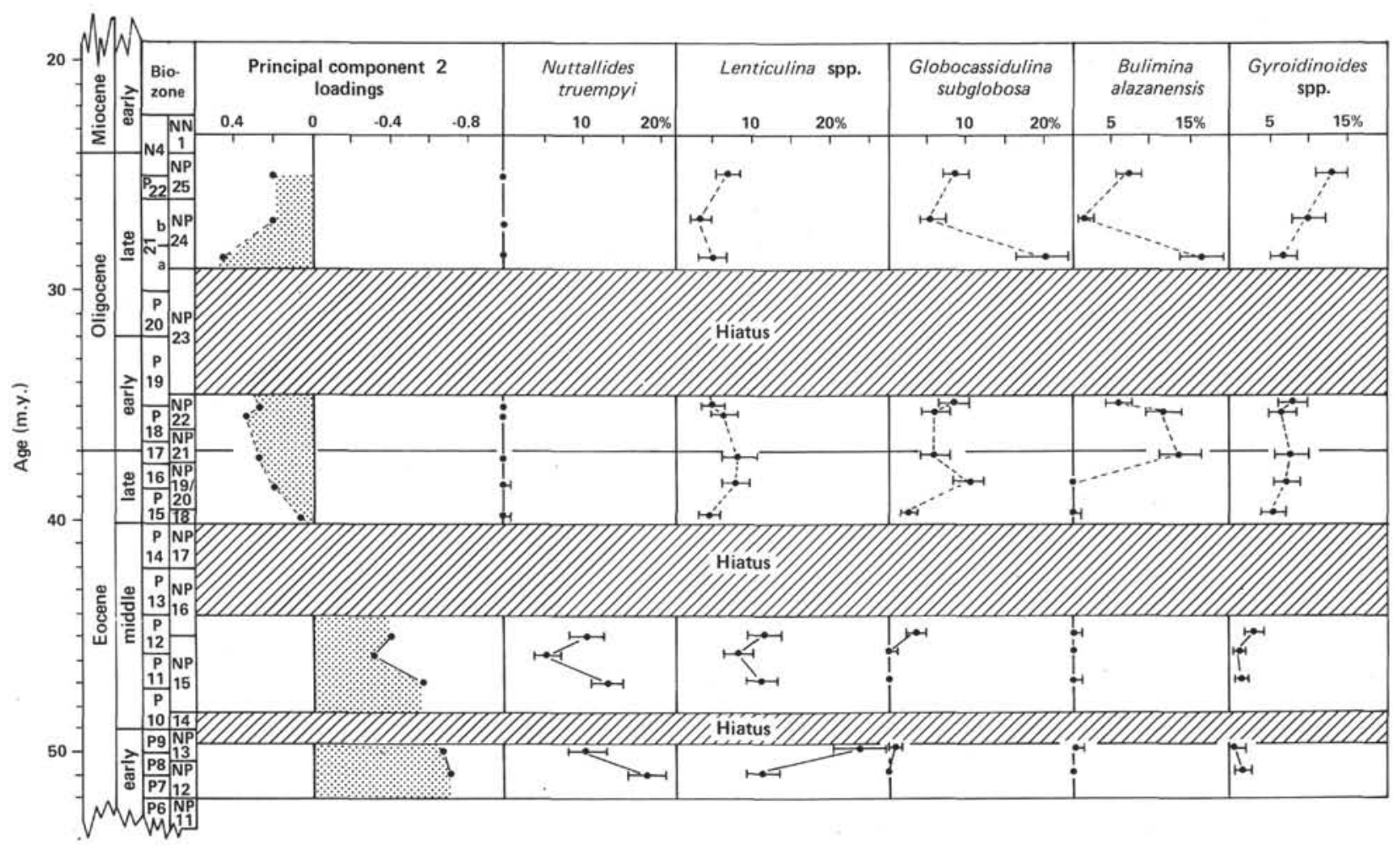

Figure 14. Benthic foraminiferal assemblage composition, Site 548. Principal-component analysis was performed on 13 samples from this site. Error bars on percentages indicate $80 \%$ confidence interval. 


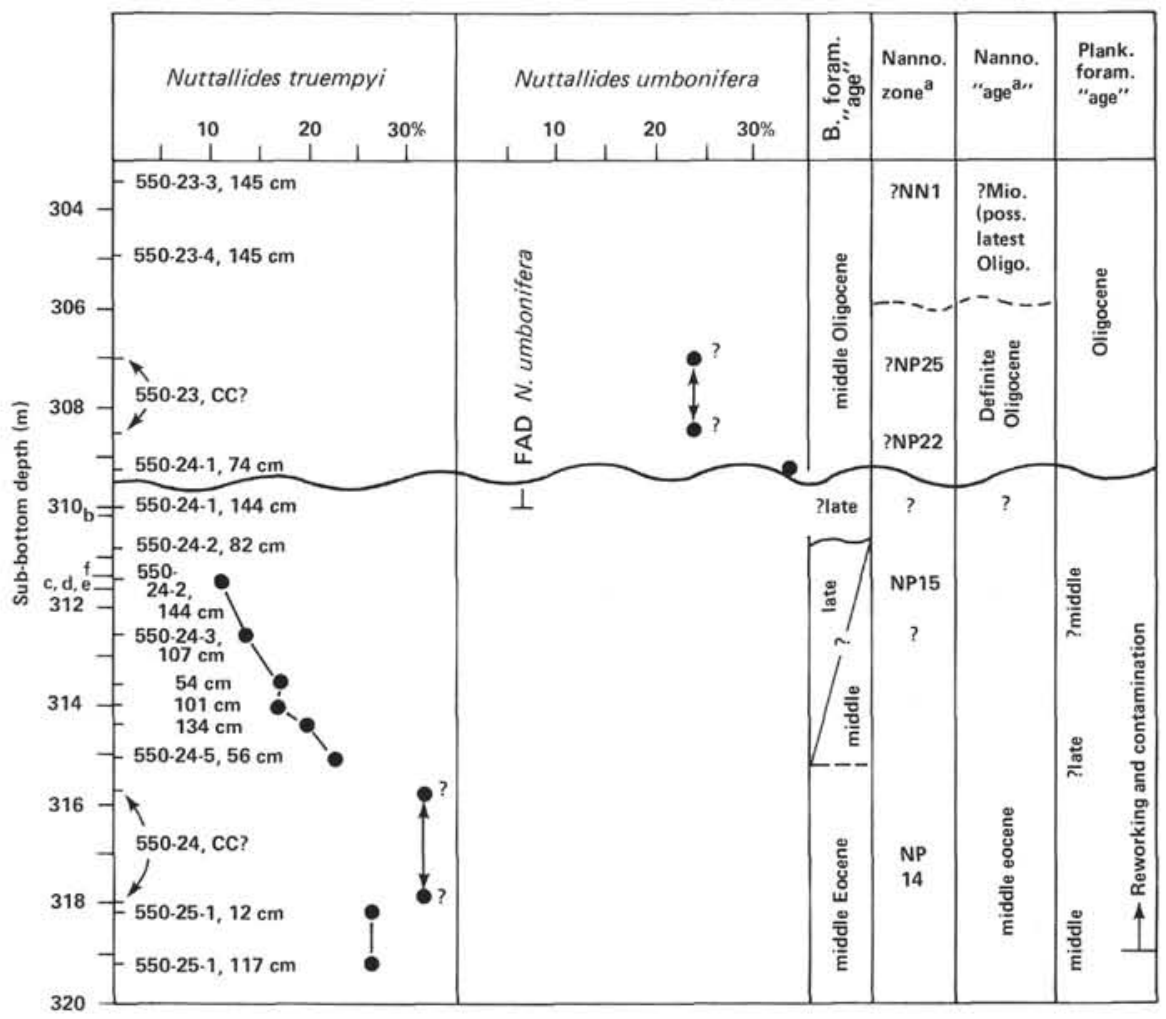

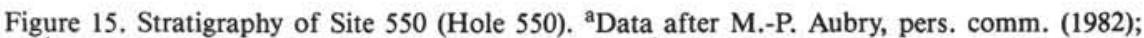
${ }^{b}$ LAD Abyssamina spp.; ${ }^{c}$ LAD Clinapertina spp.; ${ }^{\mathrm{d}}$ LAD Gaudryina pyramidata; ${ }^{\mathrm{e}}$ LAD Alabamina dissonata; ${ }^{\mathrm{f}} \mathrm{FAD}$ Gavelinella semicribrata.

Eocene decrease and that the last occurrences of benthic foraminiferal taxa are truncated at this site. The poor record at this site precludes further resolution.

The overlap of Nuttallides umbonifera (FAD late Eocene) and Abyssamina spp. (LAD late Eocene; Tjalsma and Lohmann, 1983) suggests that Sample 550-24-1, $144 \mathrm{~cm}$ is upper Eocene. However, considering the disturbance noted here, this conclusion remains tentative.

Nuttallides umbonifera occurs in high $(>20 \%)$ abundance in Samples 550-24-1, $74 \mathrm{~cm}$ and 550-23,CC. An acme of this species was noted at the nearby Sites 119 and 400 in the middle Oligocene (Miller, 1983), suggesting that these samples are middle Oligocene. This is consistent with the nannofossil and planktonic foraminiferal evidence.

\section{The Eocene/Oligocene Boundary and Benthic Foraminifers}

Our data from Site 549 definitively show the nature and timing of the major Eocene to Oligocene benthic foraminiferal assemblage changes at intermediate depths $(\sim 2 \mathrm{~km})$ in the Norti Atlantic. At both Site 549 and Site 548, the major faunal change was the replacement of the Nuttallides truempyi assemblage just above the middle/late Eocene boundary; this can be shown to have occurred throughout the North Atlantic, South Atlantic, Caribbean, and Gulf of Mexico at this time. Other faunal changes recorded at Site 549 include (1) a series of extinctions and local last appearances of taxa in the late Eocene; (2) a series of first appearances (some of which were local) in the late Eocene to earliest Oligocene; and (3) the replacement of a buliminid assemblage just below the Eocene/Oligocene boundary.

The most dramatic faunal change occurred not at the shallow and intermediate depths but at the deeper ( $>3 \mathrm{~km}$ depositional depth) sites $(119,400$, and 550). Dominant Nuttallides truempyi, Clinapertina spp., and Abyssammina spp. (together with Alabamina dissonata, Aragonia spp., and other elements of the endemic deep-Eocene assemblages) became extinct between the middle Eocene and the Oligocene; they were replaced by an increasing abundance of wide- and long-ranging taxa (Miller, 1983).

The debate over "terminal Eocene" benthic foraminiferal changes is to some degree a semantic problem. No "crisis" (Kennett and Shackleton, 1976) or "peak in faunal turnover" (Schnitker, 1979) is associated with the level of the Eocene/Oligocene boundary in the size-fraction studied. Major benthic foraminiferal changes occurred, however, between the middle Eocene and the early Oligocene (Corliss, 1979b, 1981; Tjalsma, 1982; Tjalsma and Lohmann, 1983; Miller, in press; this chapter). The data presented here suggest that faunal changes occurred at intermediate depths throughout the late Eocene to earliest Oligocene. Certainly the material studied (depending upon recovery, preservation, geographic location, and depositional depth) and the approach in analysis can affect the perceptions and conclusions drawn as to the timing of the faunal change. (Considerations 
regarding the analytical approach would include the sizefraction studied; whether ranges or abundances were studied; whether $R$-mode or $Q$-mode principal-component, factor, or cluster analyses were employed; and whether plotting was against time or against depth.) Corliss (1979b, 1981), Tjalsma (1982), Tjalsma and Lohmann (1983), Miller (1983) and this study are in agreement, nonetheless, that a series of faunal changes occurred in benthic foraminifers between the middle Eocene and the early Oligocene, although the timing of the changes at the deepest sites ( $>3 \mathrm{~km}$ depositional depths) is poorly constrained in all these studies.

Major benthic faunal changes also occurred in the late Paleogene in ostracodes. Between the middle Eocene and the early Oligocene, the modern cold-water ostracode fauna developed; this has been attributed to the development of cold bottom-water circulation and the associated development of the oceanic cold-water sphere (= psychrosphere) (Benson, 1975). Ducasse and Peypouquet (1979) similarly noted that the psychrospheric ostracode fauna appeared in the late Eocene at Site 406 (southwest margin of Rockall Plateau). The exact timing of the change in ostracodes is debatable (compare Benson, 1975, with Corliss, 1981); it is clear, however, that between the middle Eocene and the early Oligocene, benthic faunas, both ostracodes and foraminifers, underwent a major reorganization.

The relationship of the benthic foraminiferal isotopic and assemblage changes is well defined at Site 549. The faunal changes began $\sim 1 \mathrm{~m}$.y. before the $1 \%$ oxygen isotopic enrichment, which occurred between $\sim 38.5$ and 36.5 m.y. ago (late Eocene to earliest Oligocene). However, the decrease in abundance of Nuttallides truempyi (Figs. 7, 8, 10) was coincident with an increase in $\delta^{13} \mathrm{C}$ ( $\sim 0.5 \%$; $\sim 38-40$ m.y. ago; Figs. 3 and 6$)$.

Benthic foraminiferal $\delta^{13} \mathrm{C}$ values subsequently decreased in the late Eocene, while $\delta^{18} \mathrm{O}$ values increased $\sim 0.3 \%$. These isotopic fluctuations occurred coevally with fluctuations in abundance (Figs. 8 and 9) and with several first and last appearances of taxa (Fig. 12), some of which were local. Upsection from the sharp increases in both $\delta^{18} \mathrm{O}$ and $\delta^{13} \mathrm{C}$ just above the Eocene/Oligocene boundary at Site 549, the benthic foraminiferal assemblages are dominated by taxa that may be interpreted as tolerant of environmental changes (e.g., the bathymetrically wide-ranging and stratigraphically long-ranging Globocassidulina subglobosa, Gyroidinoides spp., Cibicidoides ungerianus, Oridorsalis umbonatus, Pullenia eocenica, and Stilostomella subspinosa; Fig. 9). We concur here with Corliss (1981), who suggested that late $\mathrm{Pa}$ leogene deep-sea benthic foraminifers, in general, may have had wide environmental tolerances. This is further illustrated by the many taxa that range throughout the Eocene to Oligocene section (Fig. 12), despite changes in abyssal circulation inferred from the isotopic, lithologic, and seismic stratigraphic records. For this reason it may be that the greatest isotopic changes, the earliest Oligocene ${ }^{18} \mathrm{O}$ and ${ }^{13} \mathrm{C}$ enrichments, were not associated with the greatest faunal abundance change, viz. the replacement of the Nuttallides truempyi assemblage.
With the resolution provided by Site 549 data, we can compare the changes in faunal isotopic and assemblage composition with the circulation model of Miller and Tucholke (1983). The benthic foraminiferal and isotopic evidence points toward the development of abyssal circulation over a period of several million years (between $\sim 40$ and 36.5 m.y. ago). The change from sluggish to vigorous, intense bottom-water circulation can be dated from the seismic record in the Rockall region as late Eocene to earliest Oligocene (Miller and Tucholke, 1983). Owing to uncertainties in the correlation of Reflector $\mathrm{R} 4$, the circulation change associated with Reflector R4 could correlate with the late Eocene to earliest Oligocene isotopic changes or the benthic foraminiferal assemblage changes. Roberts (1975) and Miller and Tucholke (1983) have suggested that Reflector R4 dates from the latest Eocene to the earliest Oligocene $(\sim 38$ 36 m.y. ago), and that the circulation event associated with this horizon was a geologically rapid event, although uncertainties in the biostratigraphy and the correlation of Reflector R4 with data for the various boreholes prevent absolutely establishing this. If this age assignment is correct, Reflector R4 and the associated circulation change correlate with the major ${ }^{18} \mathrm{O}$ enrichments, but postdated the initial faunal changes.

Our suggestion that the faunal and isotopic changes in the North Atlantic may be attributed to the influx of cold, northern sources of bottom water may be debated, in view of the isotopic and stratigraphic records from other basins. The faunal and isotopic changes discussed here have been noted in samples from several different ocean basins over a wide range of depositional depths. The interpretation that the North Atlantic had an Oligocene northern source of bottom water is derived, however, from the seismic stratigraphic record (Miller and Tucholke, 1983), and does not rely upon faunal and isotopic data. Reflector R4, which is associated with the initiation of more vigorous bottom-water circulation, is found in bathyal (e.g., the Hatton-Rockall Basin) through abyssal locations, indicating influence of northern sources of bottom water over a wide range of depths in the North Atlantic. Southern bottom-water influences on the northeast North Atlantic were probably minimal owing to the restriction of flow from the south by the Azores-Biscay Rise (Fig. 1), Azores-Gibraltar Rise, and Madeira-Tore Rise (Miller and Tucholke, 1983). Still, evidence of widespread unconformities in the Southern and Pacific oceans (Moore et al., 1978) supports the idea that these basins had a southern (Antarctic) source of Oligocene bottom water, as suggested by Kennett and Shackleton (1976). We speculate that both northern and southern sources of cold bottom water began near the end of the Eocene; this is evinced in a synchronous increase in benthic foraminiferal $\delta^{18} \mathrm{O}$. The synchronous ${ }^{18} \mathrm{O}$ enrichment associated with cold bottom-water formation in both the Antarctic and in the polar/subpolar marginal basins of the North Atlantic may have resulted from the formation of southern bottom-water sources after the tectonically controlled entry of northern sources of bottom water into the North Atlantic (Miller, 1982). 


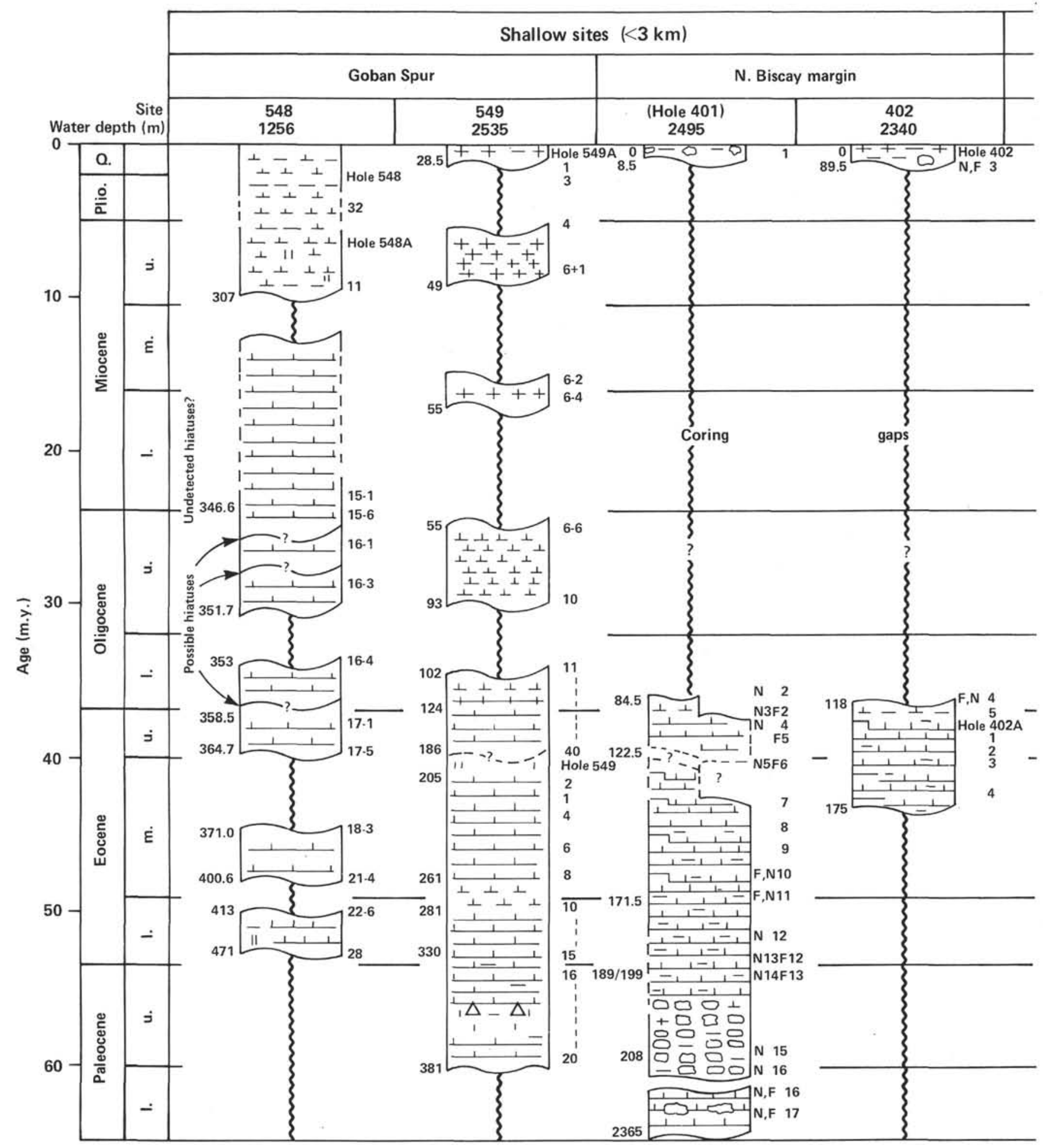

Figure 16. Age vs. lithofacies for Tertiary sediments recovered at DSDP sites in the Bay of Biscay. Site locations in Figure 1. Lithologic symbols follow standard DSDP format. To left of columns are sub-bottom depth in meters (T.D. = total depth); to right are indicated core or section numbers and fossil groups $(\mathrm{F}=$ planktonic foraminifers, $\mathrm{N}=$ nannofossils, $\mathrm{R}=$ radiolarians, $\mathrm{BF}=$ benthic foraminifers) upon which age assignments are based. ( $\mathrm{N}=$ nannofossils; $\mathrm{F}=$ planktonic foraminifers; $\mathrm{BF}=$ benthic foraminifers; $\mathrm{R}=$ radiolarians.) Heavy wavy line indicates hiatuses; dashed lines indicate inferred continuous sedimentation; $\mathrm{X} / \mathrm{S}=$ interpolation of sedimentation rates.

\section{Distribution of Hiatuses in the Bay of Biscay and Goban Spur Regions}

A major middle Oligocene hiatus occurs at Site 548 (Poag et al., this vol.) and probably at Site 549 (this chapter; Müller, this vol.). A similar hiatus may occur at Sites 401 and 402 on the Armorican Margin (Fig. 17). Coring gaps prevent constraining the timing at Sites 401 and 402, however, and the hiatus there may correlate with a hiatus associated with the Eocene/Oligocene bound- 


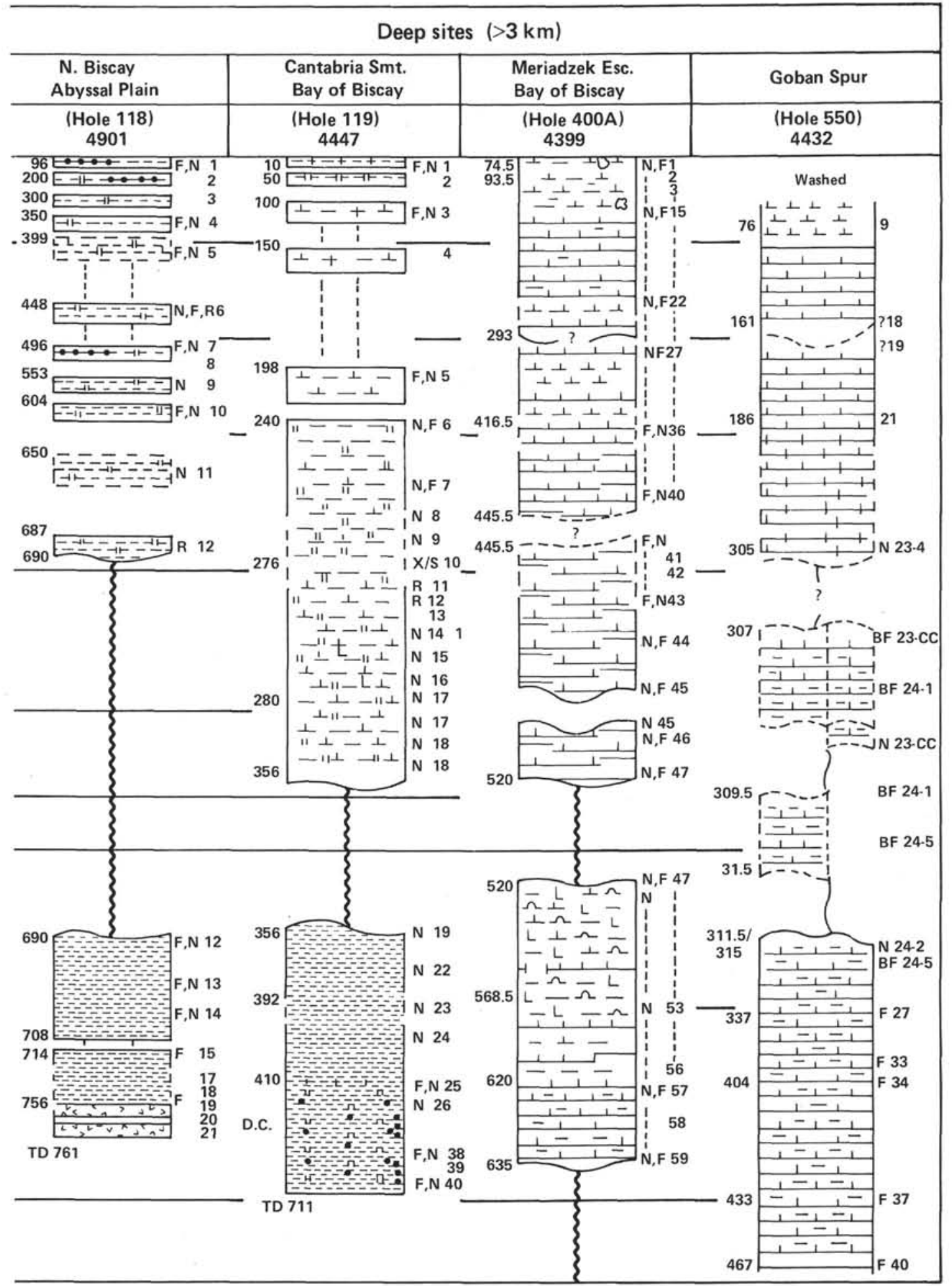

Figure 16. (Continued).

ary at Sites $119,400,550$, and possibly 548 . A middle Oligocene hiatus probably occurs at the deep Site 400; although the Oligocene of the deep Site 119 is apparently continuous, the biostratigraphic control is poor enough that a minor hiatus may lie undetected (Miller, 1983).

The middle Oligocene hiatus is found predominantly at "shallow" sites (Sites 549, 401/402: 2-2.5 km depo- sitional depth; Site 548: $\sim 1.0 \mathrm{~km}$ depositional depth) (Fig. 17), although the unconformity probably occurs to deep sites. This hiatus is coeval with a major middle Oligocene (basal Zone P21A; 29 m.y.) sea-level lowering indicated by Vail et al. (1977), but it is not clear whether the two are related. The hiatuses cannot have resulted from subaerial exposure, for this would have required kilometers of uplift (or sea-level fall) and immediate sub- 


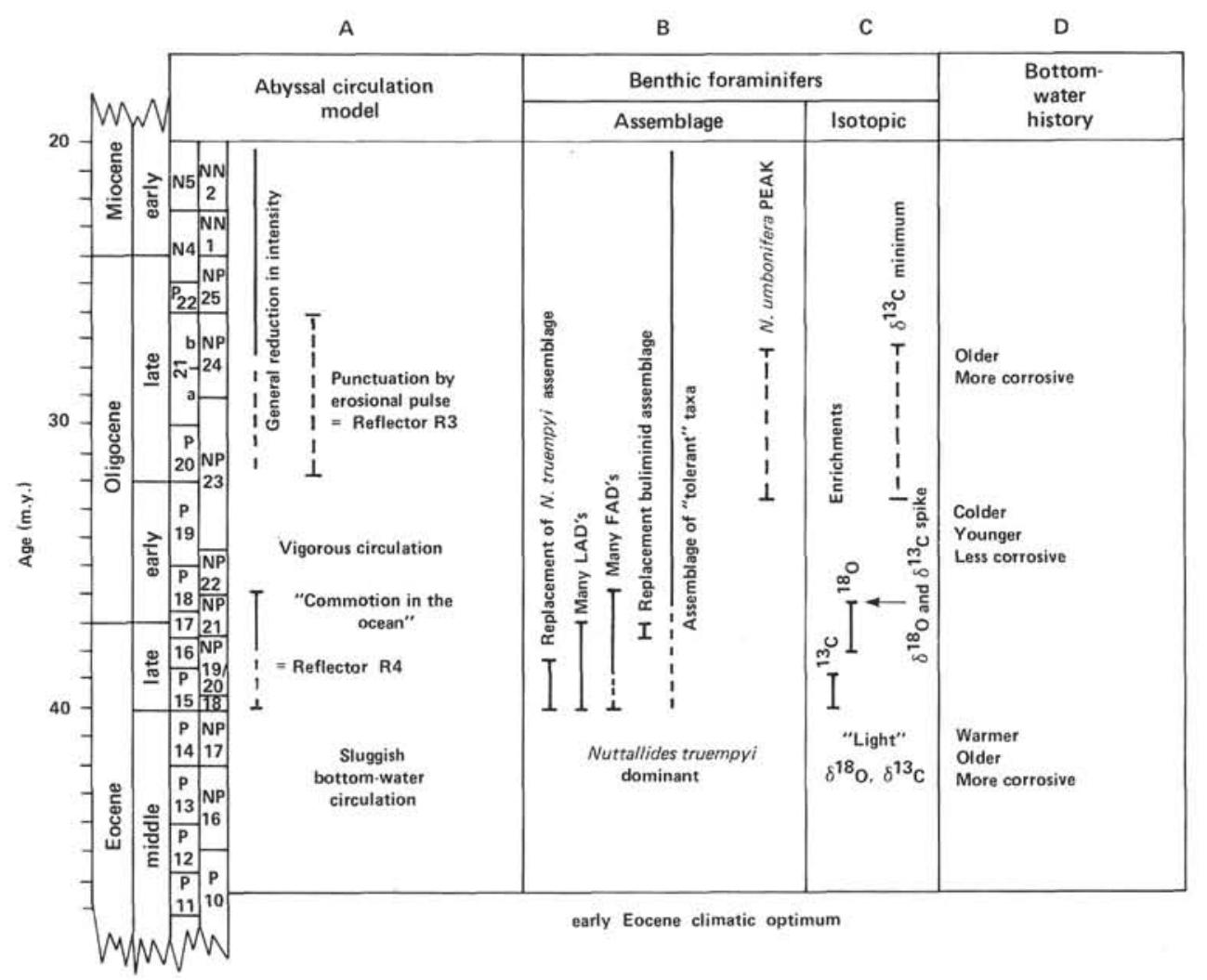

Figure 17. Summary of paleoceanographic events. Column A indicates abyssal circulation events inferred from seismic stratigraphic studies of Miller and Tucholke (1983), column B indicates benthic foraminiferal assemblages and timing of changes, column $\mathrm{C}$ indicates timing of major benthic foraminiferal isotopic events, and column D indicates bottom-water history inferred from the data in columns B and C. The middle Oligocene faunal and isotopic events are taken from Miller and Curry (1982) and Miller (1983); the early Eocene climatic optimum is taken from Haq (1981).

sidence (or sea-level rise). Vail et al. (1977) suggested that deposition during sea-level lowstands (e.g., the middle Oligocene) results in lowstand deposits in deep-marine basins. Thus, deposition, and not the development of hiatuses, might be expected at these intermediate depths during lowstands (Tucholke, 1981). Alternative possible causes of the middle Oligocene hiatus include (1) the increased downslope erosion that occurs during lowstands (Vail et al., 1977), an interpretation that we favor; (2) interruption of sedimentation by tectonism associated with the Pyrenean orogeny (such tectonism is widespread throughout the northeastern Atlantic, including the Bay of Biscay; Boillot et al., 1979; Montadert et al., 1979); and (3) erosion by bottom currents.

At the abyssal sites $(118,119,400$, and 550 ; all depositional depths $>3 \mathrm{~km}$ ), the major hiatus appears to be associated with the Eocene/Oligocene boundary (Fig. 17) and thus related to the abyssal circulation event noted by Miller and Tucholke (1983). Again, this hiatus may be partially the result of Eocene-Oligocene tectonism. However, Miller and Tucholke (1983) note the development of a similar latest Eocene to early Oligocene hiatus in the Rockall Plateau region, correlated this hiatus with Reflector R4, and argued that the hiatus resulted from a major circulation change.

The shallower, middle Oligocene erosional event postdated the deeper erosional event. If the record at 1 to 2 $\mathrm{km}$ (depositional depth) reflects eustatic sea level (e.g., Poag et al., this vol.), then there was no causal link of eustacy with the current-controlled event. This agrees with the suggestion of Tucholke (1981) that there may be no consistent causal link between sea-level change and the development of unconformities in the deep sea. Recently acquired data from the continental slope of the U.S.A. supports the idea that the deep-sea circulation event, denoted by Horizon $\mathrm{A}^{\mathrm{u}}$, predates the major sealevel lowering denoted by canyon-cutting along the continental margin (G. S. Mountain and B. E. Tucholke, pers. comm., 1982). In view of this, we present a scenario that could explain the development of late Paleogene hiatuses: (1) a latest Eocene to earliest Oligocene hiatus developed in the deep North Atlantic in response to a bottom-water event; (2) at intermediate depths, middle Oligocene deposition was discontinuous because of possible sea-level effects (Vail et al., 1977).

\section{Paleoceanographic Synthesis}

Site 549 is the first North Atlantic DSDP site where coring yielded continuous recovery of well-dated upper Eocene through lower Oligocene sediments, apparently unaltered by diagenetic or dissolution effects. This allows a detailed comparison of the benthic foraminiferal assemblage and isotopic records and the interpretation of these records in light of the development of North 
Atlantic abyssal circulation. Although the middle Oligocene record was poorly recovered on Leg 80 , we have used evidence for middle Oligocene abyssal circulation changes from Sites 119 and 400 (for a full discussion of these data, see Miller and Curry, 1982, and Miller, 1983) and from the abyssal circulation model of Miller and Tucholke (1983).

Figure 17 shows a summary of development of abyssal circulation, and demonstrates that the evolution of the Oligocene ocean from the Eocene ocean was not a rapid event as suggested by Kennett and Shackleton (1976). The major faunal and isotopic events spanned $\sim 4 \mathrm{~m}$.y. Nevertheless, there is some evidence that these "gradual" (Corliss, 1979b, 1981) or "sequential" (Tjalsma and Lohmann, 1983) changes were punctuated by a geologically rapid event, as suggested by Kennett and Shackleton (1976). Although the overall ${ }^{18} \mathrm{O}$ enrichment occurred in an approximately 2-m.y. interval (assuming constant sediment accumulation rates, Figs. 2 and 3), the early Oligocene $0.7 \% 0{ }^{18} \mathrm{O}$ and $0.6 \% 0{ }^{13} \mathrm{C}$ enrichments occurred in an interval of $<0.5$ m.y. This agrees well with the estimates for the duration of the $\delta^{18} \mathrm{O}$ change previously noted by Kennett and Shackleton (1976) and Keigwin (1980).

The major change in abyssal circulation inferred from the seismic record apparently postdates the first faunal and isotopic changes. We suggest this scenario for the data in Figure 17: (1) a series of hydrographic changes, which may represent the first influence of Arctic and/or Norwegian-Greenland Sea water on the deep North Atlantic, began by the late Eocene; (2) these changes cuiminated in a major temperature drop, decrease in age of bottom water, and a strong increase in intensity of circulation near the Eocene/Oligocene boundary; and (3) subsequently in the middle Oligocene, the general intensity of abyssal circulation decreased, and bottom waters became older and more corrosive again.

\section{CONCLUSIONS}

1. Major benthic foraminiferal changes occurred at Site 549 in the late Eocene to early Oligocene:

A. A Nuttallides truempyi-dominated assemblage was replaced in the early late Eocene ( 38.5-40 m.y. ago).

B. The succeeding buliminid assemblage was replaced by an assemblage dominated by stratigraphically long-ranging and bathymetrically wide-ranging taxa just below the Eocene/Oligocene boundary ( 37.5 m.y. ago).

C. In addition to these abundance changes, a series of last appearances occurred in the late Eocene, and a series of first appearances occurred in the late Eocene to earliest Oligocene.

2. Isotopic results from Site 549 show that

A. A $\delta^{13} \mathrm{C}$ increase of $\sim 0.6 \%$ correlates with the replacement of $N$. truempyi.

B. A major $\delta^{18} \mathrm{O}$ increase began $\sim 38$ m.y. ago (late Eocene), culminating in a rapid $(<0.5-$ m.y.) increase in $\delta^{18} \mathrm{O}$ just above the Eocene/Oligocene boundary $\left(\sim 36.5\right.$ m.y. ago). A rapid $\delta^{13} \mathrm{C}$ increase correlates with this latter $\delta^{18} \mathrm{O}$ increase.
3. Faunal results from Site 548 show that an assemblage dominated by $N$. truempyi and Lenticulina spp. was also replaced between the middle Eocene and the late Eocene by an assemblage dominated by a Gyroidinoides-Bulimina alazanensis-Globocassidulina subglobosa assemblage. The timing of this faunal change is more obscure owing to numerous hiatuses present at this site.

4. The Leg 80 data are combined with faunal and isotopic data from Legs 12 and 48, and with an abyssal circulation history derived from seismic stratigraphic studies of the Labrador Sea and the Rockall region in the following scenario:

A. Old, warm, corrosive, and sluggishly circulating bottom water was replaced by younger, colder, and more vigorously circulating bottom water, which had a northern source (Arctic and/or Norwegian-Greenland Sea). This developed throughout the late Eocene (40-37 m.y. ago), but was punctuated by a rapid event just above the Eocene/Oligocene boundary ( $\sim 36.5 \mathrm{~m}$.y. ago).

B. During the middle Oligocene, bottom-water circulation was reduced, and the age and corrosiveness of bottom water increased.

5. On the basis of the sediment distribution in the Bay of Biscay and the Rockall region, we suggest that

A. A latest Eocene to earliest Oligocene hiatus developed in the deep North Atlantic in response to a bottom-water event.

B. At intermediate depths, middle Oligocene deposition was discontinuous owing to sea-level effects.

Although the scenarios for the development of abyssal circulation and hiatuses are far from completely developed or correct in detail, they account for the lithostratigraphic, seismic stratigraphic, biostratigraphic, and isotopic data that must be considered in paleoceanographic studies.

\section{ACKNOWLEDGMENTS}

We thank W. A. Berggren, D. A. Johnson, L. D. Keigwin, R. C. Tjalsma, and B. E. Tucholke for critically reviewing the manuscript; R. C. Tjalsma, G. P. Lohmann, B. E. Tucholke, C. W. Poag, W. A. Berggren, P. E. Belanger, S. Snyder, and L. D. Keigwin for valuable discussions; M.-P. Aubry for providing calcareous nannofossil age assignments for the samples in this study; W. A. Berggren for providing advice on planktonic foraminiferal identifications and zonations; $\mathrm{P}$. C. Hartley for drafting the figures; and J. Commeau for producing the SEM micrographs. We also thank P. C. de Graciansky and C. W. Poag for access to Leg 80 material, and the shipboard party for cooperation in providing data in advance of its publication. This research was supported by the United States Navy, Office of Naval Research, under contract N00014-79-C-0071; by a graduate fellowship from Phillips Petroleum to K.G.M.; and by NSF Grants OCE $80-24608$ and OCE $82-151$ to W.B.C. The study of Tertiary bathyal benthic foraminifers at Woods Hole Oceanographic Institution is supported by a consortium of oil companies (ARCO, BP, Chevron, Cities Service, Elf-Aquitaine, Exxon, Gulf, Mobil, Phillips, Shell (International), Shell (USA), SOHIO, Texaco, and Union). This is Woods Hole Oceanographic Institution contribution number 5195 .

\section{REFERENCES}

Belanger, P. E., Curry, W. B., and Matthews, R. K., 1981. Core-top evaluation of benthic foraminiferal isotopic ratios for paleo-oceanographic interpretations. Palaeogeogr., Palaeoclimatol., Palaeoecol., 33:205-220. 
Benson, R. H., 1975. The origin of the psychrosphere as recorded in changes of deep-sea ostracode assemblages. Lethaia, 8:69-83.

Berger, W. H., and Winterer, E. L., 1974. Plate stratigraphy and the fluctuating carbonate line. In Hsü, K. J., and Jenkyns, H. C. (Eds.), Pelagic Sediments on Land and Under the Sea: London (Blackwell Sci. Pubs., Int. Assoc. Sed.), Spec. Publ., 1:11-48.

Berggren, W. A., 1971. Multiple phyletic zonations of the Cenozoic based upon planktonic foraminifera. In Farinacci, A. (Ed.), Proc. Second Planktonic Conf:: Rome (Tecnoscienza), pp. 41-50.

1972a. Cenozoic biostratigraphy and paleobiogeography of the North Atlantic. In Laughton, A. S., Berggren, W. A., et al., Init. Repts. DSDP, 12: Washington (U.S. Govt. Printing Office), 965-1001.

1972b. A Cenozoic time scale: some implications for regional geology and paleobiogeography. Lethaia, 5:195-215.

Berggren, W. A., and Aubert, J., 1976. Late Paleogene (late Eocene and Oligocene) benthonic foraminiferal biostratigraphy and paleobathymetry of Rockall Bank and Hatton-Rockall Basin. Micropaleontology, 22:307-326.

Berggren, W. A., and Schnitker, D., 1983. Cenozoic marine environments in the North Atlantic and Norwegian-Greenland Sea. In Bott, M., Saxov, S., Talwani, M., and Thiede, J. (Eds.), Structure and Development of the Greenland-Scotland Ridge, NATO Advanced Research Institute, Bressanone, Italy, May 11-16, 1981: New York (Plenum Press).

Blanc, P.-L., Rabussier, D., Vergnaud Grazzini, C., and Duplessy, J. C., 1980. North Atlantic Deep Water formed by the later middle Miocene. Nature, 283:553-555.

Blow, W. H. 1969. Late middle Eocene to Recent planktonic foraminiferal biostratigraphy. In Brönnimann, P., and Renz, H. H. (Eds.), Proc. First Internat. Conf. Planktonic Microfossils: Leiden (E. J. Brill), pp. 199-422.

1979. The Cainozoic Globigerinida: London (E. J. Brill).

Boersma, A., 1977. Eocene to early Miocene benthic foraminifera DSDP Leg 39, South Atlantic. In Supko, P. R., Perch-Nielsen, K., et al., Init. Repts. DSDP, 39: Washington (U.S. Govt. Printing Office), 643-656.

Boersma, A., and Shackleton, N., 1977. Tertiary oxygen and carbon isotope stratigraphy, Site 357 (mid-latitude South Atlantic). In Supko, P. R., Perch-Nielsen, K., et al., Init. Repts. DSDP, 39: Washington (U.S. Govt. Printing Office), 911-924.

Boillot, G., Auxietre, J., Dunand, J., Dupeuble, P., and Mauffret, A., 1979. The northwest Iberian margin: a Cretaceous passive margin deformed during the Eocene. In Talwani, M., Hay, W., and Ryan, W. B. F. (Eds.), Deep Drilling in the Atlantic Ocean: Continental Margins and Paleoenvironment: Washington (Am. Geophys. Union), Maurice Ewing Series, 3:138-153.

Bolli, H. M., 1957a. The genera Globigerina and Globorotalia in the Paleocene-Lower Eocene Lizard Springs Formation of Trinidad, B.W.I. U.S. Nat. Mus. Bull., 215:61-81.

1957b. Planktonic foraminifera from the Eocene Navet and San Fernando formations of Trinidad, B.W.I. U.S. Nat. Mus. Bull., 215:155-172.

1966. Zonation of Cretaceous to Pliocene marine sediments based upon planktonic foraminifera. Bol. Inform. Assoc. Venez. Geol. Min. Petrol., 9:988-1011.

Boltovskoy, E., 1980. On the benthonic bathyal-zone foraminifera as stratigraphic guide fossils. J. Foram. Res., 10:163-172.

Bremer, M. L., and Lohmann. G. P., 1982. Evidence for primary control of the distribution of certain Atlantic Ocean benthonic foraminifera by degree of carbonate saturation. Deep-Sea Res., 29: 987-998.

Broecker, W. S., 1982. Ocean chemistry during glacial time. Geochim. Cosmochim. Acta, 46:1689-1705.

Cordey, W. G., Berggren, W. G., and Olsson, R. K., 1970. Phylogenetic trends in the planktonic foraminiferal genus Pseudohastigerina Banner and Blow, 1959. Micropaleontology, 16:235-242.

Corliss, B. H., 1979a. Quaternary Antarctic Bottom Water history: benthonic foraminiferal evidence from the southeast Indian Ocean. Quat. Res., 12:271-289.

$1979 \mathrm{~b}$. Response of deep-sea benthonic foraminifera to development of the psychrosphere near the Eocene/Oligocene boundary. Nature, 282:63-65.

1981. Deep-sea benthonic foraminiferal faunal turnover near the Eocene/Oligocene boundary. Mar. Micropaleontol., 6:367-384.
Douglas, R. G., 1973. Benthonic foraminiferal biostratigraphy in the central North Pacific, Leg 17, Deep Sea Drilling Project. In Winterer, E. L., Ewing, J. L., et al., Init. Repts. DSDP, 17: Washington (U.S. Govt. Printing Office), 607-671.

Douglas, R. G., and Woodruff, F., 1982. Deep-sea benthic foraminifera. In Emiliani, C. (Ed.), The Sea (Vol. 7): New York (Wiley-Interscience), pp. 1233-1327.

Ducasse, O., and Peypouquet, J. P., 1979. Cenozoic ostracodes: their importance for bathymetry, hydrology, and biogeography. In Montadert, L., Roberts, D. G., et al., Init. Repts. DSDP, 48: Washington (U.S. Govt. Printing Office), 343-363.

Duplessy, J. C., Moyes, J., and Pujol, C., 1980. Deep water formation in the North Atlantic Ocean during the last ice age. Nature, 286: 479-482.

Epstein, S., Buchsbaum, R., Lowenstam, H. A., and Urey, H. C., 1953. Revised carbonate-water isotopic temperature scale. Geol. Soc. Am. Bull., 64:1315-1325.

Glass, B. P., and Crosbie, J. R., 1982. Age of the Eocene/Oligocene boundary based upon extrapolation from North American microtektite layer. Am. Assoc. Petrol. Geol. Bull., 66:471-475.

Graham, D. W., Corliss, B. H., Bender, M. L., and Keigwin, L. D., 1981. Carbon and oxygen isotopic disequilibria of Recent benthic foraminifera. Mar. Micropaleontol., 6:483-497.

Haq, B. U., 1981. Paleogene paleoceanography: early Cenozoic oceans . revisited. Proc. 26th Int. Geol. Congr., Geol. Oceans Symp., pp. 71-82.

Hardenbol, J., and Berggren, W. A., 1978. A new Paleogene numerical time scale. Stud. Geol. (Tulsa, Okla.), 6:213-234.

Jones, E. J., Ewing, M., Ewing, J. I., and Eittreim, S. L., 1970. Influences of Norwegian Sea overflow on sedimentation in the northern North Atlantic and the Labrador Sea. J. Geophys. Res., 75: $1655-1680$.

Karig, D. E., Ingle, J. C., et al., 1975. Init. Repts. DSDP, 31: Washington (U.S. Govt. Printing Office).

Keigwin, L. D., 1980. Palaeoceanographic change in the Pacific at the Eocene-Oligocene boundary. Nature, 287:722-725.

Kennett, J. P., Houtz, R. E., et al. 1975. Init. Repts. DSDP, 29: Washington (U.S. Govt. Printing Office).

Kennett, J. P., and Shackleton, N. J., 1976. Oxygen isotope evidence for the development of the psychrosphere $38 \mathrm{Myr}$ ago. Nature, 260:513-515.

Kerr, R. A., 1982. New evidence fuels Antarctic ice debate. Science, 216:973-974.

Krasheninnikov, V. A., 1979. Stratigraphy and planktonic foraminiferas of Cenozoic deposits of the Bay of Biscay and Rockall Plateau, DSDP Leg 48. In Montadert, L., Roberts, D. G., et al., Init. Repts. DSDP, 48: Washington (U.S. Govt. Printing Office), 431-450.

Kroopnick, P., 1974. Correlation between ${ }^{13} \mathrm{C}$ and $\mathrm{CO}_{2}$ in surface waters and atmospheric $\mathrm{CO}_{2}$. Earth Planet. Sci. Lett., 22:397-403. 1980. The distribution of ${ }^{13} \mathrm{C}$ in the Atlantic Ocean. Earth Planet. Sci. Lett., 49:469-484.

Kroopnick, P., Weiss, R. F., and Craig, H., 1972. Total $\mathrm{CO}_{2},{ }^{13} \mathrm{C}$, and dissolved oxygen- ${ }^{18} \mathrm{O}$ at Geosecs II in the North Atlantic. Earth Planet. Sci. Lett., 16:103-110.

Lohmann, G. P., 1978. Abyssal benthonic foraminifera as hydrographic indicators in the western South Atlantic Ocean. J. Foram. Res., 8: 6-34.

1980. PATS-1, a package of programs for the analysis of marine micropaleontological data on the VAX 11/780 computer. Woods Hole Oceanographic Institution Tech. Rep., WHOI-80-27.

Lohmann, G. P., and Carlson, J. J., 1981. Oceanographic significance of Pacific late Miocene calcareous nannoplankton. Mar. Micropaleontol., 6:553-579.

Matthews, R. K., and Poore, R. Z., 1980. Tertiary $\delta^{18} \mathrm{O}$ record and glacio-eustatic sea-level fluctuations. Geology, 8:501-504.

Miller, K. G., 1982. Late Paleogene (Eocene to Oligocene) paleoceanography of the northern North Atlantic [Ph.D. dissert.]. MIT/ WHOI Joint Program in Oceanography.

1983. Late Paleogene paleoceanography of the Bay of Biscay: benthic foraminiferal evidence. Mar. Micropalentol., 7: 403-440.

Miller, K. G., and Curry, W. B., 1982. Eocene to Oligocene benthic foraminiferal isotopic record in the Bay of Biscay. Nature, 296: 347-350. 
Miller, K. G., and Tucholke, B. E., 1983. Development of Cenozoic abyssal circulation south of the Greenland-Scotland Ridge. In Bott, M., Saxov, S., Talwani, M., and Thiede, J. (Eds.), Structure and Development of the Greenland-Scotland Ridge, NATO Advanced Research Institute, Bressanone, Italy, May 11-16, 1981: New York (Plenum Press), pp. 549-589.

Montadert, L., Roberts, D., de Charpal, O., Guennoc, P., and Sibuet, J., 1979. Northeast Atlantic passive continental margins: rifting and subsidence processes. In Talwani, M., Hay, W., and Ryan, W. B. F., Deep Drilling in the Atlantic Ocean: Continental Margins and Paleoenvironment: Washington (Am. Geophys. Union), Maurice Ewing Series, 3:154-186.

Moore, T. C., van Andel, T. H., Sancetta, C., and Pisias, N., 1978. Cenozoic hiatuses in pelagic sediments. Micropaleontology, 24: 113-138.

Müller, C., 1979. Calcareous microfossils from the North Atlantic (Leg 48). In Montadert, L., Roberts, D. G., et al., Init. Repts. DSDP, 48: Washington (U.S. Govt. Printing Office), 589-640.

Odin, G. S., 1978. Isotopic dates for a Paleogene time scale. Stud. Geol. (Tulsa, Okla.), 6:247-257.

Odin, G. S., Curry, D., and Hunziker, J. C., 1978. Radiometric dates from the NW European glauconites and the Paleogene time scale. J. Geol. Soc. London, 135:481-497.

Olsson, R. K., Miller, K. G., and Ungrady, T. E., 1980. Late Oligocene transgression of middle Atlantic Coastal Plain. Geology, 8: 549-554.

Parsons, B., and Sclater, J. G., 1977. An analysis of the variation of ocean floor bathymetry and heat flow with age. J. Geophys. Res., 82:803-827.

Proto-Decima, F., and Bolli, H. M., 1978. Southeast Atlantic Leg 40 Paleogene benthic foraminifers. In Bolli, H. M., Ryan, W. B. F., et al., Init. Repts. DSDP, 40: Washington (U.S. Govt. Printing Office), 783-809.

Resig, J. M., 1976. Benthic foraminiferal stratigraphy, eastern margin, Nazca Plate. In Yeats, R. S., Hart, S. R., et al., Init. Repts. DSDP, 34: Washington (U.S. Govt. Printing Office), 743-759.

Roberts, D. G., 1975. Marine geology of the Rockall Plateau and Trough. Philos. Trans. R. Soc. London, Ser. A, 278:447-509.

Ruddiman, W. F., 1972. Sediment redistribution on the Reykjanes Ridge: seismic evidence. Geol. Soc. Am. Bull., 83:2039-2062.

Savin, S. M., 1977. The history of the Earth's surface temperature during the past 100 million years. Ann. Rev. Earth Planet. Sci., 5: 319-355.

Savin, S. M., Douglas, R. G., and Stehli, F. G., 1975. Tertiary marine paleotemperatures. Geol. Soc. Am. Bull., 86:1499-1510.

Schnitker, D., 1974. Western Atlantic abyssal circulation during the past 120,000 years. Nature, 248:385-387.

1979. Cenozoic deep water benthic foraminifera, Bay of Biscay. In Montadert, L., Roberts, D. G., et al., Init. Repts. DSDP, 48: Washington (U.S. Govt. Printing Office), 377-413.

1980a. Global paleoceanography and its deep water linkage to the Antarctic glaciation. Earth Sci. Rev., 16:1-20.

$1980 \mathrm{~b}$. North Atlantic oceanography as a possible cause of Antarctic glaciation and eutrophication. Nature, 284:615-616.

Sclater, J. G., Abbott, D., and Thiede, J., 1977. Paleobathymetry and sediments of the Indian Ocean. In Heirtzler, J. R., Bolli, H. M., and Davies, T. A. (Eds.), Indian Ocean Geology and Biostratigraphy: Washington (Am. Geophys. Union), pp. 25-59.

Sclater, J. G., Anderson, R. N., and Bell, N. L., 1971. Elevation of ridges and evolution of the central eastern Pacific. J. Geophys. Res., 76:7888-7915.

Shackleton, N. J., 1977. Carbon-13 in Uvigerina: tropical rain forest history and the Equatorial Pacific carbonate dissolution cycles. In Anderson, N. R., and Malahoff, A. (Eds.), The Fate of Fossil Fuel $\mathrm{CO}_{2}$ in the Oceans: New York (Plenum Press), pp. 401-427.
Shackleton, N. J., and Kennett, J. P., 1975. Paleotemperature history of the Cenozoic and the initiation of Antarctic glaciation: oxygen and carbon isotope analyses in DSDP Sites 277, 279, and 281. In Kennett, J. P., Houtz, R. E., et al., Init. Repts. DSDP, 29: Washington (U.S. Govt. Printing Office), 743-755.

Shackleton, N. J., and Opdyke, N. D., 1973. Oxygen isotope and palaeomagnetic stratigraphy of Equatorial Pacific core V28-238: oxygen isotope temperatures and ice volume on a $10^{5}$ and $10^{6}$ year scale. Quat. Res., 3:39-55.

Stainforth, R. M., Lamb, J. L., Luterbacher, H., Beard, J. H., and Jeffords, R. M., 1975. Cenozoic planktonic foraminiferal zonation and characteristics of index fossils. Univ. Kansas Paleont. Contrib., 62 .

Streeter, S. S., 1973. Bottom water and benthonic foraminifera in the North Atlantic: glacial-interglacial contrasts. Quat. Res., 3:131-141.

Tjalsma, R. C., 1982. What happens to deep-sea benthic foraminifera near the Eocene/Oligocene boundary. IGCP Proj. 174 Field Conf. (Baton Rouge).

Tjalsma, R. C., and Lohmann, G. P., 1983. Paleocene-Eocene bathyal and abyssal benthic foraminifera from the Atlantic Ocean. Micropaleontol., Spec. Publ., 4.

Toumarkine, M., and Bolli, H. M., 1970. Évolution de Globorotalia cerrazulensis (Cole) dans l'Éocène moyen et supérieur de Possagno (Italie). Rev. Micropaleontol., 13:131-145.

1975. Foraminifères planctoniques de l'Éocène moyen et supérieur de la Coupe de Possagno. Schweiz. Palaontol. Abh., 97: 69-83, 173-185.

Tucholke, B. E., 1981. Geological significance of seismic reflectors in the deep western North Atlantic. In Warme, J. E., Douglass, R. G., and Winterer, E. L. (Eds.), The Deep Sea Drilling Project: A Decade of Progress. Soc. Econ. Paleontol. Mineral. Spec. Publ., 32:23-38.

Tucholke, B. E., and Vogt, P. R., 1979. Western North Atlantic: sedimentary evolution and aspects of tectonic history. In Tucholke, B. E., Vogt, P. R., et al., Init. Repts. DSDP, 43: Washington (U.S. Govt. Printing Office), 791-825.

Vail, P. R., Mitchum, R. M., Jr., Todd, R. G., Widmier, J. M., Thompson, S. III, Sangree, J. B., Bubb, J. N., and Hatlelid, W. G., 1977. Seismic stratigraphy and global changes of sea level. In Payton, C. E. (Ed.), Seismic Stratigraphy-Applications to Hydrocarbon Exploration. Am. Assoc. Petrol. Geol. Mem., 26:49-205.

Van Couvering, J. A., Aubry, M.-P., Berggren, W. A., Bujak, J. P., Maeser, C. D., and Wieser, T., 1981. The terminal Eocene event and the Polish connection. Palaeogeogr., Palaeoclimatol., Palaeoecol., 36:321-362.

Vergnaud Grazzini, C., 1979. Cenozoic paleotemperatures at Site 398, eastern North Atlantic: diagenetic effects on carbon and oxygen isotopic signal. In Sibuet, J.-C., Ryan, W. B. F., et al., Init. Repts. DSDP, 47, Pt. 2: Washington (U.S. Govt. Printing Office), 507-511.

Vergnaud Grazzini, C., Müller, C., Pierre, C., Létolle, R., and Peypouquet, J. P., 1979. Stable isotopes and Tertiary paleontological paleoceanography in the northeast Atlantic. In Montadert, L., Roberts, D. G., et al., Init. Repts. DSDP, 48: Washington (U.S. Govt. Printing Office), 475-491.

Vergnaud Grazzini, C., Pierre, C., and Létolle, R., 1978. Paleoenvironment of the northeast Atlantic during the Cenozoic: oxygen and carbon isotope analyses of DSDP Sites 398, 400A, and 401 . Oceanol. Acta, 11:381-390.

Woodruff, F., Savin, S. M., and Douglas, R. G., 1980. Biological fractionation of oxygen and carbon isotopes by Recent benthic foraminifera. Mar. Micropaleontol., 5:3-13.

Date of Initial Receipt: December 6, 1982

Date of Acceptance: July 6, 1983 


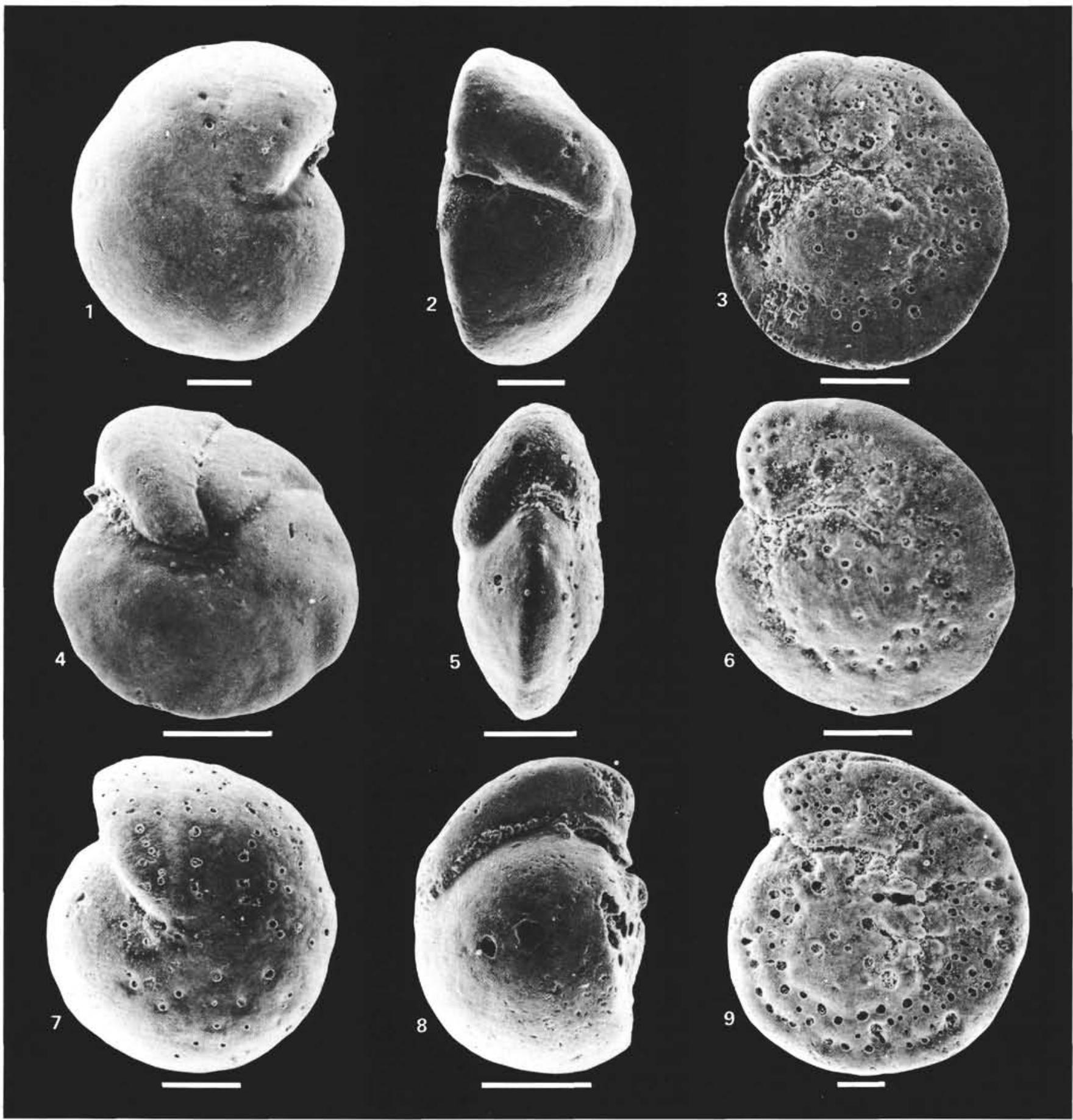

Plate 1. Cibicidoides spp., Site 549. (Scale bars $=100 \mu \mathrm{m}$.) 1-3.Cibicidoides iuxpamensis, (1) Sample 549A-17-2, 43-35 cm, (2) Sample 549A-13-1, 143-148 cm, (3) Sample 549A-24-2, 126-130 cm. 4-6. Cibicidoides ungerianus, Sample 549A-10-6, 143-148 cm. 7-9. Cibicidoides grimsdalei, (7) Sample 549A-35-1, 26-28 cm, (8) Sample 549A-33-1, 143-146 cm, (9) Sample 549A-33-1, 143-146 cm. 


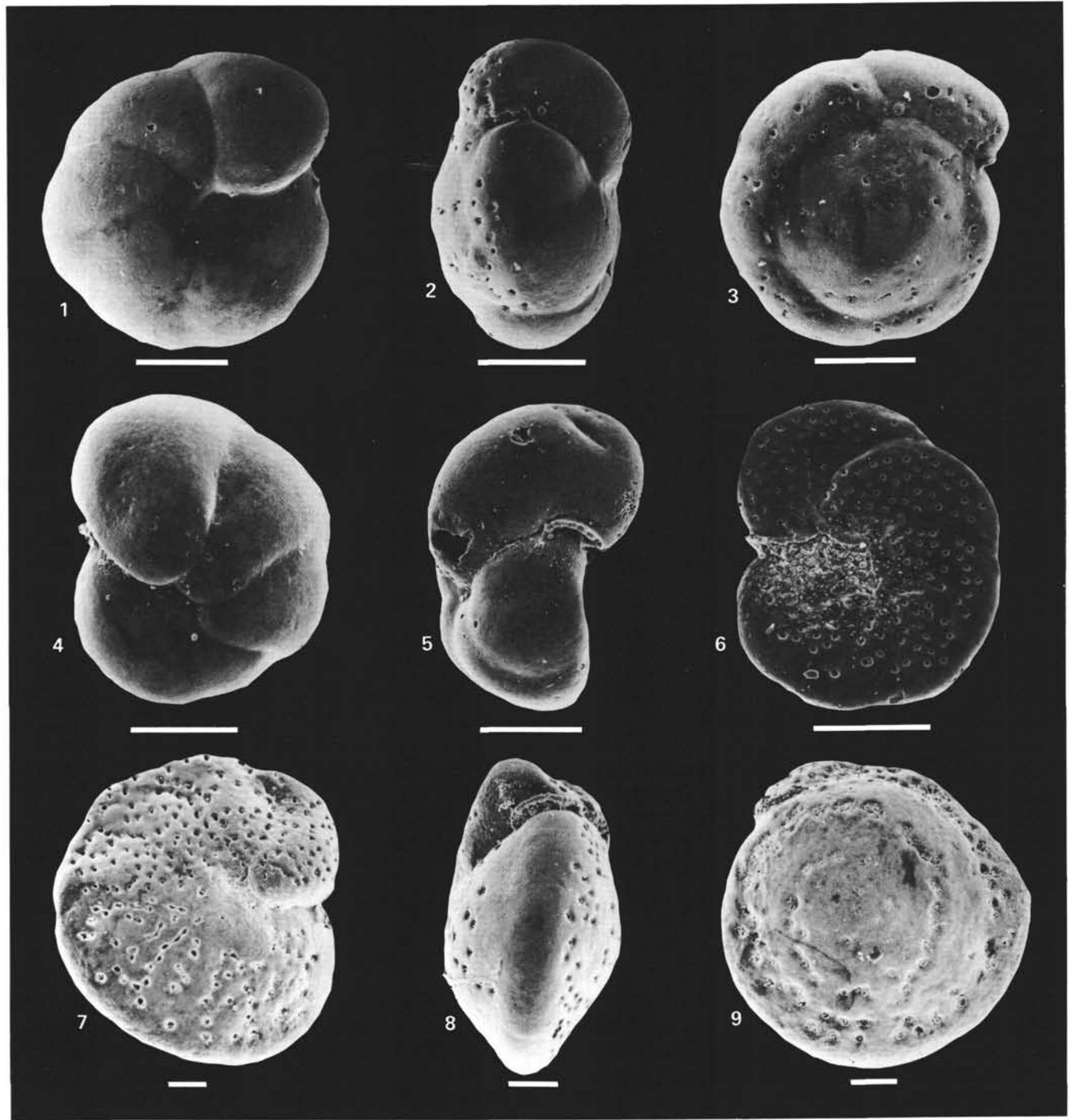

Plate 2. Cibicidoides spp., Site 549. (Scale bars $=100 \mu \mathrm{m}$.) 1-3. Cibicidoides haitiensis, Sample 549A-14-1, 116-121 cm. 4-6. Cibicidoides laurisae, (4) Sample 549A-7-6, 118-123 cm, (5) Sample 549A-7-6, 118-123 cm, (6) Sample 549A-13-1, 143-148 cm. 7-9. Cibicidoides havanensis, (7) Sample 549A-13-1, 143-148 cm, (8) Sample 549A-14-1, 116-121 cm, (9) Sample 549A-14-1, 116-121 cm. 


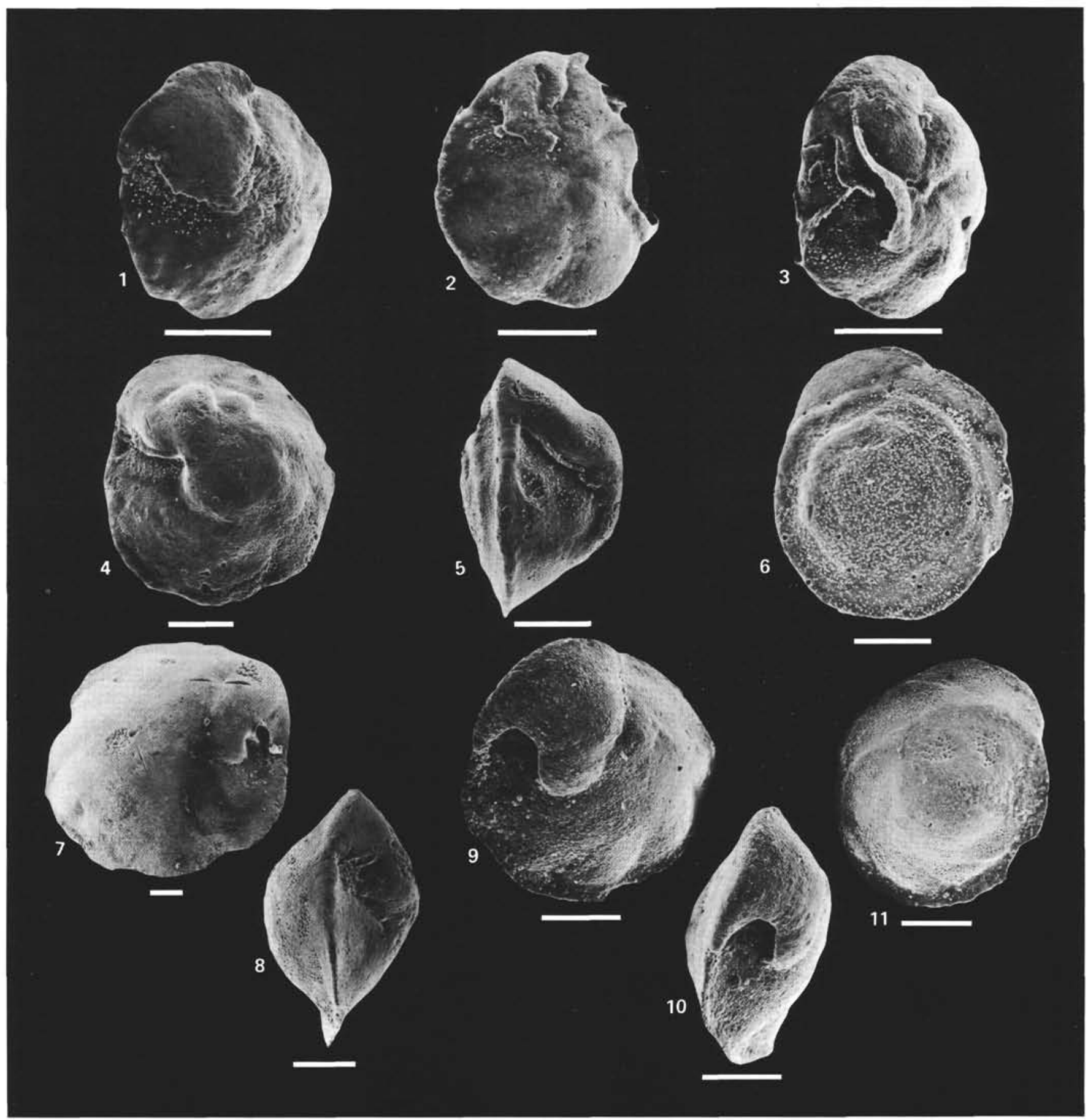

Plate 3. Nuttallides and Osangularia spp., Site 549. (Scale bars $=100 \mu \mathrm{m}$.) 1-2. Nuttallides umbonifera, (1) Sample 549A-7-6, 118-123 cm, (2) Sample 549A-33-1, 143-146 cm. 3. Nuttallides cf. umbonifera, Sample 549A-35-1, 26-28 cm. 4-6. Nuttallides truempyi, (4) Sample 549A-35-1, 26-28 cm, (5-6) Sample 549A-40-1, 94-97 cm. 7-8. Osangularia mexicana, Sample 549A-35-1, 26-28 cm. 9-11. Osangularia sp. 2, Sample 549A-24-2, 126-130 cm. 


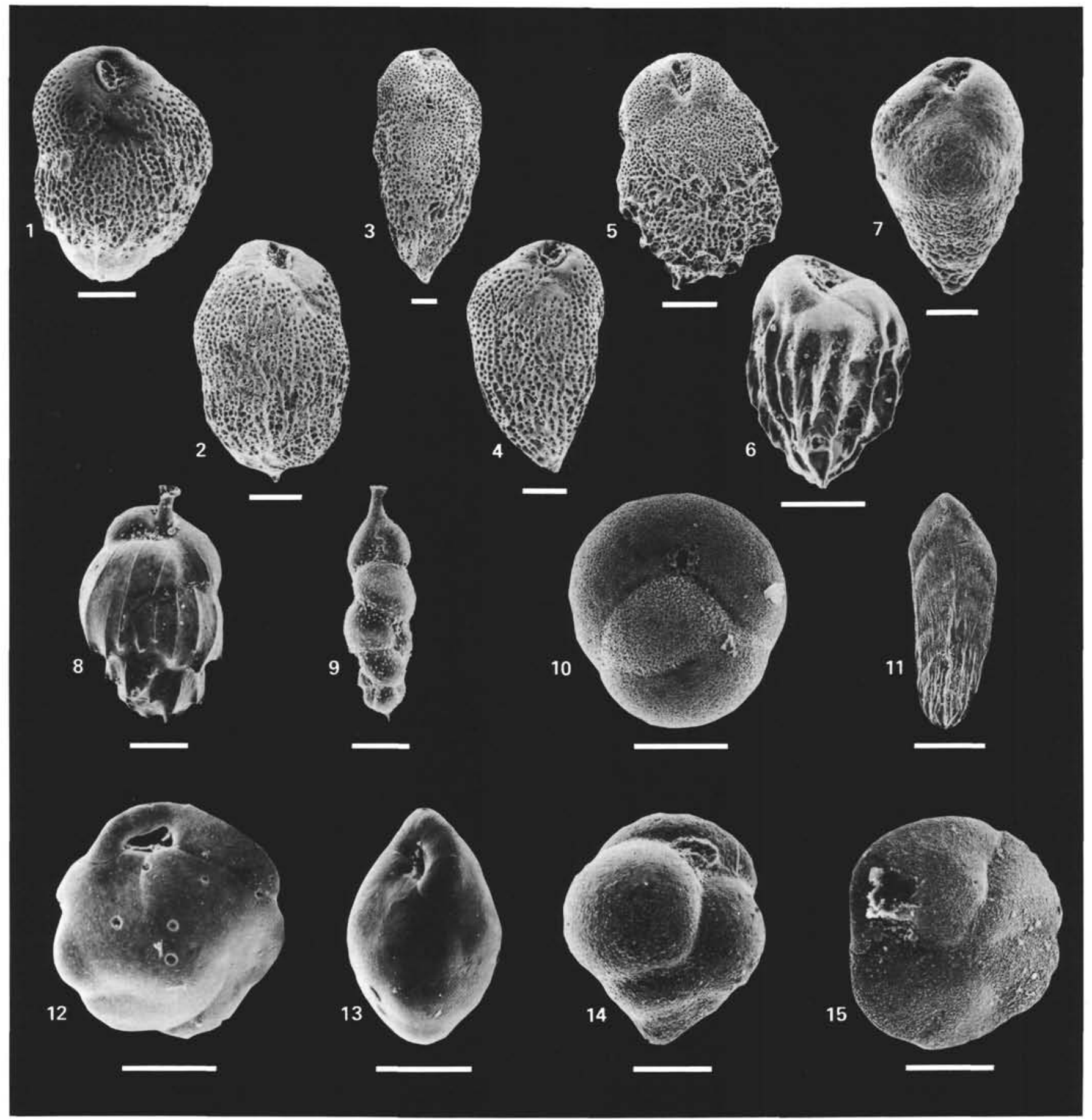

Plate 4. Buliminids and late Oligocene taxa, Site 549. (Scale bars $=100 \mu \mathrm{m}$.) 1. Bulimina glomarchallengeri, Sample 549A-28-1, 143-146 cm. 2. B. cf. semicostata, Sample $549 \mathrm{~A}-28-1,143-146 \mathrm{~cm}$. 3. B. jarvisi, Sample $549 \mathrm{~A}-28-1,143-146 \mathrm{~cm}$. 4. B. semicostata, Sample $549 \mathrm{~A}-28-1$, 143-146 cm. 5. B. trinitatensis, Sample 549A-33-1, 143-146 cm. 6. B. alazanensis, Sample 549A-16-2, 24-27 cm. 7. B. tuxpamensis, Sample 549-2-5, 126-129 cm. 8-9. Uvigerina spp., Sample 549A-6-6, 100-105 cm. 10. Sphaeroidina bulloides, Sample 549A-6-6, 100-105 cm. 11. Bolivina antegressa, Sample 549A-7-6, 118-123 cm. 12-13. Cassidulina havanesis, Sample 549A-7-6, 118-123 cm. 14. Eggerella bradyi, Sample 549A-7-6, 118-123 cm. 15. Epistominela exigua, Sample 549A-7-6, 118-123 cm. 


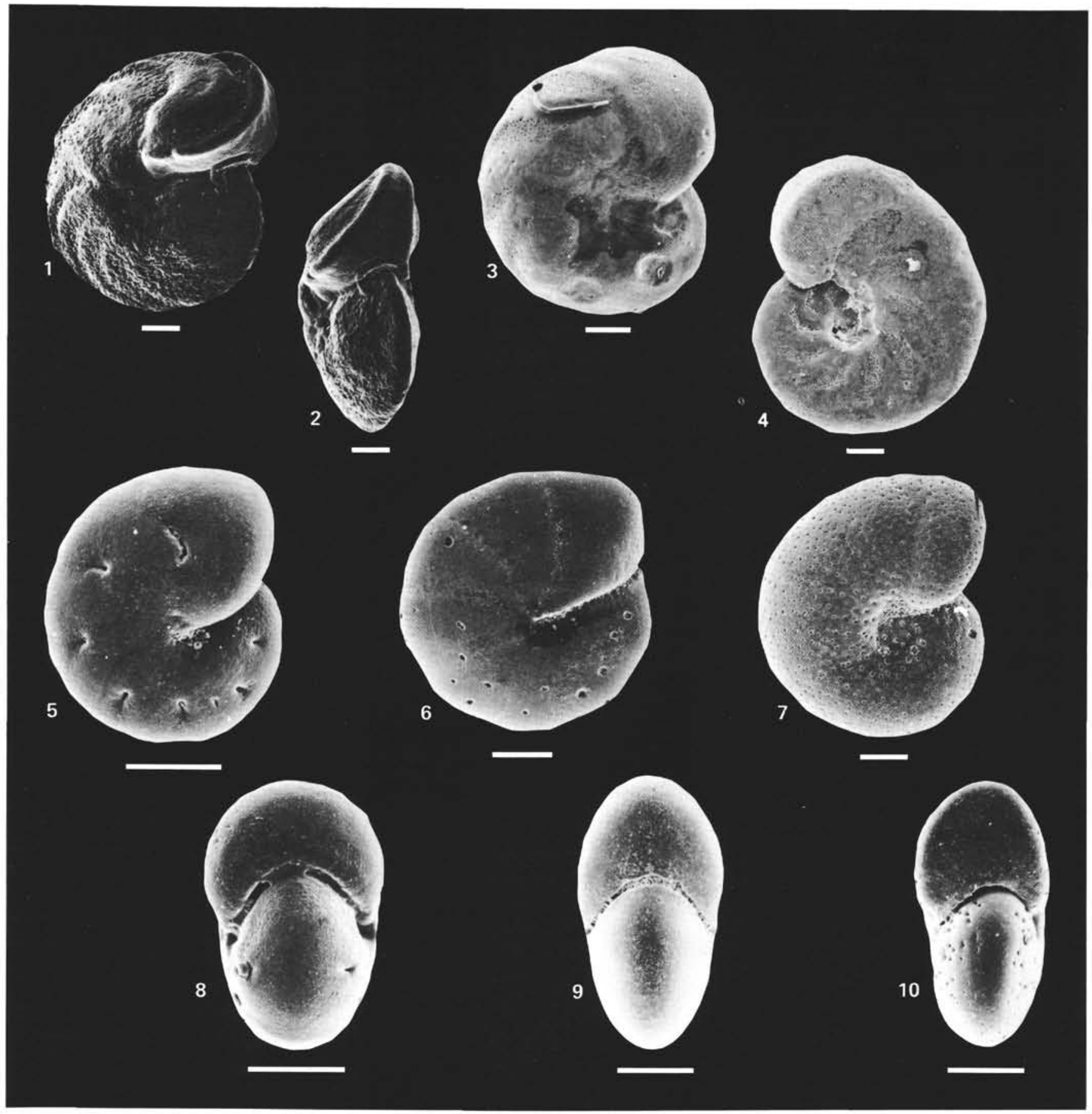

Plate 5. Oligocene taxa, Site 549. (Scale bars $=100 \mu \mathrm{m}$.) 1-2. Planulina sp. 6, Sample 549A-10-6, 143-148 cm. 3-4. Hanzawaia cushmani, Sample 549A-14-1, 116-121 cm. 5-6. Astrononion pusillum, Sample 549A-9-6, 70-75 cm. 7-8. Nonion havanense, Sample 549A-10-6, 143-148 cm. 9-10. Anomalina spissiformis, Sample 549A-16-1, 138-141 cm. 


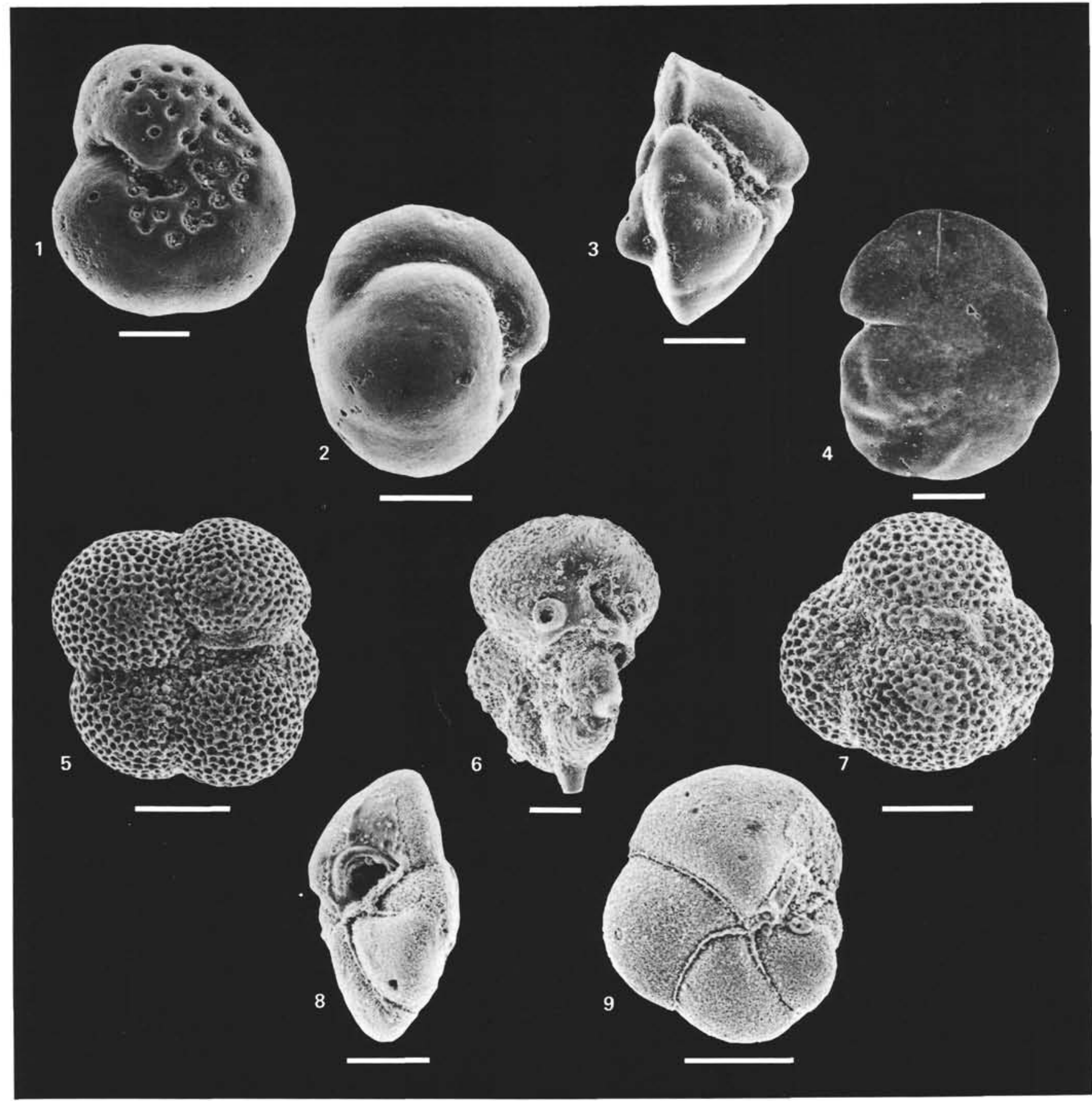

Plate 6. Miscellaneous benthic foraminifers and planktonic foraminifers, Site 549. (Scale bars $=100 \mu \mathrm{m}$.) 1-2. Gavelinella semicribrata, Sample 549A-33-1, 143-146 cm. 3-4. ? Gyroidinoides spp., Sample 549A-11-6, 143-148 cm. 5. Globorotalia opima opima, Sample 549A-10-6, 143-148 cm. 6. Cribrohantkenina sp., Sample $549 \mathrm{~A}-17-2,43-45 \mathrm{~cm}$. 7. Subbotina angiporoides, Sample 549A-10-6, 143-148 cm. 8-9. Globorotalia cerroazulensis cunialensis, Sample 549A-28-1, 143-146 cm. 


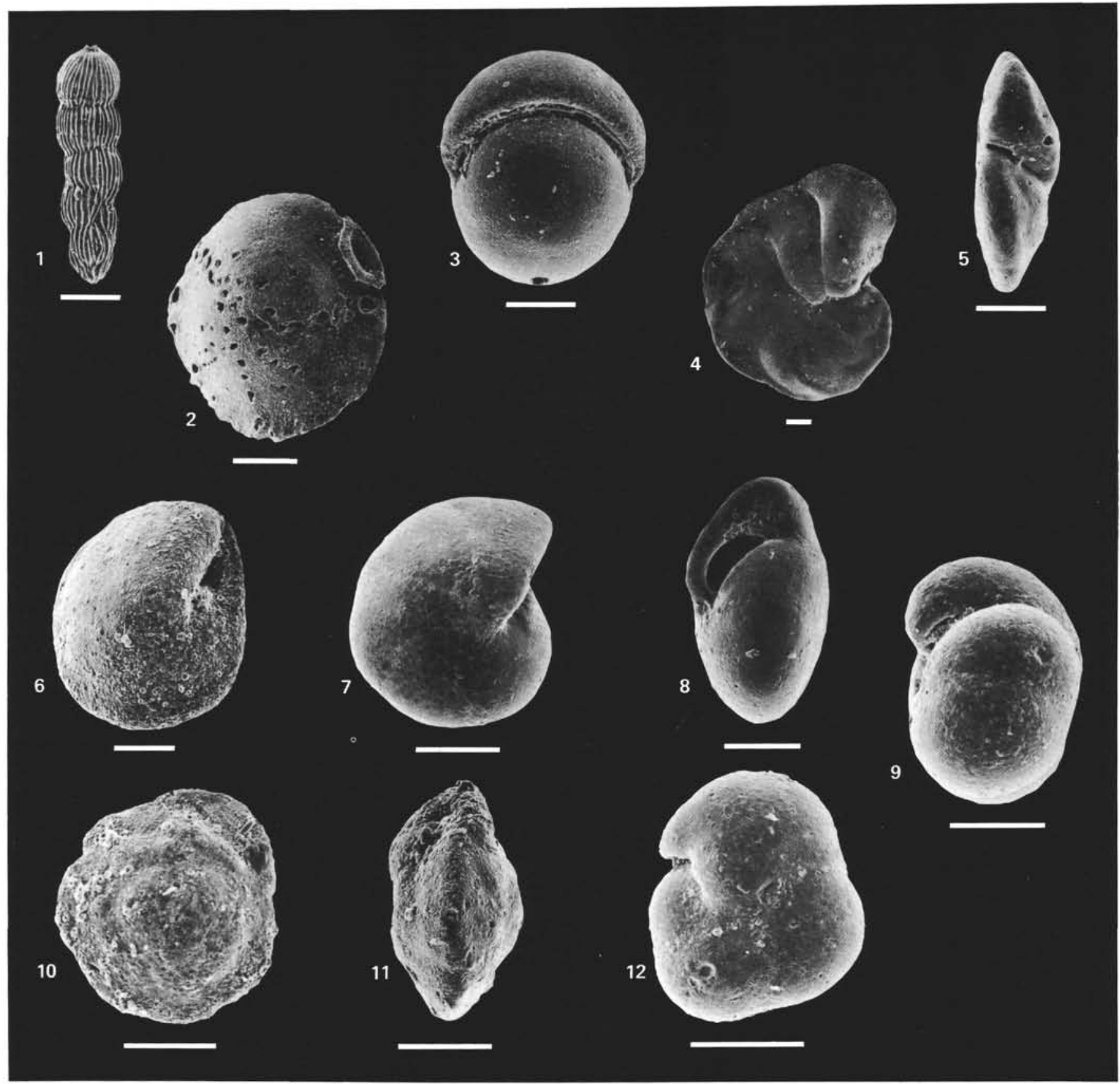

Plate 7. Top two rows: benthic foraminiferal taxa, Site 548. Bottom two rows: benthic foraminiferal taxa, Site 550 . (Scale bars $=100 \mu \mathrm{m}$.) $1-2$. From the Miocene, although they also occur in the upper Oligocene, (1) Rectouvigerina sp., Sample 548-15-2, 79-81 cm, (2) Siphonina tenuicarinata, Sample 548-15-2, 79-81 cm. 3. Pullenia bulloides, Sample 548-15-6, 52-56 cm. 4-5. Planulina sp. 5., Sample 548-15-6, 52-56 cm. 6. Alabamina dissonata, Sample 550-24-2, 144-149 cm. 7-8. Clinapertina inflata, Sample 550-24-5, 56-61 cm. 9. Abyssamina poagi, Sample 550-24,CC. 10-11. Nuttallides umbonifera, Sample 550-24-1, 74-78 cm. 12. Quadrimorphina profunda, Sample 550-24-4, 54-59 cm. 